\title{
Sequential Ru-Pd catalysis: A two-catalyst one-pot protocol for the synthesis of N- and O-heterocycles
}

\author{
Barry M. Trost,* Michelle R. Machacek, and Brian D. Faulk \\ Department of Chemistry, Stanford University, Stanford, CA 94305
}

\section{Experimental Section}

General Methods. All reactions were performed under an atmosphere of dry argon in flame-dried glassware unless otherwise indicated. Solvents were distilled under an atmosphere of argon before use and transferred via an oven dried syringe or cannula. Tetrahydrofuran, 1,2-dimethoxyethane, and 1,4-dioxane were distilled from sodium benzophenone ketal. Diisopropylamine, 1,2-dichloroethane, diisopropylethylamine, pyridine, triethylamine, and trimethylsilyl chloride were distilled from calcium hydride. Methanol was distilled from magnesium methoxide. Dichloromethane, diethylether, toluene, and acetonitrile were purified by an alumina column purification system. Bis[ $[\pi-$ allylpalladium chloride] was prepared by the procedure of Shaw. ${ }^{1}$ Tris(dibenzylideneacetone)dipalladium monochloroform complex, $\mathrm{Pd}_{2} \mathrm{dba}_{3} \mathrm{CHCl}_{3}$, was prepared by the known method of Ibers. ${ }^{2}$ Chiral ligands were prepared by the method of Trost. ${ }^{3}\left[\mathrm{CpRu}\left(\mathrm{CH}_{3} \mathrm{CN}\right)_{3}\right] \mathrm{PF}_{6}$ was prepared according to the method of Trost. ${ }^{4}$ All other reagents were obtained from Aldrich, Fluka, or Acros unless otherwise noted.

Flash chromatography was performed with EM Science silica gel (0.040-0.063 $\mu \mathrm{m}$ grade) according to the procedure of Still. ${ }^{5}$ Solvents for chromatography are listed as volume/volume ratios. Analytical thin layer chromatography was performed using $0.2 \mathrm{~mm}$ coated commercial silica gel plates (E. Merck, DC-Plastikfolien, Kiedelgel $60 \mathrm{~F}_{254}$ ). Melting points were obtained on a Thomas-Hoover apparatus in open capillary tubes and are uncorrected. Kugelrohr distillation was performed in a Buchi GKR-50 glass oven.

Infrared spectra were recorded on a Perkin Elmer Paragon 500 FT-IR spectophotometer using sodium chloride plates. Absorbance frequencies are recorded in reciprocal centimeters $\left(\mathrm{cm}^{-1}\right)$. Elemental analyses were performed by $\mathrm{M}-\mathrm{H}-\mathrm{W}$ Laboratories, Phoenix, Arizona. High resolution mass spectra (HRMS) were obtained from the Mass Spectrometry Resource, School of Pharmacy, University of California-San Francisco on a Kratos MS9 spectrometer. HRMS data are reported as m/e (relative intensity), with accurate mass reported for the molecular ion $\left(\mathrm{M}^{+}\right)$or suitable fragments.

Proton nuclear magnestic resonance $\left({ }^{1} \mathrm{H}\right.$ NMR) spectra were acquired at 300,400 , or $500 \mathrm{MHz}$ on a Varian Gemini spectrometer. Chemical shifts are reported in delta $(\delta)$ units in parts per million (ppm) relative to the singlet (7.24ppm) for chloroform- $d$. Splitting patterns are designated as s, singlet; d, doublet; t, triplet; q, quartet; $\mathrm{p}$, quintet; $\mathrm{m}$, multiplet; and br, broad. Coupling constants are recorded in Hertz (Hz). Carbon-13 nuclear magnetic resonance $\left({ }^{13} \mathrm{C}\right.$ NMR $)$ spectra were acquired at 75,99 , or $125 \mathrm{MHz}$ on a Varian Gemini spectrometer. Chemical shifts are reported in ppm relative to the central line of the triplet at $77.0 \mathrm{ppm}$ for chloroform- $d$. Routine ${ }^{13} \mathrm{C}$ NMR spectra were fully decoupled by broad-band decoupling.

Chiral HPLC analyses were performed on a Thermo Separation Products Spectraseries P100 amd UV100 or P200 and UV200 using Chiralcel ${ }^{\circledR}$ columns (AD, AS, $\mathrm{OB}-\mathrm{H}, \mathrm{OC}, \mathrm{OD}$, or OJ) with heptane / 2-propanol mixtures with ratio of the eluent, flow 
rate, and column indicated. Retention times $\left(\tau_{R}\right)$ are reported in minutes (min). Chiral GC was performed on a Hewlett-Packard 6890 capillary gas chromatograph using a $30 \mathrm{~m} \mathrm{x}$ $0.252 \mathrm{~mm}$ J\&W CyclosilB column. Optical rotations were determined using a JASCO DIP-1000 digital polarimeter in 50-mm cells and the sodium D line $(589 \mathrm{~nm})$ at the temperature, solvent, and concentration indicated.

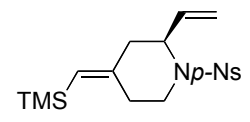

Compound 13. Following Condition $\mathrm{A}$ : $\left[\mathrm{CpRu}\left(\mathrm{CH}_{3} \mathrm{CN}\right)_{3}\right] \mathrm{PF}_{6}(4.3 \mathrm{mg}, 0.01 \mathrm{mmol})$ was added to a flame-dried test tube under argon. A solution of $14(65 \mathrm{mg}, 0.20 \mathrm{mmol})$ and 15 $(0.67 \mathrm{~g}, 0.35 \mathrm{mmol})$ in degassed acetone $(1.0 \mathrm{~mL})$ was added to the catalyst via cannula. The reaction was stirred at room temperature under argon for $3 \mathrm{~h}$ at which time it was diluted with $2.5 \mathrm{~mL}$ degassed DCM. DBU (32 $\mathrm{mg}, 0.21 \mathrm{mmol})$ was added followed by a solution of $(\mathrm{Pd}(\pi \text {-allyl }) \mathrm{Cl})_{2}(1.5 \mathrm{mg}, 0.004 \mathrm{mmol})$ and $(R, R)-\mathbf{L}-\mathbf{1}(8 \mathrm{mg}, 0.012 \mathrm{mmol})$ in $0.5 \mathrm{~mL}$ DCM. The resulting yellow solution was stirred for $1 \mathrm{~h}$ at room temperature at which point the mixture was concentrated in vacuo. The resulting oily residue was purified via flash chromatography (silica, $0-75 \%$ ether/petroleum ether, gradient) to yield $0.068 \mathrm{~g}(90 \%)$ of 13 as a white solid. $\mathrm{mp}=83-85^{\circ} \mathrm{C} . \mathrm{R}_{\mathrm{f}}=0.48$ in $50 \%$ ether/petroleum ether. $[\alpha]_{\mathrm{D}}-26.31\left(\mathrm{c}=1.51, \mathrm{CH}_{2} \mathrm{Cl}_{2}\right)$. Enantiomeric excess determined to be $89 \%$ by HPLC analysis. (Chiralcel OD column, 98:2 heptane:iPrOH, flow rate $=1.0 \mathrm{~mL} / \mathrm{min}$, 254nm, t $\mathrm{t}_{\mathrm{r}}$ : 20.93 (major), 24.73 (minor)). IR (neat): 3104, 1606, 1530, 1350, 1166, 855, $839 \mathrm{~cm}^{-1}$. ${ }^{1} \mathrm{H}$ NMR $\left(300 \mathrm{MHz}, \mathrm{CDCl}_{3}\right) \delta 8.32(\mathrm{~d}, \mathrm{~J}=9.0 \mathrm{~Hz}, 2 \mathrm{H}), 7.97(\mathrm{~d}, \mathrm{~J}=9.0 \mathrm{~Hz}, 2$ H), 5.59 (ddd, J = 17.4, 10.2, $6.9 \mathrm{~Hz}, 1 \mathrm{H}), 5.28$ (s, $1 \mathrm{H}), 5.09$ (m, $2 \mathrm{H}), 4.69$ (m, $1 \mathrm{H})$, $3.87(\mathrm{dd}, \mathrm{J}=12.6,4.5 \mathrm{~Hz}, 1 \mathrm{H}), 2.95(\mathrm{dt}, \mathrm{J}=3.3,12.6 \mathrm{~Hz}, 1 \mathrm{H}), 2.59$ (dd, J = 13.2, 5.7 $\mathrm{Hz}, 1 \mathrm{H}), 2.44(\mathrm{~d}, \mathrm{~J}=13.2 \mathrm{~Hz}, 1 \mathrm{H}), 2.20$ (m, $2 \mathrm{H}), 0.06(\mathrm{~s}, 9 \mathrm{H}) .{ }^{13} \mathrm{C}$ NMR $(75 \mathrm{MHz}$, $\left.\mathrm{CDCl}_{3}\right) \delta 149.80,148.35,146.20,133.55,128.46$ (2 C), 127.85, 124.19 (2 C), 118.51, 57.08, 43.76, 42.45, 32.85, 0.16 (3 C). Anal calcd for $\mathrm{C}_{17} \mathrm{H}_{24} \mathrm{~N}_{2} \mathrm{O}_{4} \mathrm{SSi}: \mathrm{C}, 53.66 \%$; $\mathrm{H}$, $6.36 \%$; N, 7.36\%. Found: C, 53.69\%; H, 6.46\%; N, 7.18\%.

\section{$\mathrm{TMS}_{\mathrm{NH} p-\mathrm{Ns}}$}

Compound 14. DEAD $(0.77 \mathrm{~g}, 4.4 \mathrm{mmol})$ was added dropwise to a cooled $\left(0{ }^{\circ} \mathrm{C}\right)$ solution of 4-trimethylsilanyl-but-3-yn-1-ol (0.44 g, $3.1 \mathrm{mmol}), \mathrm{PPh}_{3}(0.90 \mathrm{~g}, 3.4 \mathrm{mmol})$, and NHBocNos $(1.13 \mathrm{~g}, 3.7 \mathrm{mmol})$ in $10 \mathrm{~mL}$ THF. The reaction was stirred at room temperature for $5 \mathrm{~h}$ at which time it was concentrated in vacuo. The resulting oily residue was purified via flash chromatography (silica, ether/petroleum ether, gradient) to yield $1.2 \mathrm{~g}(90 \%)$ of bisprotected amine as a light yellow solid. The product $(1.40 \mathrm{~g}, 3.3$ mmol) was dissolved in $13 \mathrm{~mL}$ dichloromethane and cooled to $0{ }^{\circ} \mathrm{C}$. TFA $(2.1 \mathrm{~g}, 18$ mmol) was added dropwise and the reaction was stirred at room temperature for $10 \mathrm{~h}$. The resulting mixture was concentrated in vacuo and purified by flash chromatography (silica, ether/petroleum ether, gradient) to yield $0.74 \mathrm{~g} \mathrm{(70 \% )} \mathrm{of} 14$ as a white solid. mp $=114-115^{\circ} \mathrm{C} . \mathrm{R}_{\mathrm{f}}=0.45$ in $50 \%$ ether/petroleum ether. IR (film from $\mathrm{CDCl}_{3}$ ): 3300 , 2171, 1531, 1350, 1165, $844 \mathrm{~cm}^{-1} .{ }^{1} \mathrm{H}$ NMR $\left(300 \mathrm{MHz}, \mathrm{CDCl}_{3}\right) \delta 8.38(\mathrm{~d}, \mathrm{~J}=8.7 \mathrm{~Hz}, 2$ $\mathrm{H}), 8.07(\mathrm{~d}, \mathrm{~J}=8.7 \mathrm{~Hz}, 2 \mathrm{H}), 4.89(\mathrm{~m}, 1 \mathrm{H}), 3.17(\mathrm{q}, \mathrm{J}=6.3 \mathrm{~Hz}, 2 \mathrm{H}), 2.42(\mathrm{t}, \mathrm{J}=6.3 \mathrm{~Hz}, 2$ $\mathrm{H}), 0.14(\mathrm{~s}, 9 \mathrm{H}) .{ }^{13} \mathrm{C}$ NMR $\left(125 \mathrm{MHz}, \mathrm{CDCl}_{3}\right) \delta 150.10,145.95,128.25(2 \mathrm{C}), 124.46$ (2 
C), 101.69, 88.26, 41.73, 21.15, $-0.06(3 \mathrm{H})$. Anal calcd for $\mathrm{C}_{13} \mathrm{H}_{18} \mathrm{~N}_{2} \mathrm{O}_{4} \mathrm{SSi}$ : C, 47.83\%; H, 5.56\%; N, 8.58\%. Found: C, 47.67\%; H, 5.47\%; N, 8.56\%.

$\mathrm{TMS}=\mathrm{NHp-Ns}$

Compound 16. DEAD $(1.4 \mathrm{~g}, 7.9 \mathrm{mmol})$ was added dropwise to a cooled $\left(0{ }^{\circ} \mathrm{C}\right)$ solution of 3-trimethylsilanyl-prop-2-yn-1-ol (0.68 g, $5.3 \mathrm{mmol})$, NHBocNos (1.92 g, $6.35 \mathrm{mmol})$, and $\mathrm{PPh}_{3}(1.5 \mathrm{~g}, 5.8 \mathrm{mmol})$ in $19 \mathrm{~mL}$ THF. The reaction was stirred at room temperature for $4 \mathrm{~h}$ at which time it was concentrated in vacuo. The resulting oily residue was purified directly by flash chromatography to yield $1.85 \mathrm{~g}(84 \%)$ of bisprotected amine as a white solid. The solid $(0.83 \mathrm{~g}, 2.0 \mathrm{mmol})$ was dissolved in DCM $(8 \mathrm{~mL})$ and cooled to $0{ }^{\circ} \mathrm{C}$. TFA ( $1.6 \mathrm{~g}, 14.3 \mathrm{mmol})$ was added and the reaction was stirred $10 \mathrm{~h}$ while warming to room temperature. The mixture was directly concentrated in vacuo and purified by flash chromatography (silica, ether/petroleum ether, gradient) to yield $0.56 \mathrm{~g}(90 \%)$ of $\mathbf{1 6}$ as a white solid. $\mathrm{mp}=147-148{ }^{\circ} \mathrm{C} . \mathrm{R}_{\mathrm{f}}=0.78$ in $50 \%$ ether/petroleum ether. IR (film from $\left.\mathrm{Et}_{2} \mathrm{O}\right): 3318,1530,1340,1312,1172,997,847 \mathrm{~cm}^{-1} .{ }^{1} \mathrm{H}$ NMR $\left(300 \mathrm{MHz}, \mathrm{CDCl}_{3}\right) \delta 8.37$ $(\mathrm{d}, \mathrm{J}=9.0 \mathrm{~Hz}, 2 \mathrm{H}), 8.10(\mathrm{~d}, \mathrm{~J}=9.0 \mathrm{~Hz}, 2 \mathrm{H}), 4.82(\mathrm{~m}, 1 \mathrm{H}), 3.97(\mathrm{~d}, \mathrm{~J}=6.0 \mathrm{~Hz}, 2 \mathrm{H}),-$ $0.01(\mathrm{~s}, 9 \mathrm{H}) .{ }^{13} \mathrm{C}$ NMR $\left(75 \mathrm{MHz}, \mathrm{CDCl}_{3}\right) \delta 145.42,141.03,123.98(2 \mathrm{C}), 119.48(2 \mathrm{C})$, 93.76, 85.96, 29.12, -5.31 (3 C). Anal calcd for $\mathrm{C}_{12} \mathrm{H}_{16} \mathrm{~N}_{2} \mathrm{O}_{4} \mathrm{SSi}$ : C, 46.13\%; H, 5.16\%; N, $8.97 \%$. Found: C, $46.40 \%$; H, $5.25 \%$; N, 8.99\%.

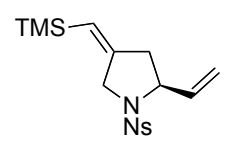

Compound 17. Following Condition $\mathrm{A}:\left[\mathrm{CpRu}\left(\mathrm{CH}_{3} \mathrm{CN}\right)_{3}\right] \mathrm{PF}_{6}(4.3 \mathrm{mg}, 0.01 \mathrm{mmol})$ was added to a flame-dried test tube under argon. A solution of $\mathbf{1 6}(62 \mathrm{mg}, 0.20 \mathrm{mmol})$ and 15 $(0.67 \mathrm{~g}, 0.35 \mathrm{mmol})$ in degassed acetone $(1.0 \mathrm{~mL})$ was added to the catalyst via cannula. The reaction was stirred at room temperature under argon for $3 \mathrm{~h}$ at which time it was diluted with $2.5 \mathrm{~mL}$ degassed DCM. DBU ( $32 \mathrm{mg}, 0.21 \mathrm{mmol})$ was added followed by a solution of $(\mathrm{Pd}(\pi-\text { allyl }) \mathrm{Cl})_{2}(1.5 \mathrm{mg}, 0.004 \mathrm{mmol})$ and $(R, R)-\mathbf{L}-\mathbf{1}(8 \mathrm{mg}, 0.012 \mathrm{mmol})$ in $0.5 \mathrm{~mL}$ DCM. The resulting yellow solution was stirred for $1 \mathrm{~h}$ at room temperature at which point the mixture was concentrated in vacuo. The resulting oily residue was purified via flash chromatography (silica, $0-75 \%$ ether/petroleum ether, gradient) to yield $66 \mathrm{mg}(90 \%)$ of 17 as a white solid. $\mathrm{mp}=90-91{ }^{\circ} \mathrm{C} .[\alpha]_{\mathrm{D}}+86.14\left(\mathrm{c}=0.94, \mathrm{CH}_{2} \mathrm{Cl}_{2}\right)$. The enantiomeric excess was determined to be $92 \%$ by chiral HPLC analysis. (Chiralcel OD column, 98:2 heptane: $\mathrm{PPOH}$, flow rate $=1.0 \mathrm{~mL} / \mathrm{min}, 254 \mathrm{~nm}, \mathrm{t}_{\mathrm{r}}: 20.65$ (major), 23.25 (minor)). IR (film from $\mathrm{CH}_{2} \mathrm{Cl}_{2}$ ): 2956, 1638, 1606, 1401, 1351, 1306, 1249, 1168, 1091, 1053, 926, 840, 736, $688 \mathrm{~cm}^{-1} .{ }^{1} \mathrm{H}$ NMR $\left(500 \mathrm{MHz}, \mathrm{CDCl}_{3}\right) \delta 8.39(\mathrm{~d}, \mathrm{~J}=9.0 \mathrm{~Hz}, 2 \mathrm{H})$, $8.03(\mathrm{~d}, \mathrm{~J}=9.5 \mathrm{~Hz}, 2 \mathrm{H}), 5.68(\mathrm{ddd}, \mathrm{J}=17.0,10.0,7.0 \mathrm{~Hz}, 1 \mathrm{H}), 5.50(\mathrm{~s}, 1 \mathrm{H}), 5.24(\mathrm{~d}, \mathrm{~J}$ $=15.0 \mathrm{~Hz}, 1 \mathrm{H}), 5.13(\mathrm{~d}, \mathrm{~J}=9.5 \mathrm{~Hz}, 1 \mathrm{H}), 4.30(\mathrm{~m}, 1 \mathrm{H}), 3.99(\mathrm{t}, \mathrm{J}=1.0 \mathrm{~Hz}, 2 \mathrm{H}), 2.68$ $(\mathrm{dd}, \mathrm{J}=18.0,8.0 \mathrm{~Hz}, 1 \mathrm{H}), 2.40(\mathrm{~d}, \mathrm{~J}=16.0 \mathrm{~Hz}, 1 \mathrm{H}), 0.10(\mathrm{~s}, 9 \mathrm{H}) .{ }^{13} \mathrm{C} \mathrm{NMR}(125 \mathrm{MHz}$, $\mathrm{CDCl}_{3}$ ) \& 150.02, 149.66, 144.14, 136.52, 128.63 (2 C), 124.22 (2 C), 123.67, 116.57, $61.57,50.98,42.72,-0.68(3 \mathrm{C})$. Anal calcd for $\mathrm{C}_{16} \mathrm{H}_{22} \mathrm{~N}_{2} \mathrm{O}_{4} \mathrm{SSi}: \mathrm{C}, 52.43 \%, \mathrm{H}, 6.05 \%$, N, 7.64\%. Found: C, $52.31 \%$; H, 6.24\%; N, 7.64\%. 
$\mathrm{TMS} \rightleftharpoons \mathrm{NH}(\mathrm{O}-\mathrm{Ns})$

Compound 18. DEAD $(1.0 \mathrm{~g}, 5.7 \mathrm{mmol})$ was added dropwise to a cooled $\left(0{ }^{\circ} \mathrm{C}\right)$ solution of 4-trimethylsilanyl-but-3-yn-1-ol (0.44 g, $3.1 \mathrm{mmol}), 2$-nitrobenzenesulfonyl tertbutylcarbamate $(1.12 \mathrm{~g}, 3.7 \mathrm{mmol})$ and $\mathrm{PPh}_{3}(0.9 \mathrm{~g}, 3.46 \mathrm{mmol})$ in THF $(10 \mathrm{~mL})$. The reaction was stirred at room temperature overnight at which time it was concentrated in vacuo. The resulting oily residue was purified directly by flash chromatography to yield an oily solid which was directly dissolved in dichloromethane $(11.5 \mathrm{~mL})$ and cooled to 0 ${ }^{\circ} \mathrm{C}$. TFA (1.66 g, $14.6 \mathrm{mmol}$ ) was added and the reaction was stirred $5 \mathrm{~h}$ while warming to room temperature. The mixture was directly concentrated in vacuo and purified by flash chromatography (silica, ether/petroleum ether, gradient) to yield $0.61 \mathrm{~g}(60 \%)$ of 18 as an off-white solid. The solid was recrystallized from hot ether/hexanes to yield a white crystalline solid that was analytically pure. $m p=73-74{ }^{\circ} \mathrm{C} . \mathrm{R}_{\mathrm{f}}=0.52$ in ether/pet ether. IR (film from $\mathrm{CDCl}_{3}$ ): 3345, 2960, 2177, 1542, 1415, 1347, 1250, 1169, $844 \mathrm{~cm}^{-1} .{ }^{1} \mathrm{H}$ NMR (300 MHz, $\left.\mathrm{CDCl}_{3}\right) \delta 8.14(\mathrm{~m}, 1 \mathrm{H}), 7.90(\mathrm{~m}, 1 \mathrm{H}), 7.76(\mathrm{~m}, 2 \mathrm{H}), 5.77(\mathrm{t}, \mathrm{J}=6.0$ $\mathrm{Hz}, 1 \mathrm{H}), 3.25$ (q, J = 6.3 Hz, $2 \mathrm{H}), 2.46(\mathrm{t}, \mathrm{J}=6.3 \mathrm{~Hz}, 2 \mathrm{H}), 0.12$ (s, $9 \mathrm{H}) .{ }^{13} \mathrm{C}$ NMR $(75$ $\left.\mathrm{MHz}, \mathrm{CDCl}_{3}\right) \delta 148.03,133.85,133.64,132.92,130.89,125.54,101.67,88.05,42.41$, 20.92, -0.16 (3 C). Anal calcd for $\mathrm{C}_{13} \mathrm{H}_{18} \mathrm{~N}_{2} \mathrm{O}_{4} \mathrm{SSi}$ : C, 47.83\%; H, 5.56\%; N, 8.58\%. Found: C, 48.07\%; H, 5.61\%; N, 8.73\%.

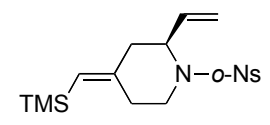

Compound 19. Following Condition $\mathrm{A}$ : $\left[\mathrm{CpRu}\left(\mathrm{CH}_{3} \mathrm{CN}\right)_{3}\right] \mathrm{PF}_{6}(4.3 \mathrm{mg}, 0.01 \mathrm{mmol})$ was added to a flame-dried test tube under argon. A solution of $18(65 \mathrm{mg}, 0.20 \mathrm{mmol})$ and 15 $(0.67 \mathrm{~g}, 0.35 \mathrm{mmol})$ in degassed acetone $(1.0 \mathrm{~mL})$ was added to the catalyst via cannula. The reaction was stirred at room temperature under argon for $3 \mathrm{~h}$ at which time it was diluted with $2.5 \mathrm{~mL}$ degassed DCM. DBU (32 $\mathrm{mg}, 0.21 \mathrm{mmol})$ was added followed by a solution of $(\mathrm{Pd}(\pi \text {-allyl }) \mathrm{Cl})_{2}(1.5 \mathrm{mg}, 0.004 \mathrm{mmol})$ and $(R, R)-\mathbf{L}-\mathbf{1}(8 \mathrm{mg}, 0.012 \mathrm{mmol})$ in $0.5 \mathrm{~mL}$ dichloromethane. The resulting yellow solution was stirred for $1 \mathrm{~h}$ at room temperature at which point the mixture was concentrated in vacuo. The resulting oily residue was purified via flash chromatography (silica, 0-75\% ether/petroleum ether, gradient) to yield $68 \mathrm{mg}(90 \%)$ of 19 as an oily solid. $\mathrm{R}_{\mathrm{f}}=0.48 \mathrm{in} 50 \%$ ether/pet ether. Enantiomeric excess was determined to be $88 \%$ ee by HPLC analysis. (Chiralcel OD column, 98:2 heptane $/ \mathrm{iPrOH}$, flow rate $=0.6 \mathrm{~mL} / \mathrm{min}, 254 \mathrm{~nm}, \mathrm{t}_{\mathrm{r}}: 28.17$ (minor), 30.21 (major)). $[\alpha]_{\mathrm{D}}-53.55\left(\mathrm{c}=1.03, \mathrm{CH}_{2} \mathrm{Cl}_{2}\right.$ ). IR (film from $\mathrm{CDCl}_{3}$ ): 2954, 1545, 1372, 1164 , $864,838 \mathrm{~cm}^{-1} .{ }^{1} \mathrm{H}$ NMR $\left(500 \mathrm{MHz}, \mathrm{CDCl}_{3}\right) \delta 8.10(\mathrm{~m}, 1 \mathrm{H}), 7.70(\mathrm{~m}, 3 \mathrm{H}), 5.75(\mathrm{ddd}, \mathrm{J}=$ 6.0, 10.5, 16.0 Hz, $1 \mathrm{H}), 5.32(\mathrm{~s}, 1 \mathrm{H}), 5.19$ (dd, J = 16.0, $1.5 \mathrm{~Hz}, 1 \mathrm{H}), 5.16(\mathrm{dd}, \mathrm{J}=10.5$, $1.5 \mathrm{~Hz}, 1 \mathrm{H}), 4.71(\mathrm{~m}, 1 \mathrm{H}), 3.83(\mathrm{ddd}, \mathrm{J}=13.0,3.5,1.5 \mathrm{~Hz}, 1 \mathrm{H}), 3.17$ (dt, J = 3.5, 13.0 $\mathrm{Hz}, 1 \mathrm{H}), 2.71(\mathrm{dd}, \mathrm{J}=13.0,6.0 \mathrm{~Hz}, 1 \mathrm{H}), 2.46(\mathrm{dd}, \mathrm{J}=13.0,1.5 \mathrm{~Hz}, 1 \mathrm{H}), 2.32$ (dd, J = 13.0, $2.0 \mathrm{~Hz}, 1 \mathrm{H}), 2.21(\mathrm{dt}, \mathrm{J}=5.5,13.0 \mathrm{~Hz}, 1 \mathrm{H}), 0.10(\mathrm{~s}, 9 \mathrm{H}) .{ }^{13} \mathrm{C} \mathrm{NMR}(125 \mathrm{MHz}$, $\left.\mathrm{CDCl}_{3}\right) \delta 149.11,147.74,134.50,133.90,133.42,131.72,130.94,127.39,124.25$, 118.28, 56.54, 42.95, 42.58, 33.15, 0.17 (3 C). Anal calcd for $\mathrm{C}_{17} \mathrm{H}_{24} \mathrm{~N}_{2} \mathrm{O}_{4} \mathrm{SSi}: \mathrm{C}$, $53.66 \%$; H, 6.36\%; N, 7.36\%. Found: C, 53.43\%; H, 6.22\%; N, 7.25\%. 
$\mathrm{TMS}=\sim_{\mathrm{NHp}-\mathrm{Ns}}$

Compound 20. DEAD $(1.1 \mathrm{~g}, 6.3 \mathrm{mmol})$ was added dropwise to a cooled $0{ }^{\circ} \mathrm{C}$ solution of containing 5-trimethylsilanyl-pent-4-yn-1-ol (0.49 g, $3.2 \mathrm{mmol}), \mathrm{NH}(\mathrm{Boc}) \mathrm{Nos}(1.14 \mathrm{~g}$, $3.8 \mathrm{mmol})$ and $\mathrm{PPh}_{3}(1.65 \mathrm{~g}, 6.3 \mathrm{mmol})$ in $\mathrm{THF}(10 \mathrm{~mL})$. The reaction was stirred at room temperature for 2 at which time it was concentrated in vacuo. The resulting oily residue was purified by flash chromatography (silica, ether/petroleum ether, gradient) to yield $1.23 \mathrm{~g}(88 \%)$ of bisprotected amine as a white solid. $\mathrm{R}_{\mathrm{f}}=0.55 \mathrm{in} 25 \%$ ether/pet ether. The solid was selectively deprotected in analogy to a literature procedure. ${ }^{6}$ The bisprotected amine (1.62 g, $3.9 \mathrm{mmol})$ was dissolved in DCM (34 mL). A solution of Bbromocatecholborane $(1.56 \mathrm{~g}, 7.8 \mathrm{mmol})$ in DCM $(16 \mathrm{~mL})$ was added via cannula. The reaction was stirred at room temperature for $40 \mathrm{~min}$ at which time it was quenched by the addition of water $(20 \mathrm{~mL})$. The biphasic mixture was stirred for $30 \mathrm{~min}$. The mixture was then diluted with dichloromethane. The organic layer was washed two times with $10 \%$ $\mathrm{NaOH}$ aqueous solution and once with brine. The organics were dried over $\mathrm{MgSO}_{4}$ and concentrate in vacuo to yield $1.07 \mathrm{~g}(80 \%)$ of $\mathbf{2 0}$ as a white solid. $\mathrm{mp}=93-95{ }^{\circ} \mathrm{C}$. For analytical purity, the compound was run through a column of silica in ether/pet ether $(+1 \% \mathrm{DCM})$ and then recrystallized from hot ether/hexanes to yield a white crystalline material (65\% from crude material). IR (film from $\mathrm{CDCl}_{3}$ ): 3299, 2959, 2174, 1532 , 1350, 1165, 1094, $845 \mathrm{~cm}^{-1} .{ }^{1} \mathrm{H}$ NMR $\left(300 \mathrm{MHz}, \mathrm{CDCl}_{3}\right) \delta 8.37(\mathrm{~d}, \mathrm{~J}=8.7 \mathrm{~Hz}, 2 \mathrm{H})$, $8.06(\mathrm{~d}, \mathrm{~J}=8.7 \mathrm{~Hz}, 2 \mathrm{H}), 5.03(\mathrm{~m}, 1 \mathrm{H}), 3.18(\mathrm{q}, \mathrm{J}=6.6 \mathrm{~Hz}, 2 \mathrm{H}), 2.27$ (p, J = 6.6 Hz, 2 $\mathrm{H}), 0.14(\mathrm{~s}, 9 \mathrm{H}) .{ }^{13} \mathrm{C} \mathrm{NMR}\left(125 \mathrm{MHz}, \mathrm{CDCl}_{3}\right) \delta 150.04,146.00,128.28(2 \mathrm{C}), 124.42(2$ C), 105.29, 86.82, 42.78, 27.88, 17.36, -0.04 (3 C). Anal calcd for $\mathrm{C}_{14} \mathrm{H}_{20} \mathrm{~N}_{2} \mathrm{O}_{4} \mathrm{SSi}$ : C, 4939\%; H, 5.92\%; N, 8.23\%. Found: C, 49.68\%; H, 6.08\%; N, 8.06\%.

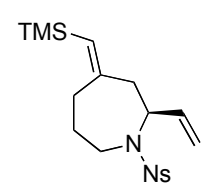

Compound 21. Following Condition $\mathrm{C}$ : $\left[\mathrm{CpRu}\left(\mathrm{CH}_{3} \mathrm{CN}\right)_{3}\right] \mathrm{PF}_{6}(5 \mathrm{mg}, 0.012 \mathrm{mmol})$ was added to a flame-dried test tube under argon. A solution of 20 (41 mg, $0.12 \mathrm{mmol})$ and 15 $(0.36 \mathrm{~g}, 0.19 \mathrm{mmol})$ in degassed acetone $(0.6 \mathrm{~mL})$ was added to the catalyst via cannula. The reaction was stirred at room temperature under argon for $3 \mathrm{~h}$ at which time it was diluted with $1.3 \mathrm{~mL}$ degassed DCM. DBU (18 $\mathrm{mg}, 0.12 \mathrm{mmol})$ was added followed by a solution of $(\mathrm{Pd}(\pi \text {-allyl }) \mathrm{Cl})_{2}(0.9 \mathrm{mg}, 0.0024 \mathrm{mmol})$ and $(R, R)-\mathbf{L}-\mathbf{1}(5 \mathrm{mg}, 0.007 \mathrm{mmol})$ in $0.5 \mathrm{~mL}$ DCM. The resulting yellow solution was stirred for $1 \mathrm{~h}$ at room temperature at which point the mixture was concentrated in vacuo. The resulting oily residue was purified via flash chromatography (silica, $0-75 \%$ ether/petroleum ether, gradient) to yield $17 \mathrm{mg}(37 \%)$ of $\mathbf{2 1}$ as an oily solid. The enantiomeric excess was determined to be $17 \%$ by chiral HPLC analysis. (Chiralcel AD column, 97:3 heptane: $\mathrm{PrOH}$, flow rate $=1.0$ $\mathrm{mL} / \mathrm{min}, 254 \mathrm{~nm}, \mathrm{t}_{\mathrm{r}}: 14.12$ (major), 15.60 (minor)). IR (film from $\mathrm{CDCl}_{3}$ ): 2953, 1531, 1350, 1161, 849, $740 \mathrm{~cm}^{-1} .{ }^{1} \mathrm{H}$ NMR $\left(300 \mathrm{MHz}, \mathrm{CDCl}_{3}\right) \delta 8.29(\mathrm{~d}, \mathrm{~J}=9.0 \mathrm{~Hz}, 2 \mathrm{H}), 7.97$ $(\mathrm{d}, \mathrm{J}=9.3 \mathrm{~Hz}, 2 \mathrm{H}), 5.56(\mathrm{ddd}, \mathrm{J}=6.3,10.2,17.1 \mathrm{~Hz}, 1 \mathrm{H}), 5.38(\mathrm{~s}, 1 \mathrm{H}), 5.03(\mathrm{dd}, \mathrm{J}=$ 17.1, 1.2 Hz, 1 H), 5.02 (dd, J = 10.2, $1.2 \mathrm{~Hz}, 1 \mathrm{H}), 4.55(\mathrm{~m}, 1 \mathrm{H}), 3.79$ (dt, J = 15.0, 3.6 $\mathrm{Hz}, 1 \mathrm{H}), 3.06(\mathrm{~m}, 1 \mathrm{H}), 2.63(\mathrm{dd}, \mathrm{J}=13.5,6.3 \mathrm{~Hz}, 1 \mathrm{H}), 2.50(\mathrm{dt}, \mathrm{J}=4.5,13.5 \mathrm{~Hz}, 1 \mathrm{H})$, $2.21(\mathrm{dd}, \mathrm{J}=13.5,9.6 \mathrm{~Hz}, 1 \mathrm{H}), 2.08(\mathrm{~m}, 1 \mathrm{H}), 1.73(\mathrm{~m}, 2 \mathrm{H}), 0.06(\mathrm{~s}, 9 \mathrm{H}) .{ }^{13} \mathrm{C} \mathrm{NMR}$ $\left(125 \mathrm{MHz}, \mathrm{CDCl}_{3}\right) \delta 152.86,149.65,147.11,135.98,129.36,128.48$ (2 C), 124.05 (2 C), 
116.44, 59.38, 46.34, 43.54, 35.50, 28.56, 0.09 (3 C). Anal calcd for $\mathrm{C}_{18} \mathrm{H}_{26} \mathrm{~N}_{2} \mathrm{O}_{4} \mathrm{SSi}: \mathrm{C}$, $54.79 \%$; H, 6.64\%; N, 7.10\%. Found: C, 54.97\%; H, 6.90\%, N, 7.33\%.

\section{Synthesis of Compound 22:}

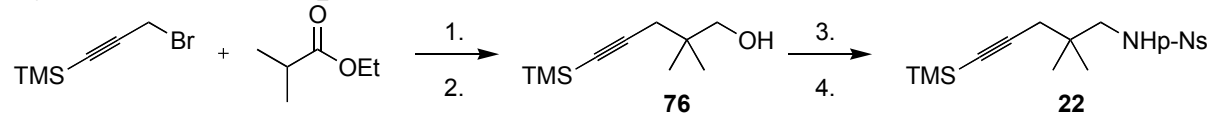

Compound 76. Step $1: n$-BuLi ( $6.9 \mathrm{~mL}$ of $1.6 \mathrm{M}$ in hexanes) was added dropwise to a cooled $\left(-78^{\circ} \mathrm{C}\right)$ solution of diisopropyl amine $(1.3 \mathrm{~g}, 12.5 \mathrm{mmol})$ in $30 \mathrm{~mL}$ THF. The solution was warmed slowly to $0{ }^{\circ} \mathrm{C}$ over $15 \mathrm{~min}$ at which time it was cooled to $-78{ }^{\circ} \mathrm{C}$. A solution of ethyl isobutyrate $(1.2 \mathrm{~g}, 10.0 \mathrm{mmol})$ in $15 \mathrm{~mL}$ THF was added dropwise to the anion. The mixture was stirred $1 \mathrm{~h}$ at $-78{ }^{\circ} \mathrm{C}$ at which time 3-bromo-1-trimethylsilyl1-propyne (1.98 g, $10.4 \mathrm{mmol}$ ) was added. The reaction turned bright orange in color. The reaction was warmed to room temperature and stirred overnight. The mixture was diluted with ether and $10 \%$ aqueous sodium bisulfate. The aqueous layer was extracted 3 times with ether. The combined organic layers were washed with brine, dried over magnesium sulfate, filtered, and concentrated in vacuo. The resulting oily residue was purified via flash chromatography (silica, ether/petroleum ether) to yield $1.66 \mathrm{~g}(73 \%)$ of ester as light yellow oil. $\mathrm{R}_{\mathrm{f}}=0.77$ in $10 \%$ ether/petroleum ether. Step2: The ester $(0.977 \mathrm{~g}, 5.3 \mathrm{mmol})$ was dissolved in $38 \mathrm{~mL}$ DCM and cooled to $-78{ }^{\circ} \mathrm{C}$. DIBAl-H $(17 \mathrm{~mL}$ of $1.0 \mathrm{M}$ in hexanes) was added and the reaction was stirred $30 \mathrm{~min}$ at $-78{ }^{\circ} \mathrm{C}$. The dry ice bath was removed and the reaction was warmed to room temperature and stirred an additional $2.5 \mathrm{~h}$. The resulting mixture was cooled to $0{ }^{\circ} \mathrm{C}$ at which time it was quenched with $21 \mathrm{~mL} \mathrm{MeOH}$ followed by a saturated aqueous solution of Rochelle's salt. The resulting solution was stirred vigorously until the emulsion broke. The resulting aqueous layer was extracted with DCM. The combined organic layers were dried over magnesium sulfate, filtered, and concentrated in vacuo. The resulting oily residue was purified by flash chromatography (silica, ether/petroleum ether, gradient) to yield $0.94 \mathrm{~g}(96 \%)$ of 76 as a colorless oil. $\mathrm{R}_{\mathrm{f}}=0.70$ in $25 \%$ ether/petroleum ether. ${ }^{1} \mathrm{H} \mathrm{NMR}\left(500 \mathrm{MHz}, \mathrm{CDCl}_{3}\right) \delta$ 3.44 (s, $2 \mathrm{H}), 2.20$ (s, $2 \mathrm{H}), 1.82(\mathrm{~s}, 1 \mathrm{H}), 0.99$ (s, $6 \mathrm{H}), 0.17(\mathrm{~s}, 9 \mathrm{H}) .{ }^{13} \mathrm{C} \mathrm{NMR}(125$ $\left.\mathrm{MHz}, \mathrm{CDCl}_{3}\right) \delta 105.02,86.77,71.11,35.59,29.84,23.77,0.08$ (3 C). This compound was fully characterized after conversion to $\mathbf{2 2}$.

Compound 22. Step 3: DEAD $(0.11 \mathrm{~g}, 0.64 \mathrm{mmol})$ was added to a cooled $\left(0{ }^{\circ} \mathrm{C}\right)$ solution of $76(0.07 \mathrm{~g}, 0.42 \mathrm{mmol}), \mathrm{NH}(\mathrm{BOC}) p-\mathrm{Ns}(0.16 \mathrm{~g}, 0.64 \mathrm{mmol})$, and triphenylphosphine $(0.17 \mathrm{~g}, 0.66 \mathrm{mmol})$ in $1.5 \mathrm{~mL}$ THF. The reaction was stirred at reflux overnight at which point it was concentrated in vacuo. The resulting oily residue was purified via flash chromatography (silica, ether/petroleum ether, gradient) to yield $0.15 \mathrm{~g}(79 \%)$ of bisprotected amine as a white solid. $\mathrm{R}_{\mathrm{f}}=0.54$ in $25 \%$ ether/petroleum ether. Step 4: A solution of B-bromocatecholborane $(1.43 \mathrm{~g}, 7.17 \mathrm{mmol})$ in $18 \mathrm{~mL}$ DCM was added to a solution of bisprotected amine $(1.67 \mathrm{~g}, 3.55 \mathrm{mmol})$ in $42 \mathrm{~mL}$ DCM. The reaction was stirred at room temperature for $2 \mathrm{~h}$ at which point $15 \mathrm{~mL} \mathrm{H}_{2} \mathrm{O}$ was added. The biphasic mixture was stirred an additional $20 \mathrm{~min}$ and then diluted with DCM. The organic layer was washed two times with $10 \% \mathrm{NaOH}$ (aq) solution and once with brine. The organic layer was then dried over magnesium sulfate and concentrated in vacuo. The resulting oily residue was purified by flash chromatography (silica, ether/petroleum ether, 
gradient) to yield $1.18 \mathrm{~g}(90 \%)$ of 22 as a white solid. $\mathrm{mp}=103-105^{\circ} \mathrm{C}$. IR (film from $\left.\mathrm{CDCl}_{3}\right): 3298,2962,2174,1534,1349,1166,843 \mathrm{~cm}^{-1} .{ }^{1} \mathrm{H} \mathrm{NMR}\left(500 \mathrm{MHz}, \mathrm{CDCl}_{3}\right) \delta$ $8.40(\mathrm{~d}, \mathrm{~J}=8.5 \mathrm{~Hz}, 2 \mathrm{H}), 8.07$ (d, J = 8.5 Hz, $2 \mathrm{H}), 5.06(\mathrm{t}, \mathrm{J}=6.5 \mathrm{~Hz}, 1 \mathrm{H}), 2.92$ (d, J = $6.5 \mathrm{~Hz}, 2 \mathrm{H}), 2.14(\mathrm{~s}, 2 \mathrm{H}), 0.99(\mathrm{~s}, 6 \mathrm{H}), 0.16(\mathrm{~s}, 9 \mathrm{H}) .{ }^{13} \mathrm{C} \mathrm{NMR}\left(125 \mathrm{MHz}, \mathrm{CDCl}_{3}\right) \delta$ 149.87, 145.97, 128.21 (2 C), 124.42 (2 C), 103.70, 88.19, 52.79, 34.19, 30.97, 24.96, 0.06 (3 C). Anal calcd for $\mathrm{C}_{16} \mathrm{H}_{24} \mathrm{~N}_{2} \mathrm{O}_{4} \mathrm{SSi}$ : C, 52.15\%; H, 6.56\%; N, 7.60\%. Found: $\mathrm{C}$, $52.22 \% ; \mathrm{H}, 6.34 \% ; \mathrm{N}, 7.48 \%$.

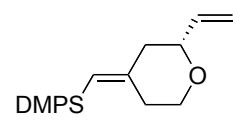

Compound 24. For Condition D: $\left[\mathrm{CpRu}\left(\mathrm{CH}_{3} \mathrm{CN}\right)_{3}\right] \mathrm{PF}_{6}(8 \mathrm{mg}, 0.02 \mathrm{mmol})$ was added to a flame-dried test tube under argon. A solution of $27(41 \mathrm{mg}, 0.20 \mathrm{mmol})$ and $15(0.23 \mathrm{~g}$, $1.2 \mathrm{mmol})$ in degassed acetone $(1.0 \mathrm{~mL})$ was added to the catalyst via cannula. The reaction was stirred at room temperature under argon for $3 \mathrm{~h}$ at which time it was directly concentrated in vacuo. The resulting oily residue was purged with argon and dissolved in $1.3 \mathrm{~mL}$ degassed DCM. NEt $3(0.22 \mathrm{mmol})$ was added followed by a solution of $\mathrm{Pd}_{2}(\mathrm{dba})_{3} \cdot \mathrm{CHCl}_{3}(0.004 \mathrm{mmol})$ and $(R, R)-\mathbf{L}-1(0.012 \mathrm{mmol})$ in $0.5 \mathrm{~mL}$ degassed DCM. The resulting red solution was stirred for $2 \mathrm{~h}$ at $0{ }^{\circ} \mathrm{C}$ at which point the mixture was concentrated in vacuo. The resulting oily residue was purified via flash chromatography (silica, $0-75 \%$ ether/petroleum ether, gradient) to yield $64 \mathrm{mg}(80 \%)$ of $\mathbf{2 4}$ as a colorless oil. $[\alpha]_{\mathrm{D}}-37.95\left(\mathrm{c}=1.00, \mathrm{CH}_{2} \mathrm{Cl}_{2}\right)$. The enantiomeric excess was determined to be $92 \%$ via HPLC analysis. (Chiralcel OD column, 100\% heptane, flow rate $=1.0 \mathrm{~mL} / \mathrm{min}, 254$ $\mathrm{nm}, \mathrm{t}_{\mathrm{r}}$ : 10.05 (major), 11.01 (minor)). IR (neat): 3069, 2956, 1621, 1428, 1374, 1138, 1113, 991, 868, $834 \mathrm{~cm}^{-1} .{ }^{1} \mathrm{H}$ NMR $\left(300 \mathrm{MHz}, \mathrm{CDCl}_{3}\right): \delta 7.46(\mathrm{~m}, 2 \mathrm{H}), 7.26(\mathrm{~m}, 3 \mathrm{H})$, 5.79 (ddd, J = 5.7, 10.5, 17.4 Hz, 1 H), 5.34 (s, 1 H), 5.18 (d, J = 17.4 Hz, $1 \mathrm{H}), 5.05$ (d, J $=10.5 \mathrm{~Hz}, 1 \mathrm{H}), 3.92(\mathrm{~m}, 1 \mathrm{H}), 3.75(\mathrm{~m}, 1 \mathrm{H}), 3.23(\mathrm{dt}, \mathrm{J}=3.3,10.8 \mathrm{~Hz}, 1 \mathrm{H}), 2.15(\mathrm{~m}, 4$ $\mathrm{H}), 0.28(\mathrm{~s}, 3 \mathrm{H}), 0.27(\mathrm{~s}, 3 \mathrm{H}) .{ }^{13} \mathrm{C} \mathrm{NMR}\left(75 \mathrm{MHz}, \mathrm{CDCl}_{3}\right): \delta 154.89,139.68,138.54$, 133.66 (2 C), 128.84, 127.78 (2 C), 121.08, 115.33, 79.34, 68.04, 45.66, 34.61, -0.67, 0.86. Anal calcd for $\mathrm{C}_{16} \mathrm{H}_{22} \mathrm{OSi}$ : C, 74.36\%; H, 8.58\%. Found: C, 74.23\%; H, 8.62\%.

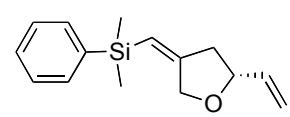

Compound 26. For Condition $\mathrm{D}$ : $\left[\mathrm{CpRu}\left(\mathrm{CH}_{3} \mathrm{CN}\right)_{3}\right] \mathrm{PF}_{6}(4 \mathrm{mg}, 0.02 \mathrm{mmol})$ was added to a flame-dried test tube under argon. A solution of $25(0.019 \mathrm{~g}, 0.10 \mathrm{mmol})$ and $15(0.115$ $\mathrm{g}, 0.6 \mathrm{mmol})$ in degassed acetone $(0.5 \mathrm{~mL})$ was added to the catalyst via cannula. The reaction was stirred at room temperature under argon for $3 \mathrm{~h}$ at which time it was directly concentrated in vacuo. The resulting oily residue was purged with argon and dissolved in $1.0 \mathrm{~mL}$ degassed $\mathrm{DCM} \mathrm{NEt}_{3}(16 \mathrm{mg}, 0.11 \mathrm{mmol})$ was added followed by a solution of $\mathrm{Pd}_{2}(\mathrm{dba})_{3} \cdot \mathrm{CHCl}_{3}(2.4 \mathrm{mg}, 0.0023 \mathrm{mmol})$ and $(R, R)-\mathbf{L}-1$ (5 mg, $\left.0.007 \mathrm{mmol}\right)$ in $0.3 \mathrm{~mL}$ degassed DCM. The resulting red solution was stirred for $2 \mathrm{~h}$ at $0{ }^{\circ} \mathrm{C}$ at which point the mixture was concentrated in vacuo. The resulting oily residue was purified via flash chromatography (silica, $0-75 \%$ ether/petroleum ether, gradient) to yield $21 \mathrm{mg}$ $(84 \%)$ of 26 as a colorless oil. $[\alpha]_{\mathrm{D}}+31.46\left(\mathrm{c}=1.32, \mathrm{CH}_{2} \mathrm{Cl}_{2}\right)$. The enantiomeric excess was determined to be $73 \%$ via HPLC analysis of a derivative (77). IR (neat): 2956, 1634, 
1428, 1248, 1117, 1053, 863, 730, $700 \mathrm{~cm}^{-1} .{ }^{1} \mathrm{H}$ NMR (500 MHz, $\left.\mathrm{CDCl}_{3}\right) \delta 7.54(\mathrm{~m}, 2$ H), $7.38(\mathrm{~m}, 3 \mathrm{H}), 5.89$ (ddd, J = 17.0, 10.5, 6.5 Hz, $1 \mathrm{H}), 5.64(\mathrm{dt}, \mathrm{J}=17.0,1.5 \mathrm{~Hz}, 1 \mathrm{H})$, $5.18(\mathrm{dt}, \mathrm{J}=10.5,1.5 \mathrm{~Hz}, 1 \mathrm{H}), 5.09(\mathrm{~m}, 1 \mathrm{H}), 4.36(\mathrm{~m}, 1 \mathrm{H}), 4.29(\mathrm{~d}, \mathrm{~J}=13.5 \mathrm{~Hz}, 1 \mathrm{H})$, $4.13(\mathrm{dt}, \mathrm{J}=13.5,1.0 \mathrm{~Hz}, 1 \mathrm{H}), 2.79(\mathrm{dd}, \mathrm{J}=16.0,6.5 \mathrm{~Hz}, 1 \mathrm{H}), 2.50$ (dd, J = 16.0, 8.5 $\mathrm{Hz}, 1 \mathrm{H}), 0.39$ (s, $3 \mathrm{H}), 0.37$ (s, $3 \mathrm{H}) .{ }^{13} \mathrm{C} \mathrm{NMR}\left(125 \mathrm{MHz}, \mathrm{CDCl}_{3}\right) \delta 158.36,138.59$, 137.76, 133.65 (2 C), 129.07, 127.87 (2 C), 116.67, 116.31, 79.43, 70.26, 42.64, -1.73, 1.75. Anal calcd for $\mathrm{C}_{15} \mathrm{H}_{20} \mathrm{OSi}$ : C, 73.71\%; H, 8.25\%. Found: C, 73.95\%; H, 8.46\%.<smiles>CCOCC[C@H]1CC(=CC=[W][Na])CO1</smiles>

Compound 77. Step 1: $9-\mathrm{BBN}(0.15 \mathrm{~mL}$ of $0.5 \mathrm{M}$ in THF, $0.075 \mathrm{mmol})$ was added to a room temperature solution of $26(0.019 \mathrm{~g}, 0.078 \mathrm{mmol})$ in $0.8 \mathrm{~mL}$ of THF. The resulting solution was stirred for $2 \mathrm{~h}$ at which time it was chilled to $0{ }^{\circ} \mathrm{C}$, and $0.24 \mathrm{~mL}$ of $1 \mathrm{M}$ aqueous $\mathrm{NaOH}$ and $0.24 \mathrm{~mL}$ of $30 \%$ wt. $\mathrm{H}_{2} \mathrm{O}_{2}$ were added simultaneously. The reaction was stirred overnight while slowly warming to room temperature. The solution was then diluted with methylene chloride, washed with $10 \% \mathrm{NaHSO}_{4}$ followed by brine. The organic layer was dried over magnesium sulfate, concentrated in vacuo and purified via flash chromatography (silica, ether/petroleum ether, gradient) to yield $0.0189 \mathrm{~g}(92 \%)$ of alcohol as a colorless oil. Step 2: Benzoyl chloride $(11.3 \mu \mathrm{L}, 0.08 \mathrm{mmol})$ was added to a cooled $\left(0{ }^{\circ} \mathrm{C}\right)$ solution of alcohol $(8.2 \mathrm{mg}, 0.031 \mathrm{mmol})$, dimethylamino pyridine $(3 \mathrm{mg}$, $0.024 \mathrm{mmol})$, and $\mathrm{NEt}_{3}(14 \mu \mathrm{L}, 0.14 \mathrm{mmol})$ in $0.2 \mathrm{~mL}$ DCM. The solution was stirred at room temperature for $2 \mathrm{~h}$ at which time it was diluted with DCM, washed with saturated ammonium chloride followed by brine. The organic layer was dried over magnesium sulfate, concentrated in vacuo, and purified by flash chromatography (silica, ether/petroleum ether, gradient) to yield $11 \mathrm{~g}(98 \%)$ of 77 as a colorless oil. $\mathrm{R}_{\mathrm{f}}=0.77$ in $50 \%$ ether/petroleum ether. Up to $79 \%$ ee as determined by HPLC analysis. (Chiralcel OD column, 99:1 heptane:iPrOH, flow rate $=1.0 \mathrm{~mL} / \mathrm{min}, 254 \mathrm{~nm}, \mathrm{t}_{\mathrm{r}}: 13.41$ (minor), 14.82 (major)). For ee $=30 \%,[\alpha]_{\mathrm{D}}+16.25\left(\mathrm{c}=0.24, \mathrm{CDCl}_{3}\right)$. IR (film from $\left.\mathrm{CDCl}_{3}\right)$ : 2957, 1721, 1633, 1274, 1176, 1069, 831, $712 \mathrm{~cm}^{-1} .{ }^{1} \mathrm{H}$ NMR $\left(300 \mathrm{MHz}, \mathrm{CDCl}_{3}\right) \delta 8.03$ $(\mathrm{d}, \mathrm{J}=8.1 \mathrm{~Hz}, 2 \mathrm{H}), 7.50(\mathrm{~m}, 3 \mathrm{H}), 7.44(\mathrm{~m}, 2 \mathrm{H}), 7.35(\mathrm{~m}, 3 \mathrm{H}), 5.65(\mathrm{~m}, 1 \mathrm{H}), 4.43$ (q, J $=6.3 \mathrm{~Hz}, 2 \mathrm{H}), 4.24(\mathrm{~d}, \mathrm{~J}=14.1 \mathrm{~Hz}, 1 \mathrm{H}), 3.90(\mathrm{~m}, 2 \mathrm{H}), 2.77(\mathrm{dd}, \mathrm{J}=16.5,6.0 \mathrm{~Hz}, 1 \mathrm{H})$, $2.41(\mathrm{dd}, \mathrm{J}=16.5,8.7 \mathrm{~Hz}, 1 \mathrm{H}), 2.20(\mathrm{p}, \mathrm{J}=6.3 \mathrm{~Hz}, 2 \mathrm{H}), 0.35(\mathrm{~s}, 6 \mathrm{H}) .{ }^{13} \mathrm{C} \mathrm{NMR}(75$ $\left.\mathrm{MHz} \mathrm{CDCl}_{3}\right) \delta 166.55,158.39,138.60,133.65$ (2 C), 132.90, 130.95, 129.55 (2 C), 129.08, 128.08 (2 C), 127.89 (2 C), 116.92, 75.77, 70.17, 62.13, 42.60, 34.03, -1.75 (2 C). Anal calcd for $\mathrm{C}_{22} \mathrm{H}_{26} \mathrm{O}_{3} \mathrm{Si}$ : C, 72.09\%; H, 7.15\%. Found: C, 71.99\%; H, 7.03\%.

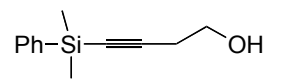

Compound 27. $n$-Butyllithium (26.25 $\mathrm{mL}$ of $1.6 \mathrm{M}$ in hexanes) was added dropwise to a cooled $\left(-78^{\circ} \mathrm{C}\right)$ solution of 3-buten-1-ol $(1.4 \mathrm{~g}, 20 \mathrm{mmol})$ in $67 \mathrm{~mL}$ THF. The reaction was stirred 20 minutes while warming to $0{ }^{\circ} \mathrm{C}$. The reaction was then cooled to $-78{ }^{\circ} \mathrm{C}$ at which time $\mathrm{Me}_{2} \mathrm{PhSiCl}(7.0 \mathrm{~g}, 41 \mathrm{mmol})$ was added. The reaction was stirred and warmed to room temperature over $4 \mathrm{~h}$. The mixture was quenched by addition of $5 \mathrm{~mL} \mathrm{MeOH}$ and acidified to $\mathrm{pH} 2$ with concentrated $\mathrm{HCl}$. The acidic mixture was stirred an additional 15 min at which time water was added. The aqueous layer was extracted three times with 
ether. The combined organic layers were washed with brine, dried over magnesium sulfate, and concentrated in vacuo. The resulting oily residue was purified via flash chromatography (silica, ether/petroleum ether, gradient) to yield $3.04 \mathrm{~g}(74 \%)$ of 27 as a colorless oil. $\mathrm{R}_{\mathrm{f}}=0.15$ in $20 \%$ ether/petroleum ether. IR (neat): $3356,3070,2176,1428$, 1250, 1115, 1031, 892, $838 \mathrm{~cm}^{-1}$. ${ }^{1} \mathrm{H}$ NMR (300 MHz, $\left.\mathrm{CDCl}_{3}\right) \delta 7.63(\mathrm{~m}, 2 \mathrm{H}), 7.37$ (m, $3 \mathrm{H}), 3.75(\mathrm{t}, \mathrm{J}=6.3 \mathrm{~Hz}, 2 \mathrm{H}), 2.56(\mathrm{t}, \mathrm{J}=6.6 \mathrm{~Hz}, 2 \mathrm{H}), 1.69(\mathrm{~s}, 1 \mathrm{H}), 0.41(\mathrm{~s}, 6 \mathrm{H}) .{ }^{13} \mathrm{C}$ NMR (125 MHz, $\left.\mathrm{CDCl}_{3}\right) \delta 137.10,133.59$ (2 C), 129.40, 127.88 (2 C), 105.19, 85.03, $60.89,24.37,-0.78$ (2 C). Anal calcd for $\mathrm{C}_{12} \mathrm{H}_{16} \mathrm{OSi}$ : C, 70.53\%; H, 7.89\%. Found: $\mathrm{C}$, $70.59 \% ; \mathrm{H}, 7.66 \%$.

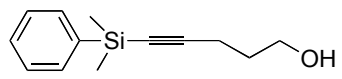

Compound 28. $n$-Butyllithium $(4.3 \mathrm{~mL}$ of $2.54 \mathrm{M}$ in hexanes) was added dropwise to a cooled $\left(-78^{\circ} \mathrm{C}\right)$ solution of 4-pentyn-1-ol $(0.42 \mathrm{~g}, 5.0 \mathrm{mmol})$ in $25 \mathrm{~mL}$ THF. The reaction was stirred for $20 \mathrm{~min}$ while warming to $0{ }^{\circ} \mathrm{C}$. The reaction was cooled to $-78{ }^{\circ} \mathrm{C}$ at which time $\mathrm{Me}_{2} \mathrm{PhSiCl}(1.9 \mathrm{~g}, 11.0 \mathrm{mmol})$ was added. The reaction was stirred and warmed to room temperature over $4 \mathrm{~h}$. The reaction was quenched by addition of $5 \mathrm{~mL}$ $\mathrm{MeOH}$ and acidified to $\mathrm{pH} 2$ via addition of conc. $\mathrm{HCl}$. The reaction was stirred an additional $15 \mathrm{~min}$ at which time it was poured into water. The aqueous layer was extracted three times with ether. The combined organic layers were washed with brine, dried over magnesium sulfate, and concentrated in vacuo. The resulting oily residue was purified via flash chromatography (silica, ether/petroleum ether, gradient) to yield $0.76 \mathrm{~g}$ (70 \%) of 28 as a colorless oil. IR (film from $\mathrm{CDCl}_{3}$ ): 3346, 2957, 2175, 1429, 1250, 1116, 837, $817 \mathrm{~cm}^{-1} .{ }^{1} \mathrm{H}$ NMR (400 MHz, $\left.\mathrm{CDCl}_{3}\right) \delta 7.60(\mathrm{~m}, 2 \mathrm{H}), 7.36(\mathrm{~m}, 3 \mathrm{H}), 3.75(\mathrm{t}$, $\mathrm{J}=6.4 \mathrm{~Hz}, 2 \mathrm{H}), 2.39(\mathrm{t}, \mathrm{J}=6.8 \mathrm{~Hz}, 2 \mathrm{H}), 1.79(\mathrm{p}, \mathrm{J}=6.4 \mathrm{~Hz}, 2 \mathrm{H}), 1.60(\mathrm{~s}, 1 \mathrm{H}), 0.38$ (s, $6 \mathrm{H}) .{ }^{13} \mathrm{C}$ NMR (100 MHz, $\left.\mathrm{CDCl}_{3}\right) \delta 137.36,133.59$ (2 C), 129.30, 127.83 (2 C), 108.48, 83.20, 61.79, 31.12, 16.59, -0.73 (2 C). Anal calcd for $\mathrm{C}_{13} \mathrm{H}_{18} \mathrm{OSi}$ : C, 71.50\%; $\mathrm{H}, 8.31 \%$. Found: C, 71.66\%; H, 8.06\%

\section{Synthesis of Compound 30.}

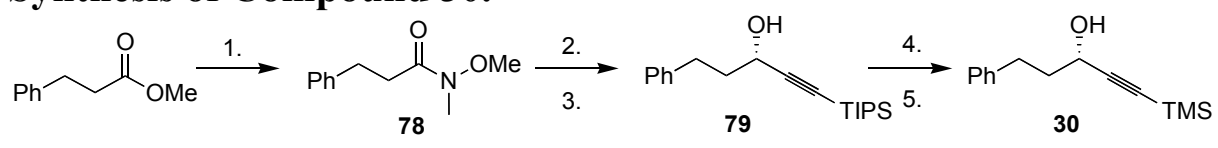

Compound 78. Step 1: The amide was prepared in analogy to a literature procedure. ${ }^{7}$

Trimethylaluminum $\left(10.5 \mathrm{~mL}\right.$ of $2.0 \mathrm{M}$ in toluene) was added to a cooled $\left(-5^{\circ} \mathrm{C}\right)$ slurry of MeNHOMe $(2.049 \mathrm{~g}, 21 \mathrm{mmol})$ in toluene $(25 \mathrm{ml})$. The solution was stirred at room temperature for $1 \mathrm{~h}$ at which time it was cooled to $0{ }^{\circ} \mathrm{C}$. A solution of ethyl 3-phenyl propionate $(1.78 \mathrm{~g}, 10 \mathrm{mmol})$ in toluene $(20 \mathrm{~mL})$ was then added dropiwse via cannula. The reaction was warmed to room temperature and stirred for $5 \mathrm{~h}$. The resulting solution was quenched carefully with dilute $\mathrm{HCl}$ (vigorous bubbling was observed). The aqueous later was extracted 3 times with ethyl acetate. The combined organic layers were washed with brine, dried over $\mathrm{MgSO}_{4}$, filtered, and concentrated in vacuo. The resulting oily residue was purified via flash chromatography (silica, 20-70\% ether/petroleum ether, gradient) to yield $1.59 \mathrm{~g}(82 \%)$ of $\mathbf{7 8}$ as a light yellow oil. $\mathrm{R}_{\mathrm{f}}=0.1 \mathrm{in} 50 \%$

ether/petroleum ether. IR (film from $\mathrm{CDCl}_{3}$ ): 2939, 1734, 1668, 1415, 1385, 1178, 1103 , 
$991 \mathrm{~cm}^{-1} .{ }^{1} \mathrm{H}$ NMR $\left(300 \mathrm{MHz}, \mathrm{CDCl}_{3}\right) \delta 7.25(\mathrm{~m}, 5 \mathrm{H}), 3.60(\mathrm{~s}, 3 \mathrm{H}), 3.18(\mathrm{~s}, 3 \mathrm{H}), 2.97$

$(\mathrm{t}, \mathrm{J}=7.8 \mathrm{~Hz}, 2 \mathrm{H}), 2.74(\mathrm{t}, \mathrm{J}=7.8 \mathrm{~Hz}, 2 \mathrm{H}) .{ }^{13} \mathrm{C} \mathrm{NMR}\left(75 \mathrm{MHz}, \mathrm{CDCl}_{3}\right) \delta 173.69$, 141.32, 128.40 (2 C), 126.06 (2 C), 61.16, 33.75, 32.15, 30.65 (2 C). Anal calcd for $\mathrm{C}_{11} \mathrm{H}_{15} \mathrm{NO}_{2}$ : C, 68.37\%; H, 7.82\%; N, 7.25\%. Found: C, 68.12\%; H, 7.62\%; N, 7.17\%.

Compound 79. Step $2: n$ Butyllithium $(8.25 \mathrm{~mL}$ of $2.5 \mathrm{M}$ in hexanes) was added to a cooled $\left(-78^{\circ} \mathrm{C}\right)$ solution of triisopropylsilyl acetylene $(4.0 \mathrm{~g}, 21.9 \mathrm{mmol})$ in THF (44 $\mathrm{mL})$. The solution was stirred $20 \mathrm{~min}$ while warming to $0{ }^{\circ} \mathrm{C}$ at which time it was cooled to $-78{ }^{\circ} \mathrm{C}$ and a solution of $78(2.5 \mathrm{~g}, 12.9 \mathrm{mmol})$ in $21 \mathrm{~mL}$ THF was added via cannula. The reaction was stirred for 2.5 hours while warming to $-10{ }^{\circ} \mathrm{C}$ at which time it was quenched with saturated aq. $\mathrm{NH}_{4} \mathrm{Cl}$. The aqueous layer was extracted 3 times with ether. The combined organic layers were washed with brine, dried over $\mathrm{MgSO}_{4}$, and concentrated in vacuo. The resulting oily reisdue was purified via flash chromatography (silica, ether/petroleum ether, gradient) to yield $4.0 \mathrm{~g}(97 \%)$ of silyl protected yne-one as a colorless oil. Step 3: The reduction was performed in analogy to a literature procedure. $^{8}(S, S)$-Noyori's catalyst $(0.17 \mathrm{~g}, 0.27 \mathrm{mmol})$ was added to a flask and the flask was flushed with argon. A solution of silyl protected yne-one $(4.26 \mathrm{~g}, 13.55 \mathrm{mmol})$ in 2propanol $(120 \mathrm{~mL})$ was added to the catalyst. The resulting solution turned from purple to red to light orange over $20 \mathrm{~min}$. The resulting solution was concentrated in vacuo and purified directly by flash chromatography (silica, ether/petroleum ether, gradient) to yield $4.28 \mathrm{~g}(100 \%)$ of 79 as a colorless oil. $[\alpha]_{\mathrm{D}}+27.17\left(\mathrm{c}=2.14, \mathrm{CH}_{2} \mathrm{Cl}_{2}\right)$. The enantiomeric excess was determined to be $99 \%$ via HPLC analysis of $\mathbf{3 0} . \mathrm{R}_{\mathrm{f}}=0.76$ in $50 \%$ ether/petroleum ether. IR (film from $\mathrm{CDCl}_{3}$ ): 3355, 2943, 2866, 2169, 1463, 1154, 1046, 833, $678 \mathrm{~cm}^{-1} .{ }^{1} \mathrm{H}$ NMR (500 MHz, $\left.\mathrm{CDCl}_{3}\right): \delta 7.33(\mathrm{~m}, 2 \mathrm{H}), 7.23(\mathrm{~m}, 3 \mathrm{H}), 4.43(\mathrm{t}, \mathrm{J}=$ $7.5 \mathrm{~Hz}, 1 \mathrm{H}), 2.85$ (t, J = 8.0 Hz, $2 \mathrm{H}), 2.05(\mathrm{~m}, 2 \mathrm{H}), 1.81($ broad s, $1 \mathrm{H}), 1.23(\mathrm{~m}, 21 \mathrm{H})$. ${ }^{13} \mathrm{C} \mathrm{NMR}\left(125 \mathrm{MHz}, \mathrm{CDCl}_{3}\right): \delta 141.40,128.50$ (3 C), 128.44, 125.96, 108.40, 86.04, 62.33, 39.58, 31.46, 18.59 (6 C), 11.11 (3 C). Anal calcd for $\mathrm{C}_{20} \mathrm{H}_{32} \mathrm{OSi}$ : C, $75.88 \%$; $\mathrm{H}$, $10.19 \%$. Found: C, $75.96 \%$; H, 9.97\%.

Compound 30. Step 4: Tetrabutylammonium flouride ( $25 \mathrm{~mL}$ of $1.0 \mathrm{M}$ solution in THF) was added to a solution of $79(3.99 \mathrm{~g}, 12.6 \mathrm{mmol})$ in wet THF $(120 \mathrm{~mL})$. The reaction was stirred for $45 \mathrm{~min}$ at room temperature at which time it was quenched with saturated aq. $\mathrm{NH}_{4} \mathrm{Cl}$. The aqueous layer was extract with ether 3 times. The combined organic layers were washed with brine, dried over $\mathrm{MgSO}_{4}$, filtered, and concentrated in vacuo. The resulting oily residue was purified via flash chromatography (silica, ether/petroleum ether, gradient) to yield $1.96 \mathrm{~g}(89.6 \%)$ of desilylated product as a colorless oil. Step 5: The desilylated compound $(10.4 \mathrm{mmol})$ was dissolved in THF $(56 \mathrm{~mL})$ and cooled to -78 ${ }^{\circ} \mathrm{C}$. $n$-BuLi (12.5 mL of $2.5 \mathrm{M}$ in hexanes) was added dropwise. The resulting solution was warmed to $0{ }^{\circ} \mathrm{C}$ over $25 \mathrm{~min}$ at which time it was cooled to $-78{ }^{\circ} \mathrm{C}$ and $\mathrm{TMSCl}(3.27$ $\mathrm{g}, 30.16 \mathrm{mmol}$ ) was added. The reaction was stirred $4 \mathrm{~h}$ while warming to room temperature at which time it was quenched via the addition of a solution of citric acic $(2.27 \mathrm{~g})$ in $\mathrm{MeOH}(24 \mathrm{~mL})$. The resulting solution was vigorously stirred at room temperature for $1 \mathrm{~h}$. The solution was then poured into a mixture of brine and ether. The aqueous layer was extracted 3 times with ether. The combined organic layers were dried over $\mathrm{MgSO}_{4}$, filtered, and concentrated in vacuo. The resulting oily residue was purified via flash chromatography (ether/petroleum ether) to yield $2.41 \mathrm{~g}(99 \%)$ of $\mathbf{3 0}$ as a 
colorless oil. The enantiomeric excess was determined to be $99 \%$ via HPLC analysis. (Chiralcel OD column, 90:10 heptane/iPrOH, flow rate $=1.0 \mathrm{~mL} / \mathrm{min}, 254 \mathrm{~nm}, \mathrm{t}_{\mathrm{r}}: 7.87$ (minor), 5.51 (major)). $[\alpha]_{\mathrm{D}}+32.91\left(\mathrm{c}=2.37, \mathrm{CH}_{2} \mathrm{Cl}_{2}\right) . \mathrm{R}_{\mathrm{f}}=0.64$ in $30 \%$

ether/petroleum ether. IR (film from $\mathrm{CDCl}_{3}$ ): 3356, 2958, 2172, 1251, 1047, $844 \mathrm{~cm}^{-1} \cdot{ }^{1} \mathrm{H}$ NMR (500 MHz, CDCl $)_{3}$ : $\delta 7.33(\mathrm{~m}, 2 \mathrm{H}), 7.24(\mathrm{~m}, 3 \mathrm{H}), 4.40(\mathrm{t}, \mathrm{J}=6.5 \mathrm{~Hz}, 1 \mathrm{H}), 2.83$ $(\mathrm{t}, \mathrm{J}=8.0 \mathrm{~Hz}, 2 \mathrm{H}), 2.04(\mathrm{~m}, 2 \mathrm{H}), 0.23(\mathrm{~s}, 9 \mathrm{H})$. Hydroxyl proton was not observed. ${ }^{13} \mathrm{C}$ NMR $\left(125 \mathrm{MHz}, \mathrm{CDCl}_{3}\right): \delta 141.25,128.47$ (3 C), 128.39, 125.95, 106.45, 89.83, 62.08, $39.14,31.36,-0.16$ (3 C). Anal calcd for $\mathrm{C}_{14} \mathrm{H}_{20} \mathrm{OSi}$ : C, 72.36\%; H, 8.67\%. Found: $\mathrm{C}$, $72.13 \% ; \mathrm{H}, 8.48 \%$.

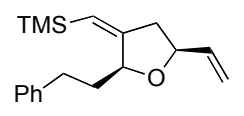

Compound 31. For Condition $\mathrm{D}$ : $\left[\mathrm{CpRu}\left(\mathrm{CH}_{3} \mathrm{CN}\right)_{3}\right] \mathrm{PF}_{6}(4 \mathrm{mg}, 0.01 \mathrm{mmol})$ was added to a flame-dried test tube under argon. A solution of $\mathbf{3 0}(23 \mathrm{mg}, 0.10 \mathrm{mmol})$ and $\mathbf{1 5}(0.115$ $\mathrm{g}, 0.6 \mathrm{mmol})$ in degassed acetone $(0.5 \mathrm{~mL})$ was added to the catalyst via cannula. The reaction was stirred at room temperature under argon for $3 \mathrm{~h}$ at which time it was directly concentrated in vacuo. The resulting oily residue was purged with argon and dissolved in $1.0 \mathrm{~mL}$ degassed DCM. $\mathrm{NEt}_{3}(16 \mathrm{mg}, 0.11 \mathrm{mmol})$ was added followed by a solution of $\mathrm{Pd}_{2}(\mathrm{dba})_{3} \cdot \mathrm{CHCl}_{3}(2.4 \mathrm{mg}, 0.0023 \mathrm{mmol})$ and $(S, S)-\mathbf{L}-1$ (5 mg, $\left.0.007 \mathrm{mmol}\right)$ in $0.3 \mathrm{~mL}$ degassed DCM. The resulting red solution was stirred for $2 \mathrm{~h}$ at $0{ }^{\circ} \mathrm{C}$ at which point the mixture was concentrated in vacuo. The resulting oily residue was purified via flash chromatography (silica, $0-75 \%$ ether/petroleum ether, gradient) to yield $23 \mathrm{mg}$ $(80 \%)$ of 31 as a colorless oil. $R_{f}=0.87$ in $30 \%$ ether/petroleum ether. The

diastereomeric ratio was determined to be 10:1 cis:trans by ${ }^{1} \mathrm{H}$ NMR. $[\alpha]_{\mathrm{D}}=-126.00(\mathrm{c}=$ $0.05, \mathrm{CH}_{2} \mathrm{Cl}_{2}$ ). A $4.2 \%$ nOe between $\mathrm{H}_{2}$ and $\mathrm{H}_{5}$ in $\mathrm{CDCl}_{3}$ was present for the isolated major isomer. IR (film from $\mathrm{CDCl}_{3}$ ): 2954, 1737, 1636, 1429, 1249, 1044, 925, $839 \mathrm{~cm}^{-1}$. ${ }^{1} \mathrm{H}$ NMR (500 MHz, $\left.\mathrm{CDCl}_{3}\right) \delta 7.29(\mathrm{~m}, 2 \mathrm{H}), 7.22(\mathrm{~m}, 3 \mathrm{H}), 5.96$ (ddd, J = 7.0, 10.5, 10.0 $\mathrm{Hz}, 1 \mathrm{H}), 5.51(\mathrm{~s}, 1 \mathrm{H}), 5.37$ (d, J = 17.0 Hz, $1 \mathrm{H}), 5.18(\mathrm{~d}, \mathrm{~J}=10.5 \mathrm{~Hz}, 1 \mathrm{H}), 4.54$ (d, J = $7.5 \mathrm{~Hz}, 1 \mathrm{H}), 4.36(\mathrm{~m}, 1 \mathrm{H}), 2.78(\mathrm{~m}, 2 \mathrm{H}), 2.58(\mathrm{~d}, \mathrm{~J}=8.0 \mathrm{~Hz}, 2 \mathrm{H}), 1.95(\mathrm{~m}, 1 \mathrm{H}), 1.86$ $(\mathrm{m}, 1 \mathrm{H}), 0.09(\mathrm{~s}, 9 \mathrm{H}) .{ }^{13} \mathrm{C} \mathrm{NMR}\left(125 \mathrm{MHz}, \mathrm{CDCl}_{3}\right) \delta 159.93,142.19,139.75,128.53(2$ C), 128.33 (2 C), 125.71, 119.73, 116.32, 79.24, 79.17, 44.01, 39.36, 31.51, -0.10 (3 C). Anal calcd for $\mathrm{C}_{18} \mathrm{H}_{26} \mathrm{OSi}$ : C, 75.48\%; H, 9.15\%. Found: C, 75.45\%; H, 8.97\%.

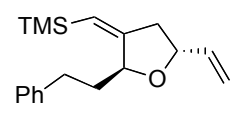

Compound 32. For Condition $\mathrm{D}$ : $\left[\mathrm{CpRu}\left(\mathrm{CH}_{3} \mathrm{CN}\right)_{3}\right] \mathrm{PF}_{6}(4 \mathrm{mg}, 0.01 \mathrm{mmol})$ was added to a flame-dried test tube under argon. A solution of $\mathbf{3 0}(23 \mathrm{mg}, 0.10 \mathrm{mmol})$ and $15(0.115$ $\mathrm{g}, 0.6 \mathrm{mmol})$ in degassed acetone $(0.5 \mathrm{~mL})$ was added to the catalyst via cannula. The reaction was stirred at room temperature under argon for $3 \mathrm{~h}$ at which time it was directly concentrated in vacuo. The resulting oily residue was purged with argon and dissolved in $1.0 \mathrm{~mL}$ degassed DCM. NEt $3(16 \mathrm{mg}, 0.11 \mathrm{mmol})$ was added followed by a solution of $\mathrm{Pd}_{2}(\mathrm{dba})_{3} \cdot \mathrm{CHCl}_{3}(2.4 \mathrm{mg}, 0.0023 \mathrm{mmol})$ and $(R, R)-\mathbf{L}-\mathbf{1}(5 \mathrm{mg}, 0.007 \mathrm{mmol})$ in $0.3 \mathrm{~mL}$ degassed DCM. The resulting red solution was stirred for $2 \mathrm{~h}$ at $0{ }^{\circ} \mathrm{C}$ at which point the mixture was concentrated in vacuo. The resulting oily residue was purified via 
flash chromatography (silica, $0-75 \%$ ether/petroleum ether, gradient) to yield $30 \mathrm{mg}$ $(87 \%)$ of 32 as a colorless oil. $R_{f}=0.87$ in $30 \%$ ether/petroleum ether. The

diastereomeric ratio was determined to be 3.5:1 trans: cis by ${ }^{1} \mathrm{H}$ NMR. Characterized as a mixture in which the peaks for the major diastereomer were identified: IR (film from $\left.\mathrm{CDCl}_{3}\right): 2953,1635,1430,1248,1044,988,747 \mathrm{~cm}^{-1} .{ }^{1} \mathrm{H} \mathrm{NMR}\left(500 \mathrm{MHz}, \mathrm{CDCl}_{3}\right): \delta$ $7.28(\mathrm{~m}, 2 \mathrm{H}), 7.24(\mathrm{~m}, 3 \mathrm{H}), 5.90(\mathrm{ddd}, \mathrm{J}=6.5,10.5,17.0 \mathrm{~Hz}, 1 \mathrm{H}), 5.47$ (s, $1 \mathrm{H}), 5.30$ $(\mathrm{d}, \mathrm{J}=17.0 \mathrm{~Hz}, 1 \mathrm{H}), 5.17(\mathrm{~d}, \mathrm{~J}=10.5 \mathrm{~Hz}, 1 \mathrm{H}), 4.57(\mathrm{~m}, 2 \mathrm{H}), 2.91(\mathrm{~m}, 2 \mathrm{H}), 1.79(\mathrm{~m}, 1$ $\mathrm{H}), 2.40(\mathrm{ddd}, \mathrm{J}=16.0,6.0,2.0 \mathrm{~Hz}, 1 \mathrm{H}), 1.90(\mathrm{~m}, 1 \mathrm{H}), 1.80(\mathrm{~m}, 1 \mathrm{H}), 0.07(\mathrm{~s}, 9 \mathrm{H}) .{ }^{13} \mathrm{C}$ NMR (125 MHz, $\left.\mathrm{CDCl}_{3}\right): \delta 159.40,142.05,138.63,128.56$ (2 C), 128.35 (2 C), 125.76, 119.70, 115.63, 79.05 (2 C), 42.22, 37.84, 32.19, -0.13 (3 C). Anal calcd for $\mathrm{C}_{18} \mathrm{H}_{26} \mathrm{OSi}$ : C, 75.48\%; H, 9.15\%. Found: C, 75.62\%; H, 9.25\%.

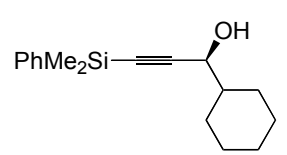

\section{Compound 33}

$n$-BuLi (11.0 mL of 1.6 $\mathrm{M}$ in hexanes) was added dropwise to a cooled $\left(-78{ }^{\circ} \mathrm{C}\right)$ solution of diphenylmethylsilyl acetylene $(2.9 \mathrm{~g}, 18.1 \mathrm{mmol})$ in THF $(90 \mathrm{~mL})$. The resulting solution was stirred at $0{ }^{\circ} \mathrm{C}$ for 30 min at which time it was cooled to $-78{ }^{\circ} \mathrm{C}$ and cyclohexanal $(1.85 \mathrm{~g}, 16.5 \mathrm{mmol})$ was added. The reaction was stirred at $-78{ }^{\circ} \mathrm{C}$ for $2 \mathrm{~h}$ at which time it was quenched with saturated aq. $\mathrm{NH}_{4} \mathrm{Cl}$. The aqueous layer was extracted 3 times with ether. The combined organic layers were dried over $\mathrm{MgSO}_{4}$, filtered, concentrated in vacuo, and purified via flash chromatography (silica, ether/petroleum ether, gradient) to yield $4.02 \mathrm{~g}(89 \%)$ of racemic alcohol as a colorless oil. This alcohol ( $3.71 \mathrm{~g}, 13.6 \mathrm{mmol})$ was dissolved in methylene chloride $(70 \mathrm{~mL}) .4 \AA$ Molecular seives were added followed by PCC (10.24 g, $27.23 \mathrm{mmol})$. The solution was stirred at room temperature overnight at which time the chromium salts were removed by filtratation through a plug of celite with methylene chloride. The filtrate was concentrated in vacuo and purified via flash chromatography (silica, ether/petroleum ether) to yield $3.42 \mathrm{~g}$ $(92 \%)$ of ketone as a colorless oil. The ketone $(0.73 \mathrm{~g}, 2.7 \mathrm{mmol})$ was dissolved in $20 \mathrm{~mL}$ iPrOH. $(S, S)$-Noyori's catalyst $(82 \mathrm{mg}, 0.13 \mathrm{mmol}$ ) was added to the solution and the reaction was stirred at room temperature for $3 \mathrm{~h}$. The reaction was concentrated in vacuo and purified directly via flash chromatography (silica, ether/petroleum ether) to yield $0.70 \mathrm{~g}(96 \%)$ of 33 as a colorless oil. $\mathrm{R}_{\mathrm{f}}=0.71$ in $30 \%$ ether/petroleum ether. The enantiomeric excess was determined to be $99 \%$ via HPLC analysis. (Chiralcel OD column, 98:2 heptane:iPrOH, flow rate $=1.0 \mathrm{~mL} / \mathrm{min}, 254 \mathrm{~nm}, \mathrm{t}_{\mathrm{r}}: 10.52$ (major), 15.77 (minor)). $[\alpha]_{\mathrm{D}}+3.74\left(\mathrm{c}=1.28, \mathrm{CH}_{2} \mathrm{Cl}_{2}\right.$ ). IR (film from $\left.\mathrm{CH}_{2} \mathrm{Cl}_{2}\right)$ : 3364, 2927, 2854, 2171 , 1451, 1429, 1250, 1116, 1084, $818 \mathrm{~cm}^{-1} .{ }^{1} \mathrm{H} \mathrm{NMR}\left(300 \mathrm{MHz}, \mathrm{CDCl}_{3}\right) \delta 7.50$ (m, $\left.2 \mathrm{H}\right)$, $7.26(\mathrm{~m}, 3 \mathrm{H}), 4.07$ (t, J = 5.4 Hz, $1 \mathrm{H}), 1.76-1.54(\mathrm{~m}, 6 \mathrm{H}), 1.16-0.96(\mathrm{~m}, 6 \mathrm{H}), 0.30$ (s, 6 H). ${ }^{13} \mathrm{C} \mathrm{NMR}\left(75 \mathrm{MHz}, \mathrm{CDCl}_{3}\right) \delta 136.85,133.66$ (2 C), 129.44, 127.87 (2 C), 107.63, $88.20,67.70,44.01,28.52,28.05,26.37,25.84,25.87,-0.86(2 \mathrm{C})$. Anal calcd for $\mathrm{C}_{17} \mathrm{H}_{24} \mathrm{OSi}$ : C, 74.94\%; H, 8.88\%. Found: C, 74.69\%; H, 8.63\%. 


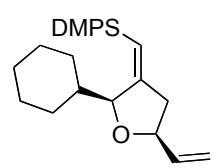

Compound 34. For Condition $\mathrm{D}$ : $\left[\mathrm{CpRu}\left(\mathrm{CH}_{3} \mathrm{CN}\right)_{3}\right] \mathrm{PF}_{6}(8.7 \mathrm{mg}, 0.02 \mathrm{mmol})$ was added to a flame-dried test tube under argon. A solution of $\mathbf{3 3}(56 \mathrm{mg}, 0.2 \mathrm{mmol})$ and $15(0.22$ $\mathrm{g}, 1.1 \mathrm{mmol})$ in degassed acetone $(1.0 \mathrm{~mL})$ was added to the catalyst via cannula. The reaction was stirred at room temperature under argon for $6 \mathrm{~h}$ at which time it was directly concentrated in vacuo. The resulting oily residue was purged with argon and dissolved in $2.0 \mathrm{~mL}$ degassed $\mathrm{DCM}$. $\mathrm{NEt}_{3}(0.031 \mathrm{~mL}, 0.22 \mathrm{~mol})$ was added followed by a solution of $\mathrm{Pd}_{2}(\mathrm{dba})_{3} \cdot \mathrm{CHCl}_{3}(4.1 \mathrm{mg}, 0.004 \mathrm{mmol})$ and $(S, S)-\mathbf{L}-1$ (8.3 $\left.\mathrm{mg}, 0.0119 \mathrm{mmol}\right)$ in $0.5 \mathrm{~mL}$ degassed DCM. The resulting red solution was stirred for $2 \mathrm{~h}$ at $0{ }^{\circ} \mathrm{C}$ at which point the mixture was concentrated in vacuo. The resulting oily residue was purified via flash chromatography (silica, $0-75 \%$ ether/petroleum ether, gradient) to yield $38 \mathrm{mg}$ $(57 \%, 81 \%$ brsm) of $\mathbf{3 4}$ as a colorless oil. The diastereomeric ratio was determined to be 23:1 cis:trans as determined by ${ }^{1} \mathrm{H}$ NMR (500 MHz). The cis isomer showed a $3.6 \% \mathrm{nOe}$ between $\mathrm{H}_{\mathrm{A}}$ and $\mathrm{H}_{\mathrm{B}}$. IR (film from $\mathrm{CDCl}_{3}$ ): 2927, 1630, 1428, 1248, 1113, 876, 730, 700 $\mathrm{cm}^{-1} .{ }^{1} \mathrm{H} \mathrm{NMR}\left(500 \mathrm{MHz}, \mathrm{CDCl}_{3}\right) \delta 7.53(\mathrm{~m}, 2 \mathrm{H}), 7.36(\mathrm{~m}, 3 \mathrm{H}), 5.87$ (ddd, J = 6.5, 10.5, 17.0 Hz, $1 \mathrm{H}), 5.63$ (t, J = 2.5 Hz, $1 \mathrm{H}), 5.30$ (d, J = 17.0 Hz, $1 \mathrm{H}), 5.14(\mathrm{~d}, \mathrm{~J}=10.5$ $\mathrm{Hz}, 1 \mathrm{H}), 4.28$ (p, J = 6.0 Hz, $1 \mathrm{H}), 4.11$ (apparent s, $1 \mathrm{H}), 2.55$ (dd, J = 5.0, $14.5 \mathrm{~Hz}, 1$ H), 2.39 (m, $1 \mathrm{H}), 1.65-1.53(\mathrm{~m}, 3 \mathrm{H}), 1.39-1.22(\mathrm{~m}, 4 \mathrm{H}), 1.17-1.00$ (m, $3 \mathrm{H}), 0.91-0.85$ $(\mathrm{m}, 1 \mathrm{H}), 0.38(\mathrm{~s}, 3 \mathrm{H}), 0.37$ (s, $3 \mathrm{H}) .{ }^{13} \mathrm{C} \mathrm{NMR}\left(125 \mathrm{MHz}, \mathrm{CDCl}_{3}\right) \delta 162.24,138.94$, 138.08, 133.73 (2 C), 128.97, 127.80 (2 C), 116.94, 116.35, 84.06, 78.82, 45.28, 43.36, 30.24, 26.74, 26.15, 26.08, 25.15, -1.21, -1.43. HRMS ( $\left.{ }^{+}-\mathrm{H}\right) \mathrm{C}_{21} \mathrm{H}_{29} \mathrm{OSi}$. Calcd: 325.1988. Found 325.1985.

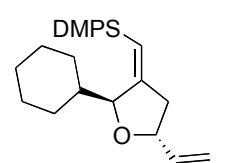

Compound 35. For Condition $\mathrm{D}$ : $\left[\mathrm{CpRu}\left(\mathrm{CH}_{3} \mathrm{CN}\right)_{3}\right] \mathrm{PF}_{6}(8.7 \mathrm{mg}, 0.02 \mathrm{mmol})$ was added to a flame-dried test tube under argon. A solution of $33(56 \mathrm{mg}, 0.2 \mathrm{mmol})$ and $15(0.22 \mathrm{~g}$, $1.1 \mathrm{mmol})$ in degassed acetone $(1.0 \mathrm{~mL})$ was added to the catalyst via cannula. The reaction was stirred at room temperature under argon for $6 \mathrm{~h}$ at which time it was directly concentrated in vacuo. The resulting oily residue was purged with argon and dissolved in $2.0 \mathrm{~mL}$ degassed $\mathrm{DCM}$. $\mathrm{NEt}_{3}(0.031 \mathrm{~mL}, 0.22 \mathrm{~mol})$ was added followed by a solution of $\mathrm{Pd}_{2}(\mathrm{dba})_{3} \cdot \mathrm{CHCl}_{3}(4.1 \mathrm{mg}, 0.004 \mathrm{mmol})$ and $(R, R)-\mathbf{L}-\mathbf{1}(8.3 \mathrm{mg}, 0.0119 \mathrm{mmol})$ in $0.5 \mathrm{~mL}$ degassed DCM. The resulting red solution was stirred for $2 \mathrm{~h}$ at $0{ }^{\circ} \mathrm{C}$ at which point the mixture was concentrated in vacuo. The resulting oily residue was purified via flash chromatography ( silica, ether/petroleum ether, gradient) to yield $31 \mathrm{mg}(52 \%, 75 \%$ brsm) of 35 as a colorless oil. The diastereomeric ratio was determined to be 4.5:1 trans: cis by ${ }^{1} \mathrm{H}$ NMR $(500 \mathrm{MHz})$. $[\alpha]_{\mathrm{D}}-88.97$ (c $=0.05$ in $\left.\mathrm{CH}_{2} \mathrm{Cl}_{2}\right)$. IR (film from $\left.\mathrm{CDCl}_{3}\right): 2927,1630,1428,1248,1113,837,730,700 \mathrm{~cm}^{-1} .{ }^{1} \mathrm{H}$ NMR $\left(500 \mathrm{MHz}, \mathrm{CDCl}_{3}\right)$

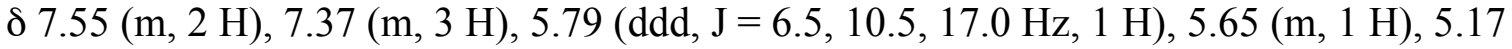
$(\mathrm{d}, \mathrm{J}=17.0 \mathrm{~Hz}, 1 \mathrm{H}), 5.07$ (d, J = 10.5 Hz, $1 \mathrm{H}), 4.49$ (m, $1 \mathrm{H}), 4.18$ (m, $1 \mathrm{H}), 2.86$ (ddt, J $=2.0,5.0,8.5 \mathrm{~Hz}, 1 \mathrm{H}), 2.43(\mathrm{~m}, 1 \mathrm{H}), 1.68-0.81(\mathrm{~m}, 11 \mathrm{H}), 0.37(\mathrm{~s}, 3 \mathrm{H}), 0.36(\mathrm{~s}, 3 \mathrm{H})$. ${ }^{13} \mathrm{C} \mathrm{NMR}\left(125 \mathrm{MHz}, \mathrm{CDCl}_{3}\right) \delta$ 162.20, 139.09, 138.96, 133.73 (2 C), 128.97, 127.80 (2 
C), 117.58, 115.09, 83.59, 78.24, 44.05, 43.54, 30.39, 26.70, 26.17 (2 C), 25.68, -1.18, 1.39. HRMS ( $\left.\mathrm{M}^{+}-\mathrm{H}\right) \mathrm{C}_{21} \mathrm{H}_{29} \mathrm{OSi}$. Calcd: 325.1988. Found 325.1985.

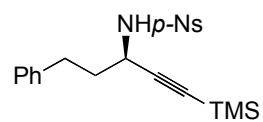

Compound 36. Step 1: DEAD $(0.14 \mathrm{~g}, 0.88 \mathrm{mmol})$ was added to a cooled $\left(0{ }^{\circ} \mathrm{C}\right)$ solution of $30(0.08 \mathrm{~g}, 0.35 \mathrm{mmol}), \mathrm{NH}(\mathrm{Boc}) \mathrm{Ns}(0.13 \mathrm{~g}, 0.42 \mathrm{mmol})$, and triphenylphosphine $(0.24 \mathrm{~g}, 0.92 \mathrm{mmol})$ in $1.2 \mathrm{~mL}$ THF. The resulting solution was stirred at room temperature overnight. The reaction was then concentrated in vacuo and purified directly via flash chromatography (silica, ether/petroleum ether, gradient) to yield $0.17 \mathrm{~g}(95 \%)$ of bis protected amine as a white solid. $\mathrm{mp}=129-132{ }^{\circ} \mathrm{C} . \mathrm{R}_{\mathrm{f}}=0.56$ in $30 \%$ ether/petroleum ether. $[\alpha]_{\mathrm{D}}+23.50\left(\mathrm{c}=2.13, \mathrm{CDCl}_{3}\right)$. Step 2: A solution of B-bromocatecholborane $(0.13$ $\mathrm{g}, 0.65 \mathrm{mmol})$ in $3.1 \mathrm{~mL}$ DCM was added to bisprotected amine $(0.16 \mathrm{~g}, 0.33 \mathrm{mmol})$ in $1.4 \mathrm{~mL}$ DCM. The reaction was stirred at room temperature for $1.5 \mathrm{~h}$ at which time 1.5 $\mathrm{mL} \mathrm{H}_{2} \mathrm{O}$ was added. The reaction was stirred an additional $20 \mathrm{~min}$. The resulting solution was diluted with DCM, washed 2 times with $10 \% \mathrm{NaOH}(\mathrm{aq})$ solution and once with brine. The organic layer was dried over magnesium sulfate, filtered, and concentrated in vacuo. The resulting oily solid was purified via flash chromatography (silica, ether/petroleum ether, gradient) to yield $1.07 \mathrm{~g} \mathrm{(78 \% )}$ of 36 as a white solid. $\mathrm{mp}=119$ $120{ }^{\circ} \mathrm{C} . \mathrm{R}_{\mathrm{f}}=0.28$ in $30 \%$ ether/petroleum ether. The solid was recrystallized from hot ether/hexanes to afford analytically pure crystals. The enantiomeric excess was determined to be 97\% by HPLC analysis. (Chiralcel OD column, 90:10 heptane:iPrOH, flow rate $=0.95 \mathrm{~mL} / \mathrm{min}, 254 \mathrm{~nm}, \mathrm{t}_{\mathrm{r}}: 12.53$ (major), 17.38 (minor)). $[\alpha]_{\mathrm{D}}+29.79(\mathrm{c}=$ 2.35, $\mathrm{CDCl}_{3}$ ). IR (film from $\mathrm{CDCl}_{3}$ ): 3284, 2959, 2175, 1532, 1424, 1349, 1167, 846, 738 $\mathrm{cm}^{-1} .{ }^{1} \mathrm{H}$ NMR $\left(300 \mathrm{MHz}, \mathrm{CDCl}_{3}\right) \delta 8.34(\mathrm{~d}, \mathrm{~J}=8.7 \mathrm{~Hz}, 2 \mathrm{H}), 8.06(\mathrm{~d}, \mathrm{~J}=9.0 \mathrm{~Hz}, 2 \mathrm{H})$, $7.24(\mathrm{~m}, 5 \mathrm{H}), 5.01$ (broad s, $1 \mathrm{H}), 4.12(\mathrm{~m}, 1 \mathrm{H}), 2.78$ (t, J = 7.5 Hz, $2 \mathrm{H}), 2.01$ (q, J = 7.5 $\mathrm{Hz}, 2 \mathrm{H}),-0.03(\mathrm{~s}, 9 \mathrm{H}) .{ }^{13} \mathrm{C} \mathrm{NMR}\left(75 \mathrm{MHz}, \mathrm{CDCl}_{3}\right) \delta 150.05,146.00,140.12,128.73(2$ C), 128.55 (3 C), 128.45, 126.31, 124.10 (2 C), 102.14, 90.46, 46.03, 38.22, 31.54, -0.50 (3 C). HRMS Calcd for $\mathrm{C}_{20} \mathrm{H}_{24} \mathrm{~N}_{2} \mathrm{O}_{4} \mathrm{SSi}$ : 416.1226. Found: 416.1211 .

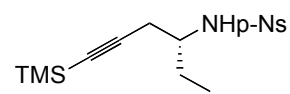

Compound 37. 4-Nitrobenzylsulfonylchloride $(3.2 \mathrm{~g}, 14.46 \mathrm{mmol})$ was added to a cooled $\left(0{ }^{\circ} \mathrm{C}\right)$ solution of $(R)$-2-amino-butan-1-ol $(0.52 \mathrm{~g}, 5.8 \mathrm{mmol})$ and $\mathrm{NEt}_{3}(2.17 \mathrm{~g}$, $21.5 \mathrm{mmol})$ in $20 \mathrm{~mL}$ DCM. The reaction was stirred at $0{ }^{\circ} \mathrm{C}$ for $5 \mathrm{~h}$ at which time it was quenched with water. The aqueous layer was extracted 2 times with DCM. The combined organic layers were washed with $10 \% \mathrm{NaHSO}_{3}$ followed by brine, dried over $\mathrm{MgSO}_{4}$, concentrated in vacuo and purified by flash chromatography to yield $0.94 \mathrm{~g}(63 \%)$ of $\mathrm{N}$ [(1R)-1-ethylbut-3-yn-1-yl]-4-nitrobenzenesulfonamide as a colorless oil. $\mathrm{R}_{\mathrm{f}}=0.58$ in $50 \%$ ether/petroleum ether. $n$-BuLi $(6.4 \mathrm{~mL}$ of $1.5 \mathrm{M}$ in hexanes) was added dropwise to a cooled $\left(-78^{\circ} \mathrm{C}\right)$ solution of TMS-acetylene $(0.94 \mathrm{~g}, 9.55 \mathrm{mmol})$ in $14 \mathrm{~mL}$ THF. The solution was stirred $20 \mathrm{~min}$ at $-78^{\circ} \mathrm{C}$. To the anion was added a cooled $\left(-78^{\circ} \mathrm{C}\right)$ solution of $N$-[(1R)-1-ethylbut-3-yn-1-yl]-4-nitrobenzenesulfonamide $(0.82 \mathrm{~g}, 3.18 \mathrm{mmol})$ in 7 $\mathrm{mL} \mathrm{THF}$ via cannula. The reaction was stirred while warming to room temperature 
overnight. The solution was quenched with saturated aq. $\mathrm{NH}_{4} \mathrm{Cl}$ and the aqueous layer was extracted 2 times with ether. The combined organics were washed with water, $\mathrm{NaHCO}_{3}$, and brine. The organic layer was dried over $\mathrm{MgSO}_{4}$, filtered, and concentrated in vacuo. The resulting oily residue was purified via flash chromatography to yield $0.79 \mathrm{~g}$ $(70 \%)$ of 37 as a white solid. $\mathrm{mp}=109-113{ }^{\circ} \mathrm{C} . \mathrm{R}_{\mathrm{f}}=0.52$ in $50 \%$ ether/pet ether. The solid was recrystallized from hot ether/petroluem ether to obtain analytically pure crystals, $3^{\text {rd }}$ crop recrystallization afforded $93 \%$ ee, $[\alpha]_{\mathrm{D}}+105.77\left(\mathrm{c}=1.66, \mathrm{CH}_{2} \mathrm{Cl}_{2}\right)$, as determined by chiral HPLC analysis. (Chiralcel OD column, 90:10 heptane:isopropanol, flow rate $=1.0 \mathrm{~mL} / \mathrm{min}, 254 \mathrm{~nm}, \tau_{\mathrm{R}}$ : 13.03(major), 14.20 (minor)). IR (film from $\mathrm{CH}_{2} \mathrm{Cl}_{2}$ ): 3290, 2966, 2177, 1532, 1426, 1350, 1167, 844, $614 \mathrm{~cm}^{-1} .{ }^{1} \mathrm{H}$ NMR $\left(300 \mathrm{MHz}, \mathrm{CDCl}_{3}\right) \delta$ $8.36(\mathrm{~d}, \mathrm{~J}=9.0 \mathrm{~Hz}, 2 \mathrm{H}), 8.08(\mathrm{~d}, \mathrm{~J}=9.0 \mathrm{~Hz}, 2 \mathrm{H}), 4.89$ (d, J = 9.0 Hz, $1 \mathrm{H}), 3.34$ (m, 1 H), $2.38(\mathrm{dd}, \mathrm{J}=17.1,3.9 \mathrm{~Hz}, 1 \mathrm{H}), 2.29$ (dd, $\mathrm{J}=17.1,5.7 \mathrm{~Hz}, 1 \mathrm{H}), 1.58$ (hept, $\mathrm{J}=7.2$ $\mathrm{Hz}, 2 \mathrm{H}), 0.82(\mathrm{t}, \mathrm{J}=7.2 \mathrm{~Hz}, 3 \mathrm{H}), 0.14(\mathrm{~s}, 9 \mathrm{H}) .{ }^{13} \mathrm{C} \mathrm{NMR}\left(125 \mathrm{MHz}, \mathrm{CDCl}_{3}\right) \delta$ 149.95, 146.97, 128.16 (2 C), 124.36 (2 C), 100.75, 88.92, 29.67, 27.15, 25.94, 10.20, -0.04 (3 C). Anal calcd for $\mathrm{C}_{15} \mathrm{H}_{22} \mathrm{~N}_{2} \mathrm{O}_{4} \mathrm{SSi}$ : C, 50.82\%; H, 6.26\%; N, 7.90\%. Found: C, 50.58\%; $\mathrm{H}, 6.38 \%$; N, 8.03\%.

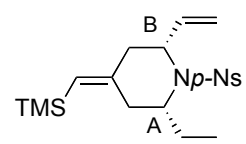

Compound 38. Note: starting 37 of $88 \%$ optical purity. Following Condition A: $\left[\mathrm{CpRu}\left(\mathrm{CH}_{3} \mathrm{CN}\right)_{3}\right] \mathrm{PF}_{6}(4 \mathrm{mg}, 0.009 \mathrm{mmol})$ was added to a flame-dried test tube under argon. A solution of $37(63 \mathrm{mg}, 0.18 \mathrm{mmol})$ and $15(0.59 \mathrm{~g}, 0.30 \mathrm{mmol})$ in degassed acetone $(0.9 \mathrm{~mL})$ was added to the catalyst via cannula. The reaction was stirred at room temperature under argon for $3 \mathrm{~h}$ at which time it was diluted with $2.2 \mathrm{~mL}$ degassed DCM. DBU $(28 \mathrm{mg}, 0.19 \mathrm{mmol})$ was added followed by a solution of $(\operatorname{Pd}(\pi \text {-allyl }) \mathrm{Cl})_{2}(1.4 \mathrm{mg}$, $0.0038 \mathrm{mmol})$ and $(S, S)$-L-1 $(7 \mathrm{mg}, 0.011 \mathrm{mmol})$ in $0.5 \mathrm{~mL}$ DCM. The resulting yellow solution was stirred for $1 \mathrm{~h}$ at room temperature at which point the mixture was concentrated in vacuo. The resulting oily residue was purified via flash chromatography (silica, $0-75 \%$ ether/petroleum ether, gradient) to yield $0.05 \mathrm{~g}(68 \%)$ of $\mathbf{3 8}$ as a white solid. $\mathrm{mp}=83-85^{\circ} \mathrm{C}$. With $88 \%$ ee at center $\mathrm{A},[\alpha]_{\mathrm{D}}+18.92\left(\mathrm{c}=0.78, \mathrm{CH}_{2} \mathrm{Cl}_{2}\right)$. Stereoisomeric ratios were determined via HPLC analysis. Chiralcel OD column. Flow rate $=1.0 \mathrm{~mL} / \mathrm{min} .99: 1$ heptane:2-propanol. $254 \mathrm{~nm} . \tau_{\mathrm{r}}=16.61$ (minor - mismatched isomer), 18.15 (major - mismatched isomer), 23.11 (minor - matched isomer), 24.20(major - matched isomer). Weak nOe between $\mathrm{H}_{\mathrm{A}}$ and $\mathrm{H}_{\mathrm{B}}$ was observed on a 500 $\mathrm{MHz}$ Varian NMR. IR (film from $\mathrm{Et}_{2} \mathrm{O}$ ): 2964, 1533, 1350, 1250, 1166, 843, $736 \mathrm{~cm}^{-1}$. ${ }^{1} \mathrm{H}$ NMR (500 MHz, $\left.\mathrm{CDCl}_{3}\right) \delta 8.35(\mathrm{~d}, \mathrm{~J}=9.0 \mathrm{~Hz}, 2 \mathrm{H}), 8.05(\mathrm{~d}, \mathrm{~J}=9.0 \mathrm{~Hz}, 2 \mathrm{H}), 5.90$ (ddd, J = 17.1, 10.5, 6.0 Hz, $1 \mathrm{H}), 5.38(\mathrm{~s}, 1 \mathrm{H}), 5.27(\mathrm{~d}, \mathrm{~J}=17.1 \mathrm{~Hz}, 1 \mathrm{H}), 5.14(\mathrm{~d}, \mathrm{~J}=$ $10.2 \mathrm{~Hz}, 1 \mathrm{H}), 4.67$ (m, $1 \mathrm{H}), 4.07$ (q, J = 6.9 Hz, $1 \mathrm{H}), 2.30$ (m, $2 \mathrm{H}), 2.16$ (dd, J = 13.5, $6.3 \mathrm{~Hz}, 1 \mathrm{H}), 2.00(\mathrm{dd}, \mathrm{J}=13.5,6.3 \mathrm{~Hz}, 1 \mathrm{H}), 1.59(\mathrm{~m}, 1 \mathrm{H}), 1.42(\mathrm{~m}, 1 \mathrm{H}), 0.91$ (t, J = $7.5 \mathrm{~Hz}, 3 \mathrm{H}), 0.06$ (s, $9 \mathrm{H}) .{ }^{13} \mathrm{C}$ NMR $\left(125 \mathrm{MHz} \mathrm{CDCl}_{3}\right) \delta 149.75,147.45,145.98$, 137.77, 129.31, 127.99 (2 C), 124.41 (2 C), 117.44, 56.92, 55.39, 40.90, 35.69, 27.73, 11.56, 0.19 (3 C). Anal calcd for $\mathrm{C}_{19} \mathrm{H}_{28} \mathrm{~N}_{2} \mathrm{O}_{4} \mathrm{SSi}$ : C, 55.85\%; H, 6.91\%, N, 6.86\%.

Found: C, 56.02; H, 7.06; N, 6.64\%. 


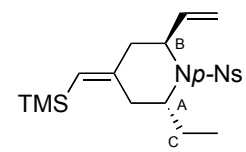

Compound 39. Note: starting 37 of $93 \%$ optical purity. Following Condition A: $\left[\mathrm{CpRu}\left(\mathrm{CH}_{3} \mathrm{CN}\right)_{3}\right] \mathrm{PF}_{6}(4 \mathrm{mg}, 0.01 \mathrm{mmol})$ was added to a flame-dried test tube under argon. A solution of $37(71 \mathrm{mg}, 0.2 \mathrm{mmol})$ and $15(65 \mathrm{mg}, 0.33 \mathrm{mmol})$ in degassed acetone $(1.0 \mathrm{~mL})$ was added to the catalyst via cannula. The reaction was stirred at room temperature under argon for $3 \mathrm{~h}$ at which time it was diluted with $2.5 \mathrm{~mL}$ degassed DCM. $\mathrm{DBU}(30 \mathrm{mg}, 0.20 \mathrm{mmol})$ was added followed by a solution of $(\mathrm{Pd}(\pi \text {-allyl }) \mathrm{Cl})_{2}(1.5 \mathrm{mg}$, $0.004 \mathrm{mmol})$ and $(R, R)-\mathbf{L}-1(8 \mathrm{mg}, 0.012 \mathrm{mmol})$ in $0.5 \mathrm{~mL}$ DCM. The resulting yellow solution was stirred for $1 \mathrm{~h}$ at room temperature at which point the mixture was concentrated in vacuo. The resulting oily residue was purified via flash chromatography (silica, $0-75 \%$ ether/petroleum ether, gradient) to yield $98 \mathrm{mg}(73 \%)$ of $\mathbf{3 9}$ as an oily white solid. With 93\%ee at center A, $[\alpha]_{\mathrm{D}}+32.60\left(\mathrm{c}=0.18, \mathrm{CH}_{2} \mathrm{Cl}_{2}\right)$. Stereoisomeric ratios were determined via HPLC analysis. Chiralcel OD column. Flow rate $=1.0$ $\mathrm{mL} / \mathrm{min} .99: 1$ heptane:2-propanol. $254 \mathrm{~nm} . \tau_{\mathrm{r}}=16.61$ (major - mismatched isomer), 18.15 (minor mismatched isomer), 23.11 (major - matched isomer), 24.20 (minor matched isomer). 3.7\% nOe was observed between $\mathrm{H}_{\mathrm{B}}$ and $\mathrm{H}_{\mathrm{C}}$ on a $500 \mathrm{MHz}$ Varian NMR. IR (film from $\mathrm{CD}_{3} \mathrm{CN}$ ): 2956, 1618, 1350, 1164, 855, $741 \mathrm{~cm}^{-1} .{ }^{1} \mathrm{H}$ NMR (300 $\left.\mathrm{MHz}, \mathrm{CDCl}_{3}\right) \delta 8.20(\mathrm{~d}, \mathrm{~J}=9.0 \mathrm{~Hz}, 2 \mathrm{H}), 7.90(\mathrm{~d}, \mathrm{~J}=9.0 \mathrm{~Hz}, 2 \mathrm{H}), 5.74$ (ddd, J = 17.1, 9.9, $7.5 \mathrm{~Hz}, 1 \mathrm{H}), 5.29$ (s, $1 \mathrm{H}), 5.04$ (d, J = 17.1 Hz, $1 \mathrm{H}), 4.97$ (d, J = 9.9 Hz, $1 \mathrm{H}), 4.01$ (m, $2 \mathrm{H}), 2.41(\mathrm{~m}, 4 \mathrm{H}), 1.62(\mathrm{~m}, 1 \mathrm{H}), 1.45(\mathrm{~m}, 1 \mathrm{H}), 0.79(\mathrm{t}, \mathrm{J}=7.5 \mathrm{~Hz}, 3 \mathrm{H}), 0.00(\mathrm{~s}, 9$ $\mathrm{H}) .{ }^{13} \mathrm{C} \mathrm{NMR}\left(75 \mathrm{MHz}, \mathrm{CDCl}_{3}\right) \delta 149.60,148.66,148.11,136.81,128.57$ (2 C), 128.07, 123.94 (2 C), 118.29, 57.62 (2 C), 43.17, 35.69, 26.00, 11.34, 0.09 (3 C). Anal calcd for $\mathrm{C}_{19} \mathrm{H}_{28} \mathrm{~N}_{2} \mathrm{O}_{4} \mathrm{SSi}: \mathrm{C}, 55.85 \%$; H, 6.91\%. Found: C, 55.63\%; H, 6.84\%.

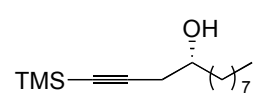

Compound 40. Step 1: The resolution of racemic epoxide was performed in analogy to a literature procedure. ${ }^{9} \mathrm{AcOH}(0.02 \mathrm{~g}, 0.35 \mathrm{mmol})$ was added to a solution of $(R, R)$ Salen $(\mathrm{Co})^{\mathrm{II}}(0.10 \mathrm{~g}, 0.17 \mathrm{mmol})$ in $1.5 \mathrm{~mL}$ toluene. The reaction was stirred at room temperature, open to air for $1 \mathrm{~h}$. The solution was concentrated in vacuo and dried under high vacuum. The resulting residue was diluted with $5 \mathrm{~mL}$ diethyl ether. ( $\mathrm{rac}$ )-2-Nonyloxirane $(2.6 \mathrm{~g}, 16.7 \mathrm{mmol})$ was added to the catalyst solution followed by the addition of water $(0.15 \mathrm{~g}, 8.3 \mathrm{mmol})$. The reaction was stirred at room temperature for 3 days at which time it was concentrated in vacuo and purified via flash chromatography (silica, ether/petroleum ether) to yield $1.1 \mathrm{~g}(43 \%)$ of $(R)$-2-nonyl-oxirane as a colorless oil. The spectra matched literature data. ${ }^{10}$ Step $2: n$-BuLi (10.6 mL of $1.6 \mathrm{M}$ in hexanes) was added to a cooled $\left(-78^{\circ} \mathrm{C}\right)$ solution of trimethylsilyl acetylene $(1.74 \mathrm{~g}, 17.7 \mathrm{mmol})$ in 35 $\mathrm{mL}$ THF. The solution was stirred for 20 min while warming slowly to no higher than 0 ${ }^{\circ} \mathrm{C}$ at which time it is cooled to $-78{ }^{\circ} \mathrm{C}$. $(R)$-2-Nonyl-oxirane $(1.1 \mathrm{~g}, 7.04 \mathrm{mmol})$ was added followed by $\mathrm{BF}_{3} \mathrm{OEt}_{2}(2.0 \mathrm{~g}, 14.2 \mathrm{mmol})$. The reaction was stirred at $-78^{\circ} \mathrm{C}$ for 3 $\mathrm{h}$, quenched with saturated aq. ammonium chloride, and warm to room temperature. The aqueous layer was extracted 3 times with ether. The combined organic layers were 
washed with brine, dried over magnesium sulfate, filtered, and concentrate in vacuo. The resulting oily residue was purified via flash chromatography (silica, ether/petroleum ether) to yield $1.3 \mathrm{~g}(75 \%)$ of $\mathbf{4 0}$ as a colorless oil. The enantiomeric excess was determined to be $99 \%$ via HPLC analysis of a derivative $(\mathbf{8 0}) .[\alpha]_{\mathrm{D}}-3.82(\mathrm{c}=1.66$, $\left.\mathrm{CH}_{2} \mathrm{Cl}_{2}\right) . \mathrm{R}_{\mathrm{f}}=0.46$ in $25 \%$ ether/petroleum ether. IR (neat): 3374, 2927, 2858, 2176, 1250, 843, $760 \mathrm{~cm}^{-1} .{ }^{1} \mathrm{H}$ NMR $\left(500 \mathrm{MHz}, \mathrm{CDCl}_{3}\right) \delta 3.76(\mathrm{~m}, 1 \mathrm{H}), 2.48(\mathrm{dd}, \mathrm{J}=16.5,4.5$ $\mathrm{Hz}, 1 \mathrm{H}), 2.37$ (dd, J = 16.5, 7.0 Hz, $1 \mathrm{H}), 1.53$ (m, $2 \mathrm{H}), 1.45$ (m, $1 \mathrm{H}), 1.30(\mathrm{~m}, 12 \mathrm{H})$, $0.90(\mathrm{t}, \mathrm{J}=7.0 \mathrm{~Hz}, 3 \mathrm{H}), 0.18(\mathrm{~s}, 9 \mathrm{H}) .{ }^{13} \mathrm{C} \mathrm{NMR}\left(125 \mathrm{MHz}, \mathrm{CDCl}_{3}\right) \delta 103.31,87.51$, 69.84, 36.18, 31.84, 29.50, 29.48, 29.23, 28.84, 25.54, 22.64, 14.08, 0.04 (3 C). Anal calcd for $\mathrm{C}_{15} \mathrm{H}_{30} \mathrm{OSi}$ : C, 70.79\%; H, 11.88\%. Found: C, 70.86\%, H, 11.68\%.

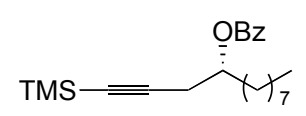

Compound 80. Benzoyl chloride ( $44 \mu \mathrm{L}, 0.31 \mathrm{mmol})$ was added to a cooled $\left(0{ }^{\circ} \mathrm{C}\right)$ solution of 40 (37 mg, $0.15 \mathrm{mmol})$, triethylamine $(0.07 \mathrm{~mL}, 0.5 \mathrm{mmol})$, and DMAP (12 $\mathrm{mg}, 0.10 \mathrm{mmol}$ ) in $0.9 \mathrm{~mL}$ DCM. The resulting solution was stirred $1 \mathrm{~h}$ at room temperature at which time it was quenched with saturated aq. ammonium chloride. The aqueous layer was extracted 2 times with DCM, dried over magnesium sulfate, filtered, and concentrated in vacuo. The resulting oily residue was purified via flash chromatography (silica, ether/petroleum ether, gradient) to yield $51 \mathrm{mg}(96 \%)$ of $\mathbf{8 0}$ as a colorless oil. $\mathrm{R}_{\mathrm{f}}=0.7$ in 1:5 ether:petroleum ether. The enantoimeric excess was determined to be $99 \%$ by HPLC analysis. (Chiralcel OD column, 99.9:0.1 heptane:iPrOH, flow rate $=1.0 \mathrm{~mL} / \mathrm{min}, 254 \mathrm{~nm}, \mathrm{t}_{\mathrm{r}}: 6.69$ (minor), 8.13 (major)). $[\alpha]_{\mathrm{D}}+$ 24.32 (c = 1.71, $\mathrm{CH}_{2} \mathrm{Cl}_{2}$ ). IR (neat): 2926, 2856, 2179, 1722, 1271, 1250, 1110, 842, 710 $\mathrm{cm}^{-1} .{ }^{1} \mathrm{H}$ NMR $\left(300 \mathrm{MHz}, \mathrm{CDCl}_{3}\right) \delta 7.90(\mathrm{~d}, \mathrm{~J}=8.4 \mathrm{~Hz}, 2 \mathrm{H}), 7.40(\mathrm{t}, \mathrm{J}=7.5 \mathrm{~Hz}, 1 \mathrm{H})$, 7.28 (t, J = 7.5 Hz, $2 \mathrm{H}), 5.03(\mathrm{p}, \mathrm{J}=6.3 \mathrm{~Hz}, 1 \mathrm{H}), 2.46-2.35(\mathrm{~m}, 2 \mathrm{H}), 1.66(\mathrm{~m}, 2 \mathrm{H}), 1.10$ $(\mathrm{m}, 12 \mathrm{H}), 0.71(\mathrm{t}, \mathrm{J}=6.9 \mathrm{~Hz}, 3 \mathrm{H}),-0.04(\mathrm{~s}, 9 \mathrm{H}) .{ }^{13} \mathrm{C} \mathrm{NMR}\left(75 \mathrm{MHz}, \mathrm{CDCl}_{3}\right) \delta 166.01$, 132.84 (2 C), 130.46, 129.62 (2 C), 128.24 (2 C), 102.29, 87.05, 72.42, 33.12, 31.81, 29.33, 29.17, 25.47, 25.13, 22.62, 14.06, -0.12 (3 C). Anal calcd for $\mathrm{C}_{22} \mathrm{H}_{34} \mathrm{O}_{2} \mathrm{Si}: \mathrm{C}$, $73.69 \%$; H, 9.56\%. Found: C, 73.53\%; H, 9.29\%.

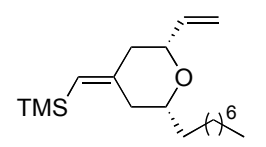

Compound 41. For Condition $\mathrm{D}$ : $\left[\mathrm{CpRu}\left(\mathrm{CH}_{3} \mathrm{CN}\right)_{3}\right] \mathrm{PF}_{6}(8.7 \mathrm{mg}, 0.02 \mathrm{mmol})$ was added to a flame-dried test tube under argon. A solution of $\mathbf{4 0}(51 \mathrm{mg}, 0.2 \mathrm{mmol})$ and $\mathbf{1 5}(0.22$ $\mathrm{g}, 1.1 \mathrm{mmol})$ in degassed acetone $(1.0 \mathrm{~mL})$ was added to the catalyst via cannula. The reaction was stirred at room temperature under argon for $6 \mathrm{~h}$ at which time it was directly concentrated in vacuo. The resulting oily residue was purged with argon and dissolved in $2.0 \mathrm{~mL}$ degassed DCM. $\mathrm{NEt}_{3}(0.031 \mathrm{~mL}, 0.22 \mathrm{mmol})$ was added followed by a solution of $\mathrm{Pd}_{2}(\mathrm{dba})_{3} \cdot \mathrm{CHCl}_{3}(4.1 \mathrm{mg}, 0.004 \mathrm{mmol})$ and $(R, R)-\mathbf{L}-\mathbf{1}(8.3 \mathrm{mg}, 0.012 \mathrm{mmol})$ in $0.5 \mathrm{~mL}$ degassed DCM. The resulting red solution was stirred for $2 \mathrm{~h}$ at $0{ }^{\circ} \mathrm{C}$ at which point the mixture was concentrated in vacuo. The resulting oily residue was purified via 
flash chromatography (silica, $0-50 \%$ ether/petroleum ether, gradient) to yield $49 \mathrm{mg}$ $(80 \%)$ of 41 as a colorless oil. $[\alpha]_{\mathrm{D}}-13.35\left(\mathrm{c}=2.34, \mathrm{CH}_{2} \mathrm{Cl}_{2}\right)$. IR (film from $\left.\mathrm{CDCl}_{3}\right)$ : 2927, 2856, 1623, 1248, 1142, 1066, $840 \mathrm{~cm}^{-1} .{ }^{1} \mathrm{H}$ NMR (500 MHz, $\left.\mathrm{CDCl}_{3}\right) \delta 5.90$ (ddd, $\mathrm{J}=5.5,10.5,16.5 \mathrm{~Hz}, 1 \mathrm{H}), 5.27(\mathrm{~m}, 2 \mathrm{H}), 5.14(\mathrm{~d}, \mathrm{~J}=10.5 \mathrm{~Hz}, 1 \mathrm{H}), 3.84(\mathrm{~m}, 1 \mathrm{H}), 3.28$ $(\mathrm{m}, 1 \mathrm{H}), 2.47(\mathrm{dt}, \mathrm{J}=13.5,2.0 \mathrm{~Hz}, 1 \mathrm{H}), 2.22(\mathrm{~m}, 2 \mathrm{H}), 1.89(\mathrm{t}, \mathrm{J}=12.5 \mathrm{~Hz}, 1 \mathrm{H}), 1.66$ $(\mathrm{m}, 1 \mathrm{H}), 1.47(\mathrm{~m}, 1 \mathrm{H}), 1.35(\mathrm{~m}, 12 \mathrm{H}), 0.90(\mathrm{t}, \mathrm{J}=6.5 \mathrm{~Hz}, 3 \mathrm{H}), 0.13(\mathrm{~s}, 9 \mathrm{H}) .{ }^{13} \mathrm{C} \mathrm{NMR}$ $\left(125 \mathrm{MHz}, \mathrm{CDCl}_{3}\right) \delta 153.73,138.85,122.89,115.04,79.22,78.35,45.34,39.88,36.39$, $31.86,29.67,29.52,29.28,25.50,22.66,14.11,0.32$ (3 C). Anal calcd for $\mathrm{C}_{19} \mathrm{H}_{36} \mathrm{OSi}: \mathrm{C}$, $73.95 \%$; H, 11.76\%. Found: C, 74.17\%; H, 11.60\%.

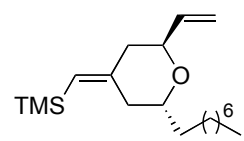

Compound 42. For Condition D: $\left[\mathrm{CpRu}\left(\mathrm{CH}_{3} \mathrm{CN}\right)_{3}\right] \mathrm{PF}_{6}(8.7 \mathrm{mg}, 0.02 \mathrm{mmol})$ was added to a flame-dried test tube under argon. A solution of $\mathbf{4 0}(51 \mathrm{mg}, 0.20 \mathrm{mmol})$ and $15(0.22$ $\mathrm{g}, 1.1 \mathrm{mmol})$ in degassed acetone $(1.0 \mathrm{~mL})$ was added to the catalyst via cannula. The reaction was stirred at room temperature under argon for $6 \mathrm{~h}$ at which time it was directly concentrated in vacuo. The resulting oily residue was purged with argon and dissolved in $2.0 \mathrm{~mL}$ degassed $\mathrm{DCM}$. $\mathrm{NEt}_{3}(0.031 \mathrm{~mL}, 0.22 \mathrm{mmol})$ was added followed by a solution of $\mathrm{Pd}_{2}(\mathrm{dba})_{3} \cdot \mathrm{CHCl}_{3}(4.1 \mathrm{mg}, 0.004 \mathrm{mmol})$ and $(S, S)-\mathbf{L}-\mathbf{1}(8.3 \mathrm{mg}, 0.012 \mathrm{mmol})$ in $0.5 \mathrm{~mL}$ degassed $\mathrm{DCM}$. The resulting red solution was stirred for $2 \mathrm{~h}$ at $0{ }^{\circ} \mathrm{C}$ at which point the mixture was concentrated in vacuo. The resulting oily residue was purified via flash chromatography (silica, $0-50 \%$ ether/petroleum ether, gradient) to yield $48 \mathrm{mg}$ $(80 \%)$ of 42 as an colorless oil. $[\alpha]_{\mathrm{D}}+42.16\left(\mathrm{c}=2.04, \mathrm{CH}_{2} \mathrm{Cl}_{2}\right)$. IR (film from $\mathrm{CDCl}_{3}$ ): 2928, 2856, 1623, 1248, 1053, 869, $841 \mathrm{~cm}^{-1} .{ }^{1} \mathrm{H}$ NMR $\left(500 \mathrm{MHz}, \mathrm{CDCl}_{3}\right) \delta 5.90$ (ddd, J $=5.5,10.5,16.5 \mathrm{~Hz}, 1 \mathrm{H}), 5.28(\mathrm{~d}, \mathrm{~J}=16.5 \mathrm{~Hz}, 1 \mathrm{H}), 5.23(\mathrm{~s}, 1 \mathrm{H}), 5.18(\mathrm{~d}, \mathrm{~J}=10.5 \mathrm{~Hz}$, $1 \mathrm{H}), 5.29(\mathrm{q}, \mathrm{J}=5.5 \mathrm{~Hz}, 1 \mathrm{H}), 3.82(\mathrm{~m}, 1 \mathrm{H}), 2.45$ (dd, J = 13.5, $4.0 \mathrm{~Hz}, 2 \mathrm{H}), 2.24$ (dd, J $=13.5,6.5 \mathrm{~Hz}, 1 \mathrm{H}), 2.12(\mathrm{dd}, \mathrm{J}=13.5,6.5 \mathrm{~Hz}, 1 \mathrm{H}), 1.66(\mathrm{~m}, 1 \mathrm{H}), 1.35(\mathrm{~m}, 1 \mathrm{H}), 1.29$ $(\mathrm{m}, 12 \mathrm{H}), 0.90(\mathrm{t}, \mathrm{J}=9.0 \mathrm{~Hz}, 3 \mathrm{H}), 0.12(\mathrm{~s}, 9 \mathrm{H}) .{ }^{13} \mathrm{C} \mathrm{NMR}\left(125 \mathrm{MHz}, \mathrm{CDCl}_{3}\right) \delta$ 151.26, 138.25, 124.66, 116.32, 72.91, 72.44, 43.85, 38.81, 33.73, 31.84, 29.57, 29.55, 29.26, $25.55,22.65,14.10,0.30$ (3 C). Anal calcd for $\mathrm{C}_{19} \mathrm{H}_{36} \mathrm{OSi}$ : C, 73.95\%; H, 11.76\%.

Found: C, 73.82\%; H, 11.61\%.

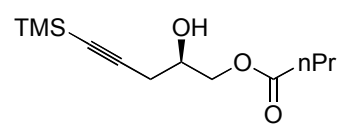

Compound 43. $n$-Butyllithium (11.6 $\mathrm{mL}$ of $1.46 \mathrm{M}$ in hexanes) was added to a cooled ($\left.78{ }^{\circ} \mathrm{C}\right)$ solution of trimethylsilyl acetylene $(1.7 \mathrm{~g}, 17.7 \mathrm{mmol})$ in $40 \mathrm{~mL}$ THF. The solution was stirred for $20 \mathrm{~min}$ while warming slowly to no higher than $0{ }^{\circ} \mathrm{C}$ at which time it was cooled to $-78^{\circ} \mathrm{C}$. $(R)$-Butyric acid oxiranylmethyl ester $(1.2 \mathrm{~g}, 15.2 \mathrm{mmol})$ was added followed by $\mathrm{BF}_{3} \cdot \mathrm{OEt}_{2}(2.2 \mathrm{~g}, 15.3 \mathrm{mmol})$. The reaction was stirred at $-78{ }^{\circ} \mathrm{C}$ for $3 \mathrm{~h}$ and quenched with saturated aq. ammonium chloride. The aqueous layer was extracted 3 times with ether. The combined organic layers were washed with brine, dried over magnesium sulfate, filtered, and concentrated in vacuo. The resulting oily residue was purified via flash chromatography (silica, ether/petroleum ether, gradient) to yield 
$2.7 \mathrm{~g}(74 \%)$ of $\mathbf{4 3}$ as a colorless oil. $\mathrm{R}_{\mathrm{f}}=0.41$ in $30 \%$ ether/petroleum ether. The enantiomeric excess was determined to be $99 \%$ via HPLC analysis of a derivative (81). $[\alpha]_{\mathrm{D}}-10.57\left(\mathrm{c}=2.23, \mathrm{CH}_{2} \mathrm{Cl}_{2}\right)$. IR (neat): 3462, 2963, 2177, 1741, 1250, 1179, 1100, $844,760 \mathrm{~cm}^{-1} .{ }^{1} \mathrm{H}$ NMR $\left(300 \mathrm{MHz}, \mathrm{CDCl}_{3}\right) \delta 4.05(\mathrm{dd}, \mathrm{J}=11.4,3.9 \mathrm{~Hz}, 1 \mathrm{H}), 3.96(\mathrm{dd}, \mathrm{J}$ = 11.4, $6.3 \mathrm{~Hz}, 1 \mathrm{H}), 3.83(\mathrm{~m}, 1 \mathrm{H}), 2.34(\mathrm{~d}, \mathrm{~J}=6.3 \mathrm{~Hz}, 2 \mathrm{H}), 2.24(\mathrm{~d}, \mathrm{~J}=4.8 \mathrm{~Hz}, 1 \mathrm{H})$, 2.18 (t, J = 7.5 Hz, $2 \mathrm{H}), 1.51$ (qt, J = 7.5, 7.5 Hz, $2 \mathrm{H}), 0.79$ (t, J = 7.5 Hz, $3 \mathrm{H}),-0.01$ (s, $9 \mathrm{H}) .{ }^{13} \mathrm{C}$ NMR $\left(75 \mathrm{MHz}, \mathrm{CDCl}_{3}\right) \delta$ 173.77, 101.48, 88.08, 68.15, 66.77, 35.97, 25.21, $18.35,13.61,-0.07(3 \mathrm{C})$. Anal calcd for $\mathrm{C}_{12} \mathrm{H}_{22} \mathrm{O}_{3} \mathrm{Si}: \mathrm{C}, 59.46 \% ; \mathrm{H}, 9.15 \%$. Found: $\mathrm{C}$, $59.60 \% ; \mathrm{H}, 9.26 \%$.

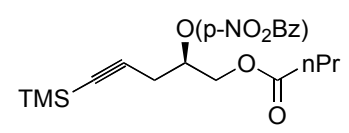

Compound 81. A solution of DCC (50 mg, 0.24mmol) and DMAP (17 mg, $0.14 \mathrm{mmol})$ in $0.2 \mathrm{~mL}$ DCM was added to a cooled $\left(0{ }^{\circ} \mathrm{C}\right)$ solution of $\mathbf{4 3}(36 \mathrm{mg}, 0.15 \mathrm{mmol})$ and $4-$ nitrobenzoic acid ( $40 \mathrm{mg}, 0.24 \mathrm{mmol}$ ) in $0.4 \mathrm{~mL}$ DCM. The resulting off-white slurry was stirred at room temperature overnight. The mixture was then eluted through a plug of celite with DCM. The filtrate was washed 2 times with $1 \mathrm{M} \mathrm{HCl}$ and once with brine. The organic layer was dried over magnesium sulfate, filtered, and concentrated in vacuo. The resulting oily residue was purified via flash chromatography (silica, ether/petroleum ether, gradient) to yield $49 \mathrm{mg}(84 \%)$ of $\mathbf{8 1}$ as a colorless oil. The enantiomeric excess was determined to be $99 \%$ via HPLC analysis. (Chiralcel OD column, $98: 2$ heptane:iPrOH, flow rate $=1.0 \mathrm{~mL} / \mathrm{min}, 254 \mathrm{~nm}, \mathrm{t}_{\mathrm{r}}: 11.76$ (major), 13.26 (minor)). $[\alpha]_{\mathrm{D}}$ $-11.76\left(\mathrm{c}=1.40, \mathrm{CH}_{2} \mathrm{Cl}_{2}\right.$ ). IR (neat): 2924, 2181, 1734, 1531, 1350, 1273, 1171, 1016, $844 \mathrm{~cm}^{-1} .{ }^{1} \mathrm{H}$ NMR $\left(300 \mathrm{MHz}, \mathrm{CDCl}_{3}\right) \delta 8.14(\mathrm{~d}, \mathrm{~J}=9.0 \mathrm{~Hz}, 2 \mathrm{H}), 8.05(\mathrm{~d}, \mathrm{~J}=9.0 \mathrm{~Hz}, 2$ $\mathrm{H}), 5.26(\mathrm{~m}, 1 \mathrm{H}), 4.32(\mathrm{dd}, \mathrm{J}=12.0,3.6 \mathrm{~Hz}, 1 \mathrm{H}), 4.23(\mathrm{dd}, \mathrm{J}=12.0,6.6 \mathrm{~Hz}, 1 \mathrm{H}), 2.57$ (d, J = 6.3 Hz, 2 H), 2.15 (t, J=7.5 Hz, $2 \mathrm{H}), 2.47$ (qt, J = 7.5, 7.5 Hz, $2 \mathrm{H}), 0.76$ (t, J = $7.5 \mathrm{~Hz}, 3 \mathrm{H}),-0.48(\mathrm{~s}, 9 \mathrm{H}) .{ }^{13} \mathrm{C}$ NMR $\left(75 \mathrm{MHz}, \mathrm{CDCl}_{3}\right) \delta 173.13,163.79,150.64$, 135.15, 130.85 (2 C), 123.53 (2 C), 100.02, 88.29, 71.06, 63.39, 35.89, 22.34, 18.32, 13.57, -0.20 (3 C). Anal calcd for $\mathrm{C}_{19} \mathrm{H}_{25} \mathrm{NO}_{6} \mathrm{Si}$ : C, $58.29 \%$; H, 6.44\%; N, 3.58\%. Found: C, $58.48 \%$; H, 6.65\%; N, 3.56\%.

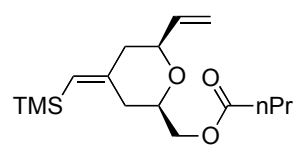

Compound 44. For Condition D: $\left[\mathrm{CpRu}\left(\mathrm{CH}_{3} \mathrm{CN}\right)_{3}\right] \mathrm{PF}_{6}(8.7 \mathrm{mg}, 0.02 \mathrm{mmol})$ was added to a flame-dried test tube under argon. A solution of $43(48 \mathrm{mg}, 0.20 \mathrm{mmol})$ and $15(0.22$ $\mathrm{g}, 1.1 \mathrm{mmol})$ in degassed acetone $(1.0 \mathrm{~mL})$ was added to the catalyst via cannula. The reaction was stirred at room temperature under argon for $6 \mathrm{~h}$ at which time it was directly concentrated in vacuo. The resulting oily residue was purged with argon and dissolved in $2.0 \mathrm{~mL}$ degassed DCM. NEt $3(0.031 \mathrm{~mL}, 0.22 \mathrm{mmol})$ was added followed by a solution of $\mathrm{Pd}_{2}(\mathrm{dba})_{3} \cdot \mathrm{CHCl}_{3}(4.1 \mathrm{mg}, 0.004 \mathrm{mmol})$ and $(S, S)-\mathbf{L}-1(8.3 \mathrm{mg}, 0.012 \mathrm{mmol})$ in $0.5 \mathrm{~mL}$ degassed DCM. The resulting red solution was stirred for $2 \mathrm{~h}$ at $0{ }^{\circ} \mathrm{C}$ at which point the mixture was concentrated in vacuo. The resulting oily residue was purified via flash chromatography (silica, $0-50 \%$ ether/petroleum ether, gradient) to yield $30 \mathrm{mg}$ 
(58\%) of 44 as a colorless oil. $[\alpha]_{\mathrm{D}}+5.85\left(\mathrm{c}=1.10, \mathrm{CH}_{2} \mathrm{Cl}_{2}\right)$. IR (film from $\left.\mathrm{CDCl}_{3}\right)$ : $2956,1742,1624,1249,1178,841 \mathrm{~cm}^{-1} .{ }^{1} \mathrm{H}$ NMR $\left(300 \mathrm{MHz}, \mathrm{CDCl}_{3}\right) \delta 5.90$ (ddd, J = 10.2, 6.3, $3.3 \mathrm{~Hz}, 1 \mathrm{H}), 5.34(\mathrm{~s}, 1 \mathrm{H}), 5.29(\mathrm{~d}, \mathrm{~J}=10.2 \mathrm{~Hz}, 1 \mathrm{H}), 5.16(\mathrm{~d}, \mathrm{~J}=6.3 \mathrm{~Hz}, 1 \mathrm{H})$, 4.20 (dd, J = 6.9, 3.9 Hz, $1 \mathrm{H}), 4.14(\mathrm{dd}, \mathrm{J}=6.9,2.7 \mathrm{~Hz}, 1 \mathrm{H}), 3.88(\mathrm{~m}, 1 \mathrm{H}), 3.56(\mathrm{~m}, 1$ H), $2.46(\mathrm{~d}, \mathrm{~J}=8.1 \mathrm{~Hz}, 1 \mathrm{H}), 2.35(\mathrm{t}, \mathrm{J}=4.5 \mathrm{~Hz}, 2 \mathrm{H}), 2.33(\mathrm{~m}, 2 \mathrm{H}), 2.00(\mathrm{t}, \mathrm{J}=7.5 \mathrm{~Hz}, 1$ $\mathrm{H}), 1.69(\mathrm{dt}, \mathrm{J}=4.5,4.5 \mathrm{~Hz}, 2 \mathrm{H}), 0.98(\mathrm{t}, \mathrm{J}=4.5 \mathrm{~Hz}, 3 \mathrm{H}), 0.13(\mathrm{~s}, 9 \mathrm{H}) .{ }^{13} \mathrm{C}$ NMR $(75$ $\left.\mathrm{MHz}, \mathrm{CDCl}_{3}\right) \delta 173.47,151.88,138.29,124.26,115.43,79.33,75.75,66.55,45.08$, $36.27,36.06,18.39,13.64,0.22$ (3 C). Anal calcd for $\mathrm{C}_{16} \mathrm{H}_{28} \mathrm{O}_{3} \mathrm{Si}$ : C, $64.82 \% ; \mathrm{H}, 9.52 \%$. Found: C, $64.60 \%$; $\mathrm{H}, 9.26 \%$.

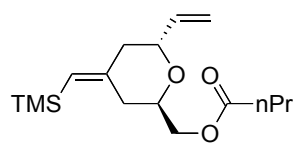

Compound 45. For Condition D: $\left[\mathrm{CpRu}\left(\mathrm{CH}_{3} \mathrm{CN}\right)_{3}\right] \mathrm{PF}_{6}(8.7 \mathrm{mg}, 0.02 \mathrm{mmol})$ was added to a flame-dried test tube under argon. A solution of $\mathbf{4 3}(4.8 \mathrm{mg}, 0.20 \mathrm{mmol})$ and $\mathbf{1 5}(0.22$ $\mathrm{g}, 1.1 \mathrm{mmol})$ in degassed acetone $(1.0 \mathrm{~mL})$ was added to the catalyst via cannula. The reaction was stirred at room temperature under argon for $6 \mathrm{~h}$ at which time it was directly concentrated in vacuo. The resulting oily residue was purged with argon and dissolved in $2.0 \mathrm{~mL}$ degassed DCM. NEt $3(0.031 \mathrm{~mL}, 0.22 \mathrm{~mol})$ was added followed by a solution of $\mathrm{Pd}_{2}(\mathrm{dba})_{3} \cdot \mathrm{CHCl}_{3}(4.1 \mathrm{mg}, 0.004 \mathrm{mmol})$ and $(R, R)-\mathbf{L}-1(8.3 \mathrm{mg}, 0.012 \mathrm{mmol})$ in $0.5 \mathrm{~mL}$ degassed DCM. The resulting red solution was stirred for $2 \mathrm{~h}$ at $0{ }^{\circ} \mathrm{C}$ at which point the mixture was concentrated in vacuo. The resulting oily residue was purified via flash chromatography (silica, $0-50 \%$ ether/petroleum ether, gradient) to yield $31 \mathrm{mg}(60 \%)$ of 45 as an colorless oil. $[\alpha]_{\mathrm{D}}-42.23\left(\mathrm{c}=1.40, \mathrm{CH}_{2} \mathrm{Cl}_{2}\right.$ ). IR (film from $\left.\mathrm{CDCl}_{3}\right)$ : 2956, 1741, 1624, 1249, 1177, 1146, 869, $840 \mathrm{~cm}^{-1} .{ }^{1} \mathrm{H}$ NMR $\left(300 \mathrm{MHz}, \mathrm{CDCl}_{3}\right) \delta 5.77$ (ddd, J $=5.4,10.5,15.9 \mathrm{~Hz}, 1 \mathrm{H}), 5.24(\mathrm{~s}, 1 \mathrm{H}), 5.12(\mathrm{~m}, 2 \mathrm{H}), 4.28(\mathrm{~m}, 1 \mathrm{H}), 4.15(\mathrm{~m}, 1 \mathrm{H}), 3.94$ (m, $2 \mathrm{H}), 2.37(\mathrm{~m}, 2 \mathrm{H}), 2.31$ (t, J = 7.5 Hz, $2 \mathrm{H}), 2.14(\mathrm{~m}, 2 \mathrm{H}), 1.55$ (qt, J = 7.5, 7.5 Hz, $2 \mathrm{H}), 0.86(\mathrm{t}, \mathrm{J}=7.5 \mathrm{~Hz}, 3 \mathrm{H}), 0.01(\mathrm{~s}, 9 \mathrm{H}) .{ }^{13} \mathrm{C} \mathrm{NMR}\left(75 \mathrm{MHz}, \mathrm{CDCl}_{3}\right) \delta 173.44$, $149.47,137.44,125.88,116.95,73.65,70.12,64.83,43.31,36.03,35.32,18.38,13.62$, 0.18 (3 C). Anal calcd for $\mathrm{C}_{16} \mathrm{H}_{28} \mathrm{O}_{3} \mathrm{Si}: \mathrm{C}, 64.82 \% ; \mathrm{H}, 9.52 \%$. Found: $\mathrm{C}, 64.64 \% ; \mathrm{H}$, $9.50 \%$.

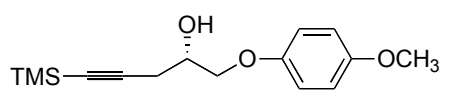

Compound 46. Step 1: The resolution of racemic epoxide was performed in analogy to a literature procedure. ${ }^{9} \mathrm{AcOH}(0.02 \mathrm{~g}, 0.345 \mathrm{mmol})$ was added to a solution of $(R, R)$ Salen $(\mathrm{Co})^{\mathrm{II}}(0.10 \mathrm{~g}, 0.17 \mathrm{mmol})$ in $1.5 \mathrm{~mL}$ toluene. The solution was stirred at room temperature, open to the air for $1 \mathrm{~h}$. The resulting solution was concentrated in vacuo and dried under high vacuum. The resulting residue was diluted with $11 \mathrm{~mL}$ ether. ( $\mathrm{rac}$ )-2-(4Methoxy-phenoxymethyl)-oxirane $(3.0 \mathrm{~g}, 16.7 \mathrm{mmol})$ was added followed by the addition of water $(0.16 \mathrm{~g}, 9.2 \mathrm{mmol})$. The reaction was stirred at room temperature for 5 days at which time it was concentrated in vacuo and purified via flash chromatography (silica, ether/petroleum ether, gradient) to yield $1.3 \mathrm{~g} \mathrm{(86 \% )} \mathrm{of} \mathrm{(S)-2-(4-methoxy-}$ phenoxymethyl)-oxirane as a colorless oil. Step $2: n-\mathrm{BuLi}(10.6 \mathrm{~mL}$ of $1.6 \mathrm{M}$ in hexanes) 
was added to a cooled $\left(-78^{\circ} \mathrm{C}\right)$ solution of trimethylsilyl acetylene $(1.74 \mathrm{~g}, 17.7 \mathrm{mmol})$ in $35 \mathrm{~mL}$ THF. The solution was stirred for 20 min while warming slowly to $0{ }^{\circ} \mathrm{C}$ at which time it was cooled to $-78^{\circ} \mathrm{C}$. $(S)$-2-(4-Methoxy-phenoxymethyl)-oxirane $(1.3 \mathrm{~g}, 7.21$ $\mathrm{mmol})$ was added followed by the addition of $\mathrm{BF}_{3} \cdot \mathrm{OEt}_{2}(2.0 \mathrm{~g}, 14.2 \mathrm{mmol})$. The reaction was stirred at $-78{ }^{\circ} \mathrm{C}$ for $3 \mathrm{~h}$ at which time it was quenched with saturated aq. ammonium chloride and warmed to room temperature. The aqueous layer was extracted 3 times with ether. The combined organic layers were washed with brine, dried over magnesium sulfate, filtered, and concentrated in vacuo. The resulting residue was purified via flash chromatography (silica, ether/petroleum ether, gradient) to yield $1.47 \mathrm{~g}$ (73\%) of 46 as a colorless oil. $\mathrm{R}_{\mathrm{f}}=0.36$ in $50 \%$ ether/petroleum ether. The enantiomeric excess was determined to be 99\% via HPLC analysis. (Chiralcel OD column, 90:10 heptane:iPrOH, flow rate $=1.0 \mathrm{~mL} / \mathrm{min}, 254 \mathrm{~nm}, \mathrm{t}_{\mathrm{r}}: 7.83$ (minor), 11.78 (major)). $[\alpha]_{\mathrm{D}}+18.48(\mathrm{c}=2.08$, $\mathrm{CH}_{2} \mathrm{Cl}_{2}$ ). IR (film from $\mathrm{CDCl}_{3}$ ): 3448, 2957, 2176, 1509, 1249, 1043, 843, $760 \mathrm{~cm}^{-1} .{ }^{1} \mathrm{H}$ NMR (300 MHz, $\left.\mathrm{CDCl}_{3}\right) \delta 6.70(\mathrm{~m}, 4 \mathrm{H}), 3.96(\mathrm{~m}, 1 \mathrm{H}), 3.89$ (dd, J = 9.6, $\left.3.9 \mathrm{~Hz}, 1 \mathrm{H}\right)$, 3.79 (dd, J = 9.3, $6.6 \mathrm{~Hz}, 1 \mathrm{H}), 3.61$ (s, $3 \mathrm{H}), 2.44$ (d, J = 6.3 Hz, $2 \mathrm{H}), 0.01$ (s, $9 \mathrm{H})$. Hydroxyl proton was not observed. ${ }^{13} \mathrm{C} \mathrm{NMR}\left(75 \mathrm{MHz}, \mathrm{CDCl}_{3}\right) \delta 154.05,152.53,115.49$ (2 C), 114.59 (2 C), 102.06, 87.66, 71.16, 68.44, 55.63, 24.92, -0.05 (3 C). Anal calcd for $\mathrm{C}_{15} \mathrm{H}_{22} \mathrm{O}_{3} \mathrm{Si}$ : C, 64.71\%; H, 7.96\%. Found: C, 64.89\%; H, 7.70\%.

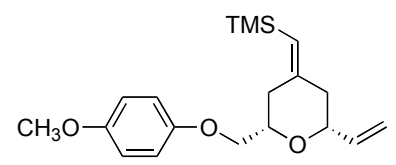

Compound 47. For Condition $\mathrm{D}$ : $\left[\mathrm{CpRu}\left(\mathrm{CH}_{3} \mathrm{CN}\right)_{3}\right] \mathrm{PF}_{6}(8.7 \mathrm{mg}, 0.02 \mathrm{mmol})$ was added to a flame-dried test tube under argon. A solution of $46(56 \mathrm{mg}, 0.20 \mathrm{mmol})$ and $15(0.22$ $\mathrm{g}, 1.1 \mathrm{mmol})$ in degassed acetone $(1.0 \mathrm{~mL})$ was added to the catalyst via cannula. The reaction was stirred at room temperature under argon for $6 \mathrm{~h}$ at which time it was directly concentrated in vacuo. The resulting oily residue was purged with argon and dissolved in $2.0 \mathrm{~mL}$ degassed $\mathrm{DCM}$. $\mathrm{NEt}_{3}(0.031 \mathrm{~mL}, 0.22 \mathrm{mmol})$ was added followed by a solution of $\mathrm{Pd}_{2}(\mathrm{dba})_{3} \cdot \mathrm{CHCl}_{3}(4.1 \mathrm{mg}, 0.004 \mathrm{mmol})$ and $(R, R)-\mathbf{L}-\mathbf{1}(8.3 \mathrm{mg}, 0.012 \mathrm{mmol})$ in $0.5 \mathrm{~mL}$ degassed DCM. The resulting red solution was stirred for $2 \mathrm{~h}$ at $0{ }^{\circ} \mathrm{C}$ at which point the mixture was concentrated in vacuo. The resulting oily residue was purified via flash chromatography (silica, $0-50 \%$ ether/petroleum ether, gradient) to yield $39 \mathrm{mg}$ $(58 \%)$ of 47 as an colorless oil. $[\alpha]_{\mathrm{D}}+5.61\left(\mathrm{c}=1.03, \mathrm{CH}_{2} \mathrm{Cl}_{2}\right)$. IR (film from $\left.\mathrm{CD}_{3} \mathrm{CN}\right)$ : 2952, 1509, 1233, 1046, $841 \mathrm{~cm}^{-1} .{ }^{1} \mathrm{H} \operatorname{NMR}\left(500 \mathrm{MHz}, \mathrm{CDCl}_{3}\right) \delta 6.89(\mathrm{~d}, \mathrm{~J}=9.5 \mathrm{~Hz}, 2$ H), 6.85 (d, J = 9.5 Hz, 2 H), $5.93(\mathrm{ddd}, \mathrm{J}=6.0,10.5,17.5 \mathrm{~Hz}, 1 \mathrm{H}), 5.36(\mathrm{~s}, 1 \mathrm{H}), 5.31$ $(\mathrm{dt}, \mathrm{J}=17.5,1.5 \mathrm{~Hz}, 1 \mathrm{H}), 5.17(\mathrm{dt}, \mathrm{J}=10.5,1.5 \mathrm{~Hz}, 1 \mathrm{H}), 4.11(\mathrm{dd}, \mathrm{J}=10.0,5.5 \mathrm{~Hz}, 1$ H), $3.96(\mathrm{~m}, 1 \mathrm{H}), 3.94$ (dd, J = 10.0, $5.5 \mathrm{~Hz}, 1 \mathrm{H}), 3.79$ (s, $3 \mathrm{H}), 2.73$ (ddt, J = 10.5, 2.0, $6.0 \mathrm{~Hz}, 1 \mathrm{H}), 2.65(\mathrm{~d}, \mathrm{~J}=12.5 \mathrm{~Hz}, 1 \mathrm{H}), 2.27(\mathrm{~m}, 2 \mathrm{H}), 2.10(\mathrm{t}, \mathrm{J}=12.5 \mathrm{~Hz}, 1 \mathrm{H}),-0.15$ (s, $9 \mathrm{H}) .{ }^{13} \mathrm{C}$ NMR $\left(75 \mathrm{MHz}, \mathrm{CDCl}_{3}\right) \delta 153.87,152.97,152.24,138.37,124.07,115.57$ (2 C), 114.54 (2 C), 79.54, 76.47 (2 C), 71.50, 55.69, 45.69, 36.74, 0.24 (3 C). Anal calcd for $\mathrm{C}_{19} \mathrm{H}_{28} \mathrm{O}_{3} \mathrm{Si}$ : C, $68.63 \%$; H, 8.49\%. Found: C, 68.86\%; H, 8.29\%. 


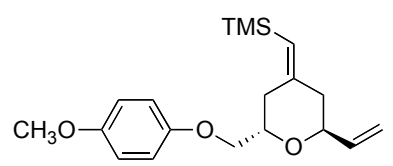

Compound 48. For Condition D: $\left[\mathrm{CpRu}\left(\mathrm{CH}_{3} \mathrm{CN}\right)_{3}\right] \mathrm{PF}_{6}(8.7 \mathrm{mg}, 0.02 \mathrm{mmol})$ was added to a flame-dried test tube under argon. A solution of $46(56 \mathrm{mg}, 0.20 \mathrm{mmol})$ and $15(0.22$ $\mathrm{g}, 1.1 \mathrm{mmol})$ in degassed acetone $(1.0 \mathrm{~mL})$ was added to the catalyst via cannula. The reaction was stirred at room temperature under argon for $6 \mathrm{~h}$ at which time it was directly concentrated in vacuo. The resulting oily residue was purged with argon and dissolved in $2.0 \mathrm{~mL}$ degassed $\mathrm{DCM}$. $\mathrm{NEt}_{3}(0.031 \mathrm{~mL}, 0.22 \mathrm{mmol})$ was added followed by a solution of $\mathrm{Pd}_{2}(\mathrm{dba})_{3} \cdot \mathrm{CHCl}_{3}(4.1 \mathrm{mg}, 0.004 \mathrm{mmol})$ and $(S, S)-\mathbf{L}-\mathbf{1}(8.3 \mathrm{mg}, 0.012 \mathrm{mmol})$ in $0.5 \mathrm{~mL}$ degassed DCM. The resulting red solution was stirred for $2 \mathrm{~h}$ at $0{ }^{\circ} \mathrm{C}$ at which point the mixture was concentrated in vacuo. The resulting oily residue was purified via flash chromatography (silica, $0-50 \%$ ether/petroleum ether, gradient) to yield $39 \mathrm{mg}$ $(58 \%)$ of 48 as an colorless oil. $[\alpha]_{\mathrm{D}}+41.72\left(\mathrm{c}=1.10, \mathrm{CH}_{2} \mathrm{Cl}_{2}\right)$ for $88 \%$ diastereomeric excess. IR (film from $\mathrm{CDCl}_{3}$ ): 2951, 1509, 1232, 1046, 872, $839 \mathrm{~cm}^{-1} .{ }^{1} \mathrm{H}$ NMR $(500$ $\left.\mathrm{MHz}, \mathrm{CDCl}_{3}\right) \delta 6.88(\mathrm{~d}, \mathrm{~J}=9.5 \mathrm{~Hz}, 2 \mathrm{H}), 6.84(\mathrm{~d}, \mathrm{~J}=9.0 \mathrm{~Hz}, 2 \mathrm{H}), 5.94(\mathrm{ddd}, \mathrm{J}=5.5$, $10.5,17.5 \mathrm{~Hz}, 1 \mathrm{H}), 5.37$ (s, $1 \mathrm{H}), 5.30$ (dt, J = 17.5, $1.5 \mathrm{~Hz}, 1 \mathrm{H}), 5.23$ (dt, J = 10.5, 1.5 $\mathrm{Hz}, 1 \mathrm{H}), 4.43(\mathrm{~m}, 1 \mathrm{H}), 4.21(\mathrm{~m}, 1 \mathrm{H}), 4.04(\mathrm{dd}, \mathrm{J}=9.5,6.0 \mathrm{~Hz}, 1 \mathrm{H}), 3.94(\mathrm{dd}, \mathrm{J}=9.5$, $6.0 \mathrm{~Hz}, 1 \mathrm{H}), 3.79(\mathrm{~s}, 3 \mathrm{H}), 2.56(\mathrm{~m}, 1 \mathrm{H}), 2.54(\mathrm{~m}, 1 \mathrm{H}), 2.38(\mathrm{dd}, \mathrm{J}=13.5,7.0 \mathrm{~Hz}, 1 \mathrm{H})$, 2.31 (ddd, J $=13.5,6.0,1.5 \mathrm{~Hz}, 1 \mathrm{H}), 0.12(\mathrm{~s}, 9 \mathrm{H}) .{ }^{13} \mathrm{C} \mathrm{NMR}\left(75 \mathrm{MHz}, \mathrm{CDCl}_{3}\right) \delta 153.96$, 152.87, 149.88, 137.55, 125.77, 116.97, 115.48 (2 C), 114.51 (2 C), 74.06, 70.71, 69.62, 55.66, 43.48, 35.58, $0.19(3 \mathrm{C})$. Anal calcd for $\mathrm{C}_{19} \mathrm{H}_{28} \mathrm{O}_{3} \mathrm{Si}: \mathrm{C}, 68.63 \%$; H, 8.49\%. Found: C, $68.52 \% ; \mathrm{H}, 8.35 \%$.

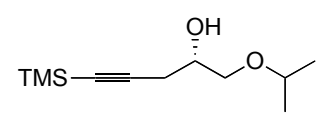

Compound 49. Step 1: The resolution of racemic epoxide was performed in analogy to a literature procedure. ${ }^{9} \mathrm{AcOH}(0.02 \mathrm{~g}, 0.35 \mathrm{mmol})$ was added to a solution of $(R, R)$ Salen $(\mathrm{Co})^{\mathrm{II}}(0.10 \mathrm{~g}, 0.17 \mathrm{mmol})$ in $1.5 \mathrm{~mL}$ toluene. The solution was stirred at room temperature, open to the air for $1 \mathrm{~h}$. The resulting solution was concentrated in vacuo and dried under high vacuum. The resulting residue was diluted with $11 \mathrm{~mL}$ ether. (rac)-2Isopropoxymethyl-oxirane $(1.9 \mathrm{~g}, 16.7 \mathrm{mmol})$ was added followed by the addition of water $(0.165 \mathrm{~g}, 9.2 \mathrm{mmol})$. The reaction was stirred at room temperature for 3 days at which time it was concentrated in vacuo and purified via kugelrohr distillation at atmospheric pressure (boiling point: $132-133^{\circ} \mathrm{C}$ ) to yield $0.91 \mathrm{~g}(93 \%)$ of $(S)-2-$ isopropoxymethyl-oxirane as a colorless oil. Step 2: $n$-BuLi $(10.6 \mathrm{~mL}$ of $1.4 \mathrm{M}$ in hexanes) was added to a cooled $\left(-78^{\circ} \mathrm{C}\right)$ solution of trimethylsilyl acetylene $(1.5 \mathrm{~g}, 15.5$ $\mathrm{mmol}$ ) in $35 \mathrm{~mL}$ THF. The solution was stirred for $20 \mathrm{~min}$ while warming slowly to $0{ }^{\circ} \mathrm{C}$ at which time it was cooled to $-78^{\circ} \mathrm{C}$. $(S)$-2-Isopropoxymethyl-oxirane $(0.72 \mathrm{~g}, 6.2$ $\mathrm{mmol})$ was added followed by the addition of $\mathrm{BF}_{3} \cdot \mathrm{OEt}_{2}(1.76 \mathrm{~g}, 12.4 \mathrm{mmol})$. The reaction was stirred at $-78{ }^{\circ} \mathrm{C}$ for $3 \mathrm{~h}$ at which time it was quenched with saturated aq. ammonium chloride and warmed to room temperature. The aqueous layer was extracted three times with ether. The combined organic layers were washed with brine, dried over magnesium sulfate, filtered, and concentrated in vacuo. The resulting residue was purified via flash chromatography (silica, ether/petroleum ether, gradient) to yield $0.80 \mathrm{~g}$ 
$(60 \%)$ of 49 as a colorless oil. The enantiomeric excess was determined to be $99 \%$ via HPLC analysis of a derivative (82). $[\alpha]_{\mathrm{D}}+18.51\left(\mathrm{c}=2.38, \mathrm{CH}_{2} \mathrm{Cl}_{2}\right)$. IR (neat): 3443 , 2971, 2177, 1391, 1370, 1250, 1130, 1094, 843, $760 \mathrm{~cm}^{-1} .{ }^{1} \mathrm{H}$ NMR $\left(300 \mathrm{MHz}, \mathrm{CDCl}_{3}\right) \delta$ 3.70 (m, $1 \mathrm{H}), 3.45$ (p, J = 6.3 Hz, $1 \mathrm{H}), 3.39$ (dd, J = 9.3, $3.9 \mathrm{~Hz}, 1 \mathrm{H}), 3.24$ (dd, J = 9.3, $6.3 \mathrm{~Hz}, 1 \mathrm{H}), 2.30(\mathrm{~m}, 3 \mathrm{H}), 1.00(\mathrm{~d}, \mathrm{~J}=6.3 \mathrm{~Hz}, 6 \mathrm{H}),-0.02(\mathrm{~s}, 9 \mathrm{H}) .{ }^{13} \mathrm{C}$ NMR $(125$ $\left.\mathrm{MHz}, \mathrm{CDCl}_{3}\right) \delta 102.72,87.08,72.16,70.53,68.93,24.92,22.06,21.98,0.02$ (3 C). Anal calcd for $\mathrm{C}_{11} \mathrm{H}_{22} \mathrm{O}_{2} \mathrm{Si}$ : C, $61.63 \%$; H, 10.34\%. Found: C, 61.30\%; H, 10.25\%.

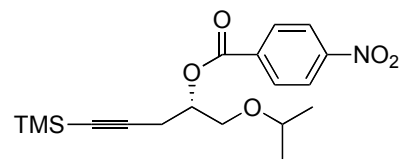

Compound 82. A solution of DCC (66 mg, $0.33 \mathrm{mmol})$ and DMAP (23 mg, $0.19 \mathrm{mmol})$ in $0.2 \mathrm{~mL}$ DCM was added dropwsie to a cooled $\left(0{ }^{\circ} \mathrm{C}\right)$ solution of $49(42 \mathrm{mg}, 0.20$ $\mathrm{mmol}$ ) and 4-nitrobenzoic acid (55 $\mathrm{mg}, 0.33 \mathrm{mmol})$ in $0.4 \mathrm{~mL}$ DCM. The resulting white slurry was stirred at room temperature overnight. The mixture was then eluted through a plug of celite with DCM. The filtrate was washed two times with $1 \mathrm{M} \mathrm{HCl}$ and once with brine, dried over magnesium sulfate, and filtered. The filtrate was concentrated in vacuo and purified via flash chromatography (silica, ether/petroleum ether, gradient) to yield 70 $\mathrm{mg}(96 \%)$ of $\mathbf{8 2}$ as a colorless oil. The enantiomeric excess was determined to be $99 \%$ via HPLC analysis. (Chiralcel AD column, 99.9:0.1 heptane:iPrOH, flow rate $=1.0 \mathrm{~mL} / \mathrm{min}$, $254 \mathrm{~nm}, \mathrm{t}_{\mathrm{r}}: 16.00$ (minor), 18.83 (major)). $[\alpha]_{\mathrm{D}}-4.63\left(\mathrm{c}=1.25, \mathrm{C}_{6} \mathrm{H}_{6}\right)$. IR (film from $\left.\mathrm{CDCl}_{3}\right): 2972,2180,1729,1531,1349,1273,1119,1104,843,720 \mathrm{~cm}^{-1} .{ }^{1} \mathrm{H}$ NMR $(300$ $\left.\mathrm{MHz}, \mathrm{CDCl}_{3}\right) \delta 8.28(\mathrm{~d}, \mathrm{~J}=9.0 \mathrm{~Hz}, 2 \mathrm{H}), 8.07(\mathrm{~d}, \mathrm{~J}=9.0 \mathrm{~Hz}, 2 \mathrm{H}), 5.15(\mathrm{~m}, 1 \mathrm{H}), 3.57$ $(\mathrm{d}, \mathrm{J}=5.4 \mathrm{~Hz}, 2 \mathrm{H}), 3.48(\mathrm{p}, \mathrm{J}=6.0 \mathrm{~Hz}, 1 \mathrm{H}), 2.58(\mathrm{dd}, \mathrm{J}=6.0,2.4 \mathrm{~Hz}, 2 \mathrm{H}), 1.01(\mathrm{~d}, \mathrm{~J}=$ $6.0 \mathrm{~Hz}, 6 \mathrm{H}),-0.05(\mathrm{~s}, 9 \mathrm{H}) .{ }^{13} \mathrm{C}$ NMR $\left(75 \mathrm{MHz}, \mathrm{CDCl}_{3}\right) \delta 164.00,150.51,135.51$, 130.82 (2 C), 123.45 (2 C), 101.40, 87.39, 72.45, 72.32, 67.50, 22.31, 22.00, 21.89, -0.13 (3 C). Anal calcd for $\mathrm{C}_{18} \mathrm{H}_{25} \mathrm{NO}_{5} \mathrm{Si}: \mathrm{C}, 59.48 \%$; H, 6.93\%. Found: C, 59.60\%; H, 6.79\%.<smiles>C=CC1CC(=CC)COC1COC(C)C</smiles>

Compound 50. For Condition $\mathrm{D}:\left[\mathrm{CpRu}\left(\mathrm{CH}_{3} \mathrm{CN}\right)_{3}\right] \mathrm{PF}_{6}(8.7 \mathrm{mg}, 0.02 \mathrm{mmol})$ was added to a flame-dried test tube under argon. A solution of $49(4.3 \mathrm{mg}, 0.20 \mathrm{mmol})$ and $15(0.22$ $\mathrm{g}, 1.1 \mathrm{mmol})$ in degassed acetone $(1.0 \mathrm{~mL})$ was added to the catalyst via cannula. The reaction was stirred at room temperature under argon for $6 \mathrm{~h}$ at which time it was directly concentrated in vacuo. The resulting oily residue was purged with argon and dissolved in $2.0 \mathrm{~mL}$ degassed $\mathrm{DCM}$. $\mathrm{NEt}_{3}(0.031 \mathrm{~mL}, 0.22 \mathrm{mmol})$ was added followed by a solution of $\mathrm{Pd}_{2}(\mathrm{dba})_{3} \cdot \mathrm{CHCl}_{3}(4.1 \mathrm{mg}, 0.004 \mathrm{mmol})$ and $(R, R)-\mathbf{L}-\mathbf{1}(8.3 \mathrm{mg}, 0.012 \mathrm{mmol})$ in $0.5 \mathrm{~mL}$ degassed DCM. The resulting red solution was stirred for $2 \mathrm{~h}$ at $0{ }^{\circ} \mathrm{C}$ at which point the mixture was concentrated in vacuo. The resulting oily residue was purified via flash chromatography (silica, $0-50 \%$ ether/petroleum ether, gradient) to yield $31 \mathrm{mg}$ $(58 \%)$ of 50 as a colorless oil. $[\alpha]_{\mathrm{D}}-20.78\left(\mathrm{c}=2.06, \mathrm{CDCl}_{3}\right)$. IR (film from $\left.\mathrm{CDCl}_{3}\right)$ : 2972, 1624, 1249, 1140, 1090, $879 \mathrm{~cm}^{-1} .{ }^{1} \mathrm{H}$ NMR $\left(300 \mathrm{MHz}, \mathrm{CDCl}_{3}\right) \delta 5.73(\mathrm{ddd}, \mathrm{J}=$ 
5.7, 10.5, 17.1 Hz, $1 \mathrm{H}), 5.12(\mathrm{~s}, 1 \mathrm{H}), 5.00(\mathrm{~m}, 2 \mathrm{H}), 3.70(\mathrm{~m}, 1 \mathrm{H}), 3.45(\mathrm{~m}, 2 \mathrm{H}), 3.30$ (m, $2 \mathrm{H}), 2.37(\mathrm{~d}, \mathrm{~J}=13.2 \mathrm{~Hz}, 1 \mathrm{H}), 2.05(\mathrm{~m}, 2 \mathrm{H}), 1.77(\mathrm{t}, \mathrm{J}=12.0 \mathrm{~Hz}, 1 \mathrm{H}), 1.01(\mathrm{~d}, \mathrm{~J}=$ $6.0 \mathrm{~Hz}, 6 \mathrm{H}),-0.05(\mathrm{~s}, 9 \mathrm{H}) .{ }^{13} \mathrm{C}$ NMR $\left(75 \mathrm{MHz}, \mathrm{CDCl}_{3}\right) \delta$ 152.87, 138.63, 123.53, 115.19, 79.33, 77.49, 72.18, 71.34, 45.29, 36.97, 22.45, 22.00, 0.24 (3 C). HRMS Calcd for $\mathrm{C}_{15} \mathrm{H}_{28} \mathrm{O}_{2} \mathrm{Si}$ : 268.1859. Found: 268.1854 .

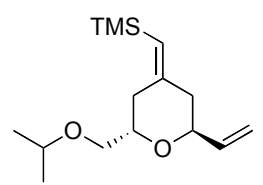

Compound 51. For Condition D: $\left[\mathrm{CpRu}\left(\mathrm{CH}_{3} \mathrm{CN}\right)_{3}\right] \mathrm{PF}_{6}(8.7 \mathrm{mg}, 0.02 \mathrm{mmol})$ was added to a flame-dried test tube under argon. A solution of $49(4.3 \mathrm{mg}, 0.20 \mathrm{mmol})$ and 15 $(0.22 \mathrm{~g}, 1.1 \mathrm{mmol})$ in degassed acetone $(1.0 \mathrm{~mL})$ was added to the catalyst via cannula. The reaction was stirred at room temperature under argon for $6 \mathrm{~h}$ at which time it was directly concentrated in vacuo. The resulting oily residue was purged with argon and dissolved in $2.0 \mathrm{~mL}$ degassed $\mathrm{DCM}$. $\mathrm{NEt}_{3}(0.031 \mathrm{~mL}, 0.22 \mathrm{~mol})$ was added followed by a solution of $\mathrm{Pd}_{2}(\mathrm{dba})_{3} \cdot \mathrm{CHCl}_{3}(4.1 \mathrm{mg}, 0.004 \mathrm{mmol})$ and $(S, S)-\mathbf{L}-1$ ( $\left.8.3 \mathrm{mg}, 0.012 \mathrm{mmol}\right)$ in $0.5 \mathrm{~mL}$ degassed DCM. The resulting red solution was stirred for $2 \mathrm{~h}$ at $0{ }^{\circ} \mathrm{C}$ at which point the mixture was concentrated in vacuo. The resulting oily residue was purified via flash chromatography (silica, $0-50 \%$ ether/petroleum ether, gradient) to yield $31 \mathrm{mg}$ $(58 \%)$ of 51 as an colorless oil. $[\alpha]_{\mathrm{D}}+23.25\left(\mathrm{c}=2.03, \mathrm{CH}_{2} \mathrm{Cl}_{2}\right)$. IR (film from $\left.\mathrm{CDCl}_{3}\right)$ : 2972, 2897, 1624, 1249, 1130, 1086, 871, $841 \mathrm{~cm}^{-1} .{ }^{1} \mathrm{H}$ NMR (500 MHz, $\left.\mathrm{CDCl}_{3}\right) \delta 5.92$ (ddd, J = 6.0, 10.5, 17.5 Hz, 1 H), $5.32(\mathrm{~s}, 1 \mathrm{H}), 5.27$ (dt, J = 17.5, $1.5 \mathrm{~Hz}, 1 \mathrm{H}), 5.20$ (dt, $\mathrm{J}=10.5,1.5 \mathrm{~Hz}, 1 \mathrm{H}), 4.36$ (q, J = 5.5 Hz, $1 \mathrm{H}), 3.96$ (ddd, J = 6.0, 10.5, $11.5 \mathrm{~Hz}, 1 \mathrm{H}$ ), $3.62(\mathrm{p}, \mathrm{J}=6.0 \mathrm{~Hz}, 1 \mathrm{H}), 3.53(\mathrm{dd}, \mathrm{J}=6.0,9.5 \mathrm{~Hz}, 1 \mathrm{H}), 3.43(\mathrm{dd}, \mathrm{J}=6.0,9.5 \mathrm{~Hz}, 1 \mathrm{H})$, $2.51(\mathrm{dd}, \mathrm{J}=13.5,4.5 \mathrm{~Hz}, 2 \mathrm{H}), 2.46(\mathrm{dd}, \mathrm{J}=13.5,4.0 \mathrm{~Hz}, 2 \mathrm{H}), 1.19(\mathrm{~d}, \mathrm{~J}=6.0 \mathrm{~Hz}, 6$ $\mathrm{H}), 0.13(\mathrm{~s}, 9 \mathrm{H}) .{ }^{13} \mathrm{C}$ NMR $\left(125 \mathrm{MHz}, \mathrm{CDCl}_{3}\right) \delta 150.54,137.79,125.18,116.72,73.87$, 72.02, 71.51, 69.57, 43.45, 35.77, 22.13, 21.95, 0.22 (3 C). Anal calcd for $\mathrm{C}_{15} \mathrm{H}_{28} \mathrm{O}_{2} \mathrm{Si}: \mathrm{C}$, $67.11 \%$; H, 10.51\%. Found: C, 67.38\%; H, 10.70\%.

$\mathrm{TMS}=\mathrm{NHTS}$

Compound 57. Diisopropylazodicarboxylate $(2.4 \mathrm{~g}, 11.9 \mathrm{mmol})$ was added to a cooled $\left(0{ }^{\circ} \mathrm{C}\right)$ solution of 2-propyne-1-ol $(0.56 \mathrm{~g}, 10.0 \mathrm{mmol})$, NHBocTos $(3.26 \mathrm{~g}, 12.0 \mathrm{mmol})$ and triphenylphosphine $(3.15 \mathrm{~g}, 12.0 \mathrm{mmol})$ in THF $(35 \mathrm{~mL})$. The reaction was warmed slowly to room temperature overnight at which point it was concentrated in vacuo. The resulting oily residue was purified directly by flash chromatography (silica, $15-20 \%$ ether/petroleum ether, gradient) to yield $2.7 \mathrm{~g}(88 \%)$ of boc-tosyl-protected alkynylamine. This product $(2.65 \mathrm{~g}, 8.6 \mathrm{mmol})$ was dissolved in methylene chloride (25 $\mathrm{mL})$. Triflouroacetic acid $(4.9 \mathrm{~g}, 43 \mathrm{mmol})$ was added and the reaction was stirred at room temperature for $24 \mathrm{~h}$. The resulting mixture was concentrated in vacuo and purified directly by flash chromatography (silica, 20-60\% ether/pet ether, gradient) to yield 1.73 $\mathrm{g}(96 \%)$ of tosyl-protected alkynylamine. This product $(1.66 \mathrm{~g}, 7.91 \mathrm{mmol})$ was dissolved in THF $(16 \mathrm{~mL})$ and cooled to $-78{ }^{\circ} \mathrm{C}$. $n$-Butyllithium $(9 \mathrm{~mL}$ of $1.6 \mathrm{M}$ in hexanes $)$ was added dropwise. The solution was warmed to $0{ }^{\circ} \mathrm{C}$ and stirred for $45 \mathrm{~min}$. Trimethylsilyl chloride $(1.71 \mathrm{~g}, 15.76 \mathrm{mmol})$ was added and the reaction was warmed slowly to room 
temperature until complete conversion was obtained. The resulting solution was quenched with water. The aqueous layer was extracted three times with ether. The combined organic layers were washed with water and brine, dried over magnesium sulfate, and concentrated in vacuo. The resulting oily residue was purified by flash chromatography (silica, 10-30 \% ether/petroleum ether, gradient) to yield $1.58 \mathrm{~g}(71 \%)$ of 57 as a white solid. $m p=113-114^{\circ} \mathrm{C} . \mathrm{R}_{\mathrm{f}}=0.71$ in $50 \%$ ether/pet ether. IR (film): $3270,2965,1432,1329,1250,1166,1094,1063,995,848 \mathrm{~cm}^{-1}$. ${ }^{1} \mathrm{H}$ NMR $(300 \mathrm{MHz}$, $\left.\mathrm{CDCl}_{3}\right) \delta 7.77(\mathrm{~d}, \mathrm{~J}=8.4 \mathrm{~Hz}, 2 \mathrm{H}), 7.30(\mathrm{~d}, \mathrm{~J}=7.8 \mathrm{~Hz}, 2 \mathrm{H}), 4.67(\mathrm{~m}, 1 \mathrm{H}) 3.85(\mathrm{~d}, \mathrm{~J}=6$ $\mathrm{Hz}, 2 \mathrm{H}), 2.42$ (s, $3 \mathrm{H}), 0.02$ (s, $9 \mathrm{H}) .{ }^{13} \mathrm{C} \mathrm{NMR}\left(75 \mathrm{MHz}, \mathrm{CDCl}_{3}\right) \delta$ 143.66, 136.69, 129.66 (2 C), 127.41 (2 C), 99.34, 89.81, 33.82, 21.54, -0.48 (3 C). Anal calcd for $\mathrm{C}_{13} \mathrm{H}_{19} \mathrm{NO}_{2} \mathrm{SSi}$ : C, $55.48 \%$; H, 6.80\%; N, 4.98\%. Found: C, 55.66\%; H, 6.91\%; N, $5.01 \%$.

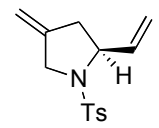

Compound 59. TFA $(0.47 \mathrm{~mL}, 6.13 \mathrm{mmol})$ was added to a solution of $\mathbf{5 8}(0.51 \mathrm{~g}, 1.53$ $\mathrm{mmol})$ in toluene $(21 \mathrm{~mL})$. The reaction was stirred at room temperature for $27 \mathrm{~h}$ at which time it was concentrated in vacuo. The resulting oily residue was purified via flash chromatography (silica, ether/petroleum ether, gradient) to yield $0.34 \mathrm{~g} \mathrm{(83 \% )} \mathrm{of} \mathbf{5 9}$ as a light yellow oil. $[\alpha]_{\mathrm{D}}+41.93\left(\mathrm{c}=1.5, \mathrm{CH}_{2} \mathrm{Cl}_{2}\right)$, for $94 \%$ ee. $\mathrm{R}_{\mathrm{f}}=0.56$ in $30 \%$ ether/petroleum ether; cerium molybdate stain. IR (neat): 2923, 1672, 1436, 1347, 1161, 1095, 894, 816, $668 \mathrm{~cm}^{-1} .{ }^{1} \mathrm{H}$ NMR $\left(400 \mathrm{MHz} \mathrm{CDCl}_{3}\right) \delta 7.69(\mathrm{~d}, \mathrm{~J}=8.4 \mathrm{~Hz}, 2 \mathrm{H}), 7.28$ (d, J = 8.4 Hz, $2 \mathrm{H}), 5.74$ (ddd, J = 6.4, 10.4, $17.2 \mathrm{~Hz}, 1 \mathrm{H}), 5.21(\mathrm{~d}, \mathrm{~J}=17.2 \mathrm{~Hz}, 1 \mathrm{H})$, $5.09(\mathrm{~d}, \mathrm{~J}=10.4 \mathrm{~Hz}, 1 \mathrm{H}), 4.90(\mathrm{~m}, 2 \mathrm{H}), 4.18(\mathrm{~m}, 1 \mathrm{H}), 3.96-3.86(\mathrm{~m}, 2 \mathrm{H}), 2.44(\mathrm{~m}, 1$ $\mathrm{H}), 2.41(\mathrm{~s}, 3 \mathrm{H}), 2.26(\mathrm{~m}, 1 \mathrm{H}) .{ }^{13} \mathrm{C}$ NMR $\left(100 \mathrm{MHz}, \mathrm{CDCl}_{3}\right) \delta$ 143.46, 142.95, 137.49, $134.83,129.59$ (2 C), 127.61 (2 C), 115.74, 107.90, 62.17, 52.02, 38.94, 21.52. Anal calcd for $\mathrm{C}_{14} \mathrm{H}_{17} \mathrm{NO}_{2} \mathrm{~S}: \mathrm{C}, 63.85 \%$; H, 6.51\%; N, 5.32\%. Found: C, 64.01\%; H, 6.72\%; N, $5.18 \%$.

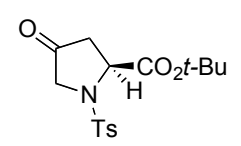

Compound 60. The oxidation procedure was performed in analogy to a literature procedure. ${ }^{11}$ Vinyl pyrrolidine $\mathbf{5 9}(60 \mathrm{mg}, 0.22 \mathrm{~mol})$ was dissolved in acetone $(3 \mathrm{~mL})$ and cooled to $-78^{\circ} \mathrm{C}$. Ozone was bubbled through the solution until a light blue color persisted (around 30 seconds). The reaction was purged with argon for $15 \mathrm{~min}$ at which time Jones reagent $\left(0.36 \mathrm{~mL}\right.$ of $\left.1.19 \mathrm{M} \mathrm{CrO}_{3}, 0.44 \mathrm{mmol}\right)$ was added dropwise. The reaction was removed from the dry ice bath and warmed to $0{ }^{\circ} \mathrm{C}$ over $2 \mathrm{~h}$ and stirred at 0 ${ }^{\circ} \mathrm{C}$ for $1 \mathrm{~h}$. The reaction was diluted with ether and washed with brine. The organic layer was dried over $\mathrm{MgSO}_{4}$, filtered, and concentrated in vacuo. The crude carboxylic acid was directly treated with $t-\mathrm{BuOH}(1 \mathrm{~mL}), \mathrm{Boc}_{2} \mathrm{O}(0.07 \mathrm{~mL}, 0.31 \mathrm{mmol})$ and DMAP $(8$ $\mathrm{mg}, 0.07 \mathrm{mmol})$. The resulting solution was stirred overnight at room temperature at 
which time it was diluted with ether and washed with brine. The organic layer was dried over $\mathrm{MgSO}_{4}$, filtered, and concentrated in vacuo. The resulting residue was purified via flash chromatography (silica, ether/petroleum ether, gradient) to yield $34 \mathrm{mg}$ (45\%) of 60 as a white solid. $\mathrm{mp}=89-91{ }^{\circ} \mathrm{C}$. The obtained spectral data matched literature values. ${ }^{12}$ $[\alpha]_{\mathrm{D}}+8.17\left(\mathrm{c}=0.24, \mathrm{CHCl}_{3}\right)$, for $94 \%$ ee. IR (film from $\left.\mathrm{CDCl}_{3}\right): 2926,1769,1738$, 1352, 1156, 1094, $816 \mathrm{~cm}^{-1} .{ }^{1} \mathrm{H}$ NMR $\left(500 \mathrm{MHz} \mathrm{CDCl}_{3}\right) \delta 7.74$ (d, J = 8.4 Hz, $\left.2 \mathrm{H}\right), 7.33$ $(\mathrm{d}, \mathrm{J}=8.0 \mathrm{~Hz}, 2 \mathrm{H}), 4.66(\mathrm{dd}, \mathrm{J}=2.8,9.2 \mathrm{~Hz}, 1 \mathrm{H}), 3.84(\mathrm{~d}, \mathrm{~J}=17.2 \mathrm{~Hz}, 1 \mathrm{H}), 3.78(\mathrm{~d}, \mathrm{~J}$ $=17.2 \mathrm{~Hz}, 1 \mathrm{H}), 2.73(\mathrm{dd}, \mathrm{J}=9.0,18.2 \mathrm{~Hz}, 1 \mathrm{H}), 2.47(\mathrm{dd}, \mathrm{J}=3.0,18.5 \mathrm{~Hz}, 1 \mathrm{H}), 2.42$ (s, $3 \mathrm{H}), 1.36$ (s, $9 \mathrm{H}) .{ }^{13} \mathrm{C} \mathrm{NMR}\left(125 \mathrm{MHz}, \mathrm{CDCl}_{3}\right) \delta$ 206.80, 169.43, 144.30, 135.09, 129.91 (2 C), 127.43 (2 C), 83.17, 58.20, 52.62, 41.76, 29.72, 26.57 (3 C).

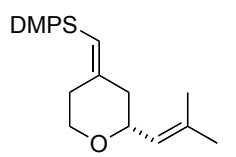

Compound 61. The metathesis procedure was performed in analogy to a literature procedure. ${ }^{13}$ Grubbs II ruthenium metathesis catalyst (23 mg, $0.027 \mathrm{mmol}$ ) was added to an oven dried, $100 \mathrm{~mL}$ Fischer-Porter bottle with Teflon stir bar. The bottle was capped with a rubber septum, flushed with argon ( 3 times to purge), and cooled to $-78{ }^{\circ} \mathrm{C}$. Compound $24(0.38 \mathrm{~g}, 1.48 \mathrm{mmol})$ was injected into the bottle. Once the substrate was frozen, a pressure regulator was attached to the bottle. The bottle was evacuated and backfilled with dry $\mathrm{N}_{2}$ three times. The bottle was evacuated once more and isobutylene (30 mL, 200 eq) was condensed into the evacuated bottle. The system was sealed and allowed to warm slowly to room temperature at which time it was transferred to an oil bath and heated to $40{ }^{\circ} \mathrm{C}$ for 19 hours. The solution was then cooled to $-78^{\circ} \mathrm{C}$ whereupon the isobutylene was slowly vented off until the pressure apparatus could be safely disassembled. $100 \mathrm{~mL} \mathrm{CH}_{2} \mathrm{Cl}_{2}$ was added and the bottle was removed from the dry ice bath. The mixture was stirred vigorously open to the air overnight. The remaining mixture was concentrated in vacuo and purified directly via flash chromatography to yield $0.27 \mathrm{~g}(63 \%) 61$ as a colorless oil and $70 \mathrm{mg}(17 \%)$ of recovered starting material. $\left[\alpha_{D}\right]-11.33(\mathrm{c}=1.49, \mathrm{DCM})$, for $94 \%$ ee. IR (film from $\mathrm{CDCl}_{3}$ ): 2954, 2846, 1620 , 1428, 1376, 1137, 1112, 1063, 1004, $873 \mathrm{~cm}^{-1}$. ${ }^{1} \mathrm{H}$ NMR (500 MHz, $\left.\mathrm{CDCl}_{3}\right): \delta 7.53(\mathrm{~m}, 2$ H), $7.34(\mathrm{~m}, 3 \mathrm{H}), 5.37$ (s, $1 \mathrm{H}), 5.18(\mathrm{~d}, \mathrm{~J}=8.0 \mathrm{~Hz}, 1 \mathrm{H}), 4.02$ (ddd, J = 11.0, 8.0, 3.0 Hz, $1 \mathrm{H}), 3.95$ (ddd, J = 11.0, 5.5, 3.0 Hz, $1 \mathrm{H}), 3.30$ (dt, J = 11.0, 3.0 Hz, $1 \mathrm{H}$ ), 2.20 (m, 4 $\mathrm{H}), 1.72(\mathrm{~s}, 3 \mathrm{H}), 1.68(\mathrm{~s}, 3 \mathrm{H}), 0.35(\mathrm{~s}, 3 \mathrm{H}), 0.34(\mathrm{~s}, 3 \mathrm{H}) .{ }^{13} \mathrm{C} \mathrm{NMR}\left(125 \mathrm{MHz}, \mathrm{CDCl}_{3}\right)$ : $\delta$ 155.48, 139.77, 136.14, 133.66 (2 C), 128.81, 127.76 (2 C), 125.54, 120.59, 76.09, $67.99,46.03,34.66,25.72,18.46,-0.65,-0.80$.

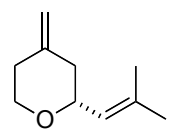

Compound 62. The desilylation was performed in analogy to a literature procedure. ${ }^{14}$ TBAF (4.5 $\mathrm{mL}$ of $1.0 \mathrm{M}$ in THF) was added to an oven dried sealed tube containing 61 $(0.24 \mathrm{~g}, 0.84 \mathrm{mmol})$ and DMSO $(8 \mathrm{~mL})$. The tube was sealed and heated in oil bath at 90 ${ }^{\circ} \mathrm{C}$ for $1 \mathrm{~h}$. The reaction was then cooled to room temperature and diluted with $40 \mathrm{~mL}$ 
ether. The solution was washed with saturated aq. $\mathrm{NaCl}$ three times $(15 \mathrm{~mL})$. The combined organic layers were dried over $\mathrm{MgSO}_{4}$ and eluted through a short plug of silica with ether. The filtrate was concentrated via distillation and purified via flash chromatography (silica, pentane/diethyl ether). The desired fractions were concentrated via distillation to yield $0.11 \mathrm{~g}(86 \%)$ of $\mathbf{6 2}$ as a light yellow oil. The obtained spectral data matched literature values. ${ }^{15}\left[\alpha_{\mathrm{D}}\right]+31.52\left(\mathrm{c}=1.00, \mathrm{CHCl}_{3}\right)$ for $94 \%$ ee. IR (neat): 2938, 1445, 1377, 1258, 1090, 1066, 1037, $887 \mathrm{~cm}^{-1} .{ }^{1} \mathrm{H}$ NMR (500 MHz, $\left.\mathrm{CDCl}_{3}\right): \delta$ $5.18(\mathrm{~d}, \mathrm{~J}=8 \mathrm{~Hz}, 1 \mathrm{H}), 4.71(\mathrm{~m}, 2 \mathrm{H}), 4.05(\mathrm{ddd}, \mathrm{J}=2.5,4.8,9.0 \mathrm{~Hz}, 1 \mathrm{H}), 3.95(\mathrm{ddd}, \mathrm{J}=$ 2.5, 8.0, $10.0 \mathrm{~Hz}, 1 \mathrm{H}), 3.41$ (ddd, J = 2.5, 11.0, $13.0 \mathrm{~Hz}, 1 \mathrm{H}), 2.28(\mathrm{~m}, 1 \mathrm{H}), 2.11(\mathrm{~m}, 3$ $\mathrm{H}), 1.71(\mathrm{~s}, 3 \mathrm{H}), 1.67(\mathrm{~s}, 3 \mathrm{H}) .{ }^{13} \mathrm{C}$ NMR $\left(125 \mathrm{MHz}, \mathrm{CDCl}_{3}\right): \delta$ 144.59, 136.18, 125.57, $108.43,75.77,68.43,41.28,35.82,25.71,18.42$.

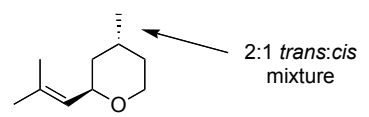

Compound 63. Wilkinson's catalyst ( $3.6 \mathrm{mg}, 0.004 \mathrm{mmol}$ ) was added to a test tube, which was then evacuated and backfilled with argon 3 times. A solution of $62(0.02 \mathrm{~g}$, $0.13 \mathrm{mmol}$ ) in $0.4 \mathrm{~mL}$ degassed benzene was added to the catalyst via cannula. The argon atmosphere was replaced with hydrogen gas and the reaction was stirred at room temperature for $3 \mathrm{~h}$. The resulting solution was directly purified via flash chromatography (silica, pentane/diethyl ether, gradient) to yield $13 \mathrm{mg}(60 \%)$ of 63 as a 2:1 inseparable mixture of trans:cis isomers. Note: product is slightly voliatile. The obtained spectral data matched literature values. ${ }^{16}$ The inseparable diastereomers were characterized as a mixture. IR (film from $\mathrm{CDCl}_{3}$ ): 2954, 2925, 2859, 1445, 1377, 1255, 1179, 1168, 1080, $1054,976,882,830 \mathrm{~cm}^{-1} .{ }^{1} \mathrm{H}$ NMR $\left(500 \mathrm{MHz} \mathrm{CDCl}_{3}\right)$ For major isomer $\delta 5.26(\mathrm{~d}, \mathrm{~J}=8.0$ $\mathrm{Hz}, 1 \mathrm{H}), 4.34$ (ddd, J = 3.5, 8.0, 8.0 Hz, $1 \mathrm{H}), 3.71(\mathrm{~m}, 2 \mathrm{H}), 1.99(\mathrm{~m}, 1 \mathrm{H}), 1.73(\mathrm{~m}, 1$ H), $1.70(\mathrm{~s}, 3 \mathrm{H}), 1.67$ (s, $3 \mathrm{H}), 1.61-1.48(\mathrm{~m}, 2 \mathrm{H}), 1.24(\mathrm{~m}, 1 \mathrm{H}), 1.04(\mathrm{~d}, \mathrm{~J}=7.0 \mathrm{~Hz}, 3$ $\mathrm{H})$. For minor isomer $\delta 5.13(\mathrm{~d}, \mathrm{~J}=8.0 \mathrm{~Hz}, 1 \mathrm{H}), 3.95(\mathrm{~m}, 2 \mathrm{H}), 3.44$ (ddd, $\mathrm{J}=2.0,12.0$, $13.0 \mathrm{~Hz}, 1 \mathrm{H}), 1.69$ (s, $3 \mathrm{H}), 1.66(\mathrm{~s}, 3 \mathrm{H}), 1.65-1.47(\mathrm{~m}, 3 \mathrm{H}), 1.20$ (m, $1 \mathrm{H}), 0.98$ (m, 1 $\mathrm{H}), 0.91(\mathrm{~d}, \mathrm{~J}=6.5 \mathrm{~Hz}, 3 \mathrm{H}) .{ }^{13} \mathrm{C}$ NMR $\left(100 \mathrm{MHz}, \mathrm{CDCl}_{3}\right)$ For major isomer $\delta 135.58$, $125.36,69.06,62.20,38.15,32.43,25.79,24.91,19.14,18.27$. For minor isomer $\delta$ $135.28,126.34,74.61,67.89,40.78,34.38,30.23,25.69,22.30,18.34$.

\section{Part IV. Synthetic Utility and Synthesis of Ring B of Bryostatin}

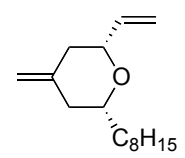

Compound 64. The desilylation was performed following a literature procedure. ${ }^{17}$ Trifluoroacetic acid $(25 \mathrm{mg}, 0.33 \mathrm{mmol})$ was added to a solution of $41(24 \mathrm{mg}, 0.08$ $\mathrm{mmol})$ in toluene $(1.5 \mathrm{~mL})$. The reaction was stirred at room temperature for $8 \mathrm{~h}$ and then directly concentrated in vacuo. The resulting oil was purified via flash chromatography (silica, ether/petroleum ether gradient) to yield $17 \mathrm{mg}(92 \%)$ of $\mathbf{6 4}$ as a colorless oil. $\mathrm{R}_{\mathrm{f}}=$ 0.8 in $5 \%$ ether/petroleum ether. $[\alpha]_{\mathrm{D}}-13.35\left(\mathrm{c}=2.34, \mathrm{CH}_{2} \mathrm{Cl}_{2}\right)$. IR (film from $\left.\mathrm{CDCl}_{3}\right)$ : 
$2929,2856,1781,1654,1466,1221,1065,922,889 \mathrm{~cm}^{-1} .{ }^{1} \mathrm{H}$ NMR $\left(500 \mathrm{MHz}, \mathrm{CDCl}_{3}\right) \delta$ 5.93 (ddd, J = 5.3, 10.5, $17.0 \mathrm{~Hz}, 1 \mathrm{H}), 5.30(\mathrm{~d}, \mathrm{~J}=17.0 \mathrm{~Hz}, 1 \mathrm{H}), 5.15(\mathrm{~d}, \mathrm{~J}=10.5 \mathrm{~Hz}, 1$ H), 4.77 (s, $2 \mathrm{H}), 3.80(\mathrm{~m}, 1 \mathrm{H}), 3.32(\mathrm{~m}, 1 \mathrm{H}), 2.29(\mathrm{~d}, \mathrm{~J}=13.5 \mathrm{~Hz}, 1 \mathrm{H}), 2.25(\mathrm{~d}, \mathrm{~J}=$ $13.0 \mathrm{~Hz}, 1 \mathrm{H}), 2.07(\mathrm{t}, \mathrm{J}=12.5 \mathrm{~Hz}, 1 \mathrm{H}), 1.95(\mathrm{t}, \mathrm{J}=12.5 \mathrm{~Hz}, 1 \mathrm{H}), 1.62(\mathrm{~m}, 2 \mathrm{H}), 1.46$ $(\mathrm{m}, 2 \mathrm{H}), 1.30(\mathrm{~m}, 10 \mathrm{H}), 0.91(\mathrm{t}, \mathrm{J}=7.0 \mathrm{~Hz}, 3 \mathrm{H}) .{ }^{13} \mathrm{C} \mathrm{NMR}\left(125 \mathrm{MHz}, \mathrm{CDCl}_{3}\right) \delta$ $144.65,138.87,115.04,108.50,78.81,78.45,40.61,40.57,36.33,31.87,29.68,29.53$, 29.26, 25.48, 22.66, 14.10. Anal calcd for $\mathrm{C}_{16} \mathrm{H}_{28} \mathrm{O}: \mathrm{C}, 81.29 \%$; H, 11.94\%. Found: C; $81.08 \% ; \mathrm{H}, 12.16 \%$.

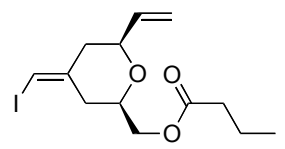

Compound 65. The iodination was performed following a literature procedure. ${ }^{18} \mathrm{~N}$ Iodosuccinimide $(0.16 \mathrm{~g}, 0.69 \mathrm{mmol})$ was added to a cooled $\left(0^{\circ} \mathrm{C}\right)$ solution of $44(0.12 \mathrm{~g}$, $0.4 \mathrm{mmol}$ ) in $10 \mathrm{~mL}$ of $\mathrm{MeCN}$. The reaction was wrapped in aluminum foil and stirred for $3 \mathrm{~h}$. The resulting solution was quenched via addition of $5 \mathrm{~mL}$ water. The aqueous layer was extracted two times with ether. The combined organic layers were washed with $20 \%$ sodium sulfite, and brine. The organic layer was dried over $\mathrm{MgSO}_{4}$ and concentrated in vacuo. The resulting oily residue was purified via flash chromatography (silica, ether/petroleum ether gradient) to yield $0.14 \mathrm{~g}(96 \%)$ of $\mathbf{6 5}$ as a colorless oil. $\mathrm{R}_{\mathrm{f}}=$ 0.5 in $10 \%$ ether / petroleum ether. $[\alpha]_{\mathrm{D}}+50.58\left(\mathrm{c}=0.22, \mathrm{CH}_{2} \mathrm{Cl}_{2}\right)$. IR (film from $\left.\mathrm{CDCl}_{3}\right): 2963,2875,1738,1253,1178,1141,1101,1062,1016 \mathrm{~cm}^{-1} .{ }^{1} \mathrm{H}$ NMR $(300$ $\left.\mathrm{MHz}, \mathrm{CDCl}_{3}\right) \delta 5.93(\mathrm{~s}, 1 \mathrm{H}), 5.76(\mathrm{ddd}, \mathrm{J}=5.4,10.5,17.1 \mathrm{~Hz}, 1 \mathrm{H}), 5.18(\mathrm{~d}, \mathrm{~J}=17.1$ $\mathrm{Hz}, 1 \mathrm{H}), 5.06(\mathrm{~d}, \mathrm{~J}=10.5 \mathrm{~Hz}, 1 \mathrm{H}), 4.09(\mathrm{~d}, \mathrm{~J}=4.8 \mathrm{~Hz}, 2 \mathrm{H}), 3.72(\mathrm{~m}, 1 \mathrm{H}), 3.48(\mathrm{~m}, 1$ H), $2.57(\mathrm{~d}, \mathrm{~J}=13.5 \mathrm{~Hz}, 1 \mathrm{H}), 2.37(\mathrm{~d}, \mathrm{~J}=13.8 \mathrm{~Hz}, 1 \mathrm{H}), 2.24(\mathrm{t}, \mathrm{J}=7.5 \mathrm{~Hz}, 2 \mathrm{H}), 2.03(\mathrm{t}$, $\mathrm{J}=12.0 \mathrm{~Hz}, 1 \mathrm{H}), 1.83(\mathrm{t}, \mathrm{J}=12.3 \mathrm{~Hz}, 1 \mathrm{H}), 1.57$ (tq, J = 7.5, 7.5 Hz, $2 \mathrm{H}), 0.85$ (t, J = $7.5 \mathrm{~Hz}, 3 \mathrm{H}) .{ }^{13} \mathrm{C} \mathrm{NMR}\left(75 \mathrm{MHz}, \mathrm{CDCl}_{3}\right) \delta 173.44,144.82,137.18,116.04,78.33,74.72$, 74.52, 66.14, 42.36, 37.62, 36.00, 18.38, 13.62.

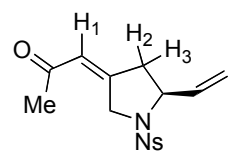

Compound 66. Acetyl chloride $(11 \mathrm{mg}, 0.14 \mathrm{mmol})$ was added to a cooled $\left(0{ }^{\circ} \mathrm{C}\right)$ solution of $\mathrm{AlCl}_{3}(17 \mathrm{mg}, 0.13 \mathrm{mmol})$ in $0.65 \mathrm{~mL} \mathrm{DCM}$. The reaction was stirred at $0{ }^{\circ} \mathrm{C}$ for $30 \mathrm{~min}$ at which time a solution of $\mathbf{1 7}(0.23 \mathrm{~g}, 0.06 \mathrm{mmol})$ in $0.35 \mathrm{~mL}$ DCM was added via syringe pump over $45 \mathrm{~min}$. The reaction was warmed to $15^{\circ} \mathrm{C}$ over $4 \mathrm{~h}$ and then quenched with saturated aq. $\mathrm{Na}_{2} \mathrm{CO}_{3}$. The aqueous layer was extracted two times with ether. The combined organic layers were dried over magnesium sulfate and concentrated in vacuo. The resulting oil was purified via flash chromatography (silica, ether/petroleum ether gradient) to yield $10 \mathrm{mg}(50 \%)$ of $\mathbf{6 6}$ as an oily white solid. $\mathrm{R}_{\mathrm{f}}=$ 0.2 in $50 \%$ ether/petroleum ether. For $92 \%$ ee, $[\alpha]_{\mathrm{D}}+71.15\left(\mathrm{c}=1.0, \mathrm{CH}_{2} \mathrm{Cl}_{2}\right) .3 \% \mathrm{nOe}$ between $\mathrm{H}_{1}$ and $\mathrm{H}_{2} .1 \%$ nOe between $\mathrm{H}_{1}$ and $\mathrm{H}_{3}$. IR (film from $\mathrm{CDCl}_{3}$ ): 1694, 1633, 
1532, 1352, 1310, 1167, 1094, 1060, 856, $687 \mathrm{~cm}^{-1} .{ }^{1} \mathrm{H}$ NMR (500 MHz, $\left.\mathrm{CDCl}_{3}\right) \delta 8.38$ $(\mathrm{d}, \mathrm{J}=9.0 \mathrm{~Hz}, 2 \mathrm{H}), 8.05(\mathrm{~d}, \mathrm{~J}=9.0 \mathrm{~Hz}, 2 \mathrm{H}), 6.25$ (s, $1 \mathrm{H}), 5.63$ (ddd, J = 17.0, 10.0, 7.5 Hz, 1 H), 5.25 (d, J = 17.0 Hz, 1 H), 5.16 (d, J = 10.0 Hz, 1 H), 4.45 (m, 3 H), 2.85 (dd, J $=17.0,8.0 \mathrm{~Hz}, 1 \mathrm{H}), 2.55(\mathrm{~d}, \mathrm{~J}=17.0 \mathrm{~Hz}, 1 \mathrm{H}), 2.22(\mathrm{~s}, 3 \mathrm{H}) .{ }^{13} \mathrm{C} \mathrm{NMR}(125 \mathrm{MHz}$, $\left.\mathrm{CDCl}_{3}\right) \delta 197.05,154.72,150.07,144.02,135.48,128.81$ (2 C), 124.26 (2 C), 120.97, 117.39, 60.68, 52.51, 40.28, 31.08. Anal calcd for $\mathrm{C}_{15} \mathrm{H}_{16} \mathrm{~N}_{2} \mathrm{O}_{5} \mathrm{~S}: \mathrm{C}, 53.56 \%$; H, 4.79\%; N, 8.33\%. Found: C, 53.92\%; H, 5.09\%; N, 7.94\%.

\section{Synthesis of Compound 67.}

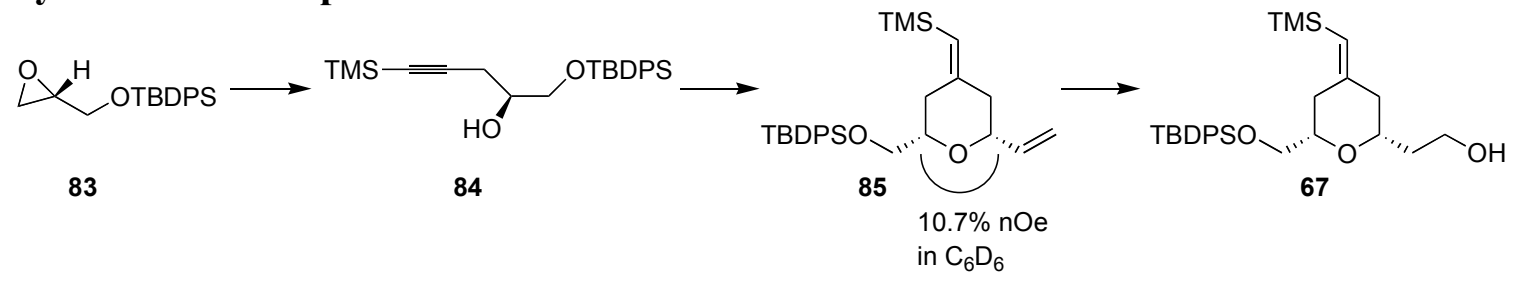

Compound 84. $n$-Butyllithium (5.0 $\mathrm{mL}$ of $2.3 \mathrm{M}$ in hexanes) was added dropwise to a cooled $\left(-78^{\circ} \mathrm{C}\right)$ solution of trimethylsilylacetylene $(1.63 \mathrm{~mL}, 11.5 \mathrm{mmol})$ in $47 \mathrm{~mL}$ diethyl ether. The mixture was stirred for $20 \mathrm{~min}$ at $-78^{\circ} \mathrm{C}$, at which time trimethylaluminum $(5.8 \mathrm{~mL}$ of $2.0 \mathrm{M}$ in hexanes $)$ was added dropwise. The solution was stirred at $-78{ }^{\circ} \mathrm{C}$ for $30 \mathrm{~min},-45^{\circ} \mathrm{C}$ for $30 \mathrm{~min}$, and then recooled to $-78^{\circ} \mathrm{C}$. A solution of $83(3.0 \mathrm{~g}, 9.6 \mathrm{mmol})$ in $6 \mathrm{~mL}$ ether is added dropwise via cannula, followed by the addition of $\mathrm{BF}_{3} \cdot \mathrm{OEt}_{2}(1.34 \mathrm{~mL}, 10.5 \mathrm{mmol})$ slowly down the sides of the flask. The resulting solution was stirred at $-78^{\circ} \mathrm{C}$ for $1 \mathrm{~h}$ at which point $\mathrm{MeOH}(5 \mathrm{~mL})$ was added and the reaction was warmed to $-25^{\circ} \mathrm{C}$. Saturated aq. $\mathrm{NH}_{4} \mathrm{Cl}$ solution was added and the resulting biphasic solution was stirred 30 min or until the emulsion broke. Water and ether were added and the resulting aqueous layer was extracted three times with ether. The combined organic layers were dried over $\mathrm{MgSO}_{4}$, filtered, concentrated in vacuo. The resulting oily residue was purified via flash chromatography (silica, $0-15 \%$ ether/petroleum ether, gradient) to yield $3.6 \mathrm{~g}(92 \%)$ of 84 as a colorless oil. $R_{f}=0.42$ in $15 \%$ ether/petroleum ether. The reaction was also performed on a $10 \mathrm{~g}$ scale (32 mmol of 83) to yield $10.5 \mathrm{~g}(80 \%)$ of 84. $[\alpha]_{\mathrm{D}}+4.78\left(\mathrm{c}=1.55, \mathrm{CH}_{2} \mathrm{Cl}_{2}\right)$. IR (neat): 3572,3466 , 2959, 2932, 2859, 2176, 1428, 1250, 1113, 760, 740, $701 \mathrm{~cm}^{-1}$. ${ }^{1} \mathrm{H}$ NMR (400 MHz, $\left.\mathrm{CDCl}_{3}\right) \delta$ 7.66-7.64 (m, $\left.4 \mathrm{H}\right), 7.44-7.35(\mathrm{~m}, 6 \mathrm{H}), 3.85(\mathrm{~m}, 1 \mathrm{H}), 3.74(\mathrm{dd}, \mathrm{J}=12.5,5.5$ $\mathrm{Hz}, 1 \mathrm{H}), 3.68(\mathrm{dd}, \mathrm{J}=12.5,7.0 \mathrm{~Hz}, 1 \mathrm{H}), 2.50(\mathrm{~d}, \mathrm{~J}=8.0 \mathrm{~Hz}, 1 \mathrm{H}), 2.49(\mathrm{~d}, \mathrm{~J}=8.5 \mathrm{~Hz}, 1$ $\mathrm{H}), 1.06(\mathrm{~s}, 9 \mathrm{H}), 0.09(\mathrm{~s}, 9 \mathrm{H})$. The hydroxyl proton was not observed. ${ }^{13} \mathrm{C}$ NMR $(100$ $\mathrm{MHz}, \mathrm{CDCl}_{3}$ ) $\delta 135.51$ (4 C), 133.04 (2 C), 129.82 (2 C), 127.78 (4 C), 102.61, 87.10, 70.21, 66.35, 26.83 (3 C), 24.64, 19.27, 0.00 (3 C). Anal calcd for $\mathrm{C}_{24} \mathrm{H}_{34} \mathrm{O}_{2} \mathrm{Si}_{2}: \mathrm{C}$, $70.19 \%$; H, 8.34\%. Found: C, 70.27\%; H, 8.18\%.

Compound 85. Following Condition $\mathrm{D}$ : $\left[\mathrm{CpRu}\left(\mathrm{CH}_{3} \mathrm{CN}\right)_{3}\right] \mathrm{PF}_{6}(0.97 \mathrm{~g}, 2.23 \mathrm{mmol})$ was added to a cooled $\left(0{ }^{\circ} \mathrm{C}\right)$ solution of $\mathbf{8 4}(9.2 \mathrm{~g}, 22.3 \mathrm{mmol})$ and $\mathbf{1 5}(19.1 \mathrm{~g}, 98.7 \mathrm{mmol})$ in $112 \mathrm{~mL}$ in degassed acetone under argon. The reaction was stirred at $0{ }^{\circ} \mathrm{C}$ for $5 \mathrm{~min}$ at which time it was removed from the ice bath and stirred at room temperature under argon 
for $4 \mathrm{~h}$. The resulting solution was directly concentrated in vacuo. The resulting oily residue was purged with argon three times and dissolved in $310 \mathrm{~mL}$ rigorously degassed DCM. Triethylamine $(3.3 \mathrm{~mL}, 23.4 \mathrm{mmol})$ was added followed by a solution of $\mathrm{Pd}_{2} \mathrm{dba}_{3} \cdot \mathrm{CHCl}_{3}(0.46 \mathrm{~g}, 0.45 \mathrm{mmol})$ and $(R, R)-\mathbf{L}-1(0.92 \mathrm{~g}, 1.34 \mathrm{mmol})$ in $10 \mathrm{~mL}$ DCM. The resulting red solution was stirred for $1.5 \mathrm{~h}$ at $0{ }^{\circ} \mathrm{C}$ at which point the mixture was concentrated in vacuo. The resulting oily residue was purified via flash chromatography (silica, ether/petroleum ether, gradient) to yield $9.8 \mathrm{~g}(94 \%)$ of $\mathbf{8 5}$ as a colorless oil. $\mathrm{R}_{\mathrm{f}}=$ 0.8 in $15 \%$ ether/petroleum ether. $[\alpha]_{\mathrm{D}}-13.37\left(\mathrm{c}=1.39, \mathrm{CH}_{2} \mathrm{Cl}_{2}\right)$. IR (neat): 2955, 2858, $1623,1473,1248,1188,1114,768,740,701 \mathrm{~cm}^{-1} .{ }^{1} \mathrm{H}$ NMR $\left(500 \mathrm{MHz}, \mathrm{C}_{6} \mathrm{D}_{6}\right) \delta 7.83-$ 7.79 (m, 4 H), 7.25-7.22 (m, 6 H), 5.84 (ddd, J = 17.5, 11.0, 5.5 Hz, 1 H), 5.32 (s, 1 H), $5.27(\mathrm{dt}, \mathrm{J}=17.5,1.5 \mathrm{~Hz}, 1 \mathrm{H}), 5.01(\mathrm{dt}, \mathrm{J}=11.0,1.5 \mathrm{~Hz}, 1 \mathrm{H}), 3.97$ (dd, J = 10.0, 5.0 $\mathrm{Hz}, 1 \mathrm{H}), 3.82-3.78(\mathrm{~m}, 1 \mathrm{H}), 3.76(\mathrm{dd}, \mathrm{J}=10.0,6.0 \mathrm{~Hz}, 1 \mathrm{H}), 3.62-3.57(\mathrm{~m}, 1 \mathrm{H}), 2.78$ $(\mathrm{dt}, \mathrm{J}=13.0,2.0 \mathrm{~Hz}, 1 \mathrm{H}), 2.19-2.11(\mathrm{~m}, 2 \mathrm{H}), 2.00(\mathrm{t}, \mathrm{J}=13.0 \mathrm{~Hz}, 1 \mathrm{H}), 1.19(\mathrm{~s}, 9 \mathrm{H})$, $0.21(\mathrm{~s}, 9 \mathrm{H}) .{ }^{13} \mathrm{C} \mathrm{NMR}\left(125 \mathrm{MHz}, \mathrm{CDCl}_{3}\right) \delta 152.97,138.58,135.65$ (2 C), 135.61 (2 C), 133.52, 133.50, 129.60 (2 C), 127.61 (4 C), 123.58, 115.18, 79.24, 78.28, 66.93, 45.47, 37.03, 26.82 (3 C), 19.25, 0.27 (3 C). Anal calcd for $\mathrm{C}_{28} \mathrm{H}_{40} \mathrm{O}_{2} \mathrm{Si}_{2}: \mathrm{C}, 72.36 \%$; $\mathrm{H}, 8.67 \%$. Found: C, $72.16 \%$; H, 8.83\%.

Compound 67. Catecholborane $(4.5 \mathrm{~mL}, 42.3 \mathrm{mmol})$ was added to a cooled $\left(0{ }^{\circ} \mathrm{C}\right)$ solution of $85(6.6 \mathrm{~g}, 14.1 \mathrm{mmol})$ and Wilkinson's catalyst $(0.39 \mathrm{~g}, 0.42 \mathrm{mmol})$ in 140 $\mathrm{mL}$ of THF. The ice bath was removed and the reaction was stirred at room temperature for $1 \mathrm{~h}$. The resulting dark brown solution was cooled to $0{ }^{\circ} \mathrm{C}$ at which point an aqueous solution of $\mathrm{NaBO}_{3}$ (14 g in $140 \mathrm{~mL}$ water) was added. The ice bath was removed and the resulting biphasic solution was stirred vigorously at room temperature for $4 \mathrm{~h}$. Ether and water were added and the resulting aqueous layer was extracted three times with ether. The combined organic layers were dried over $\mathrm{MgSO}_{4}$, filtered, and concentrated in vacuo. The resulting oily residue was purified via flash chromatography (silica, ether/petroleum ether, gradient) to yield an inseparable mixture of 67 and catechol. $R_{f}=$ 0.3 in $50 \%$ ether/petroleum ether. The mixture was taken up in diethyl ether and washed four times with saturated aq. $\mathrm{Na}_{2} \mathrm{CO}_{3}$ solution to remove the catechol by-product. The resulting solution was dried over $\mathrm{MgSO}_{4}$, filtered, and concentrated in vacuo to yield 5.3 $\mathrm{g}(78 \%)$ of pure 67 as a light yellow oil. $[\alpha]_{\mathrm{D}}-3.73\left(\mathrm{c}=4.66, \mathrm{CH}_{2} \mathrm{Cl}_{2}\right)$. IR (film from $\left.\mathrm{CH}_{2} \mathrm{Cl}_{2}\right): 3442,3071,2953,2858,1623,1472,1248,1113,841,740,701 \mathrm{~cm}^{-1} .{ }^{1} \mathrm{H}$ NMR

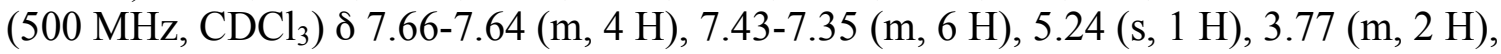
$3.72(\mathrm{dd}, \mathrm{J}=10.5,5.5 \mathrm{~Hz}, 1 \mathrm{H}), 3.61-3.56(\mathrm{~m}, 1 \mathrm{H}), 3.54(\mathrm{dd}, \mathrm{J}=10.5,5.5 \mathrm{~Hz}, 1 \mathrm{H}), 3.45$ (dddd, J = 11.0, 5.5, 5.5, 2.0 Hz, $1 \mathrm{H}$ ), 2.76 (br s, $1 \mathrm{H}$ ), 2.52 (dt, J = 13.5, $2.0 \mathrm{~Hz}, 1 \mathrm{H}$ ), 2.18-2.09 (m, $2 \mathrm{H}), 1.87$ (t, J = 12.5 Hz, $1 \mathrm{H}), 1.81-1.75(\mathrm{~m}, 1 \mathrm{H}), 1.74-1.66(\mathrm{~m}, 1 \mathrm{H})$, $1.04(\mathrm{~s}, 9 \mathrm{H}), 0.72(\mathrm{~s}, 9 \mathrm{H}) .{ }^{13} \mathrm{C} \mathrm{NMR}\left(100 \mathrm{MHz}, \mathrm{CDCl}_{3}\right) \delta 152.65,135.60$ (2 C), 135.58 (2 C), 133.35, 133.33, 129.69, 127.70 (4 C), 123.75, 123.71, 79.53, 78.78, 66.86, 61.63, 45.56, 37.76, 36.55, 26.74 (3 C), 19.16, 0.24 (3 C). Anal calcd for $\mathrm{C}_{28} \mathrm{H}_{42} \mathrm{O}_{3} \mathrm{Si}_{2}$ : C, 69.66\%; H, 8.77\%. Found: C, 69.75\%; H, 8.61\%.

\section{Synthesis of Compound 68.}




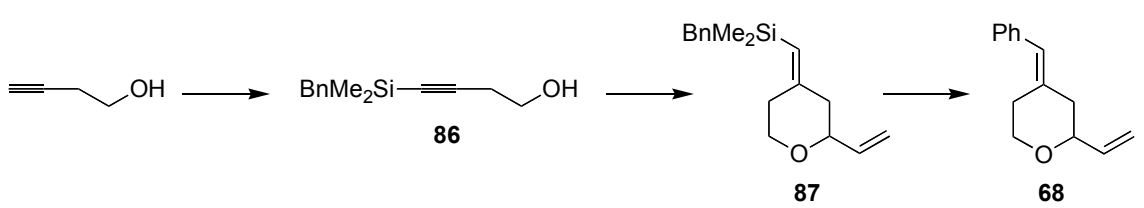

Compound 86. $n$-Butyllithium (2.0 mL of $1.6 \mathrm{M}$ in hexanes) was added to a cooled (-78 $\left.{ }^{\circ} \mathrm{C}\right)$ solution of 2-but-3-ynyloxy-tetrahydro-pyran $(0.46 \mathrm{~g}, 2.96 \mathrm{mmol})$ in THF $(15 \mathrm{~mL})$. The resulting colorless solution was stirred at $-78{ }^{\circ} \mathrm{C}$ for $30 \mathrm{~min}$ at which time benzyldimethylsilylchloride $(0.6 \mathrm{~g}, 3.25 \mathrm{mmol})$ was added. The resulting colorless solution was stirred at $-78{ }^{\circ} \mathrm{C}$ for $5 \mathrm{~h}$. The reaction was quenched with $\mathrm{NH}_{4} \mathrm{Cl}$ and the aqueous layer was extracted three times with ether. The combined organic layers were dried over magnesium sulfate, filtered, and concentrated in vacuo. The resulting oily residue was purified via flash chromatography (silica, ether/petroleum ether gradient) to yield $0.88 \mathrm{~g}(98 \%)$ of silylalkyne as a colorless oil. $\mathrm{R}_{\mathrm{f}}=0.5 \mathrm{in} 10 \%$ ether/petroleum ether. The silylalkyne $(0.85 \mathrm{~g}, 2.81 \mathrm{mmol})$ was dissolved in methanol $(14 \mathrm{~mL})$ at which time PPTS $(0.11 \mathrm{~g}, 0.43 \mathrm{mmol})$ was added. The resulting colorless solution was stirred overnight at room temperature. The reaction was quenched by addition of saturated aq. $\mathrm{NaCl}$. The aqueous layer was extracted three times with ethyl acetate. The combined organics were dried over magnesium sulfate, filtered, and concentrated in vacuo. The resulting oily residue was purified via flash chromatography (silica, ether/petroleum ether gradient) to yield $0.59 \mathrm{~g}(96 \%)$ of $\mathbf{8 6}$ as a colorless oil. $\mathrm{R}_{\mathrm{f}}=0.35$ in $50 \%$ ether/petroleum ether. IR (neat): 3367, 3060, 3025, 2960, 2894, 2176, 1600, 1494, 1452, 1411, 1329, $1250,1208,1156,1057,1030,891,840,796,763,699 \mathrm{~cm}^{-1} .{ }^{1} \mathrm{H}$ NMR $\left(500 \mathrm{MHz}, \mathrm{CDCl}_{3}\right)$

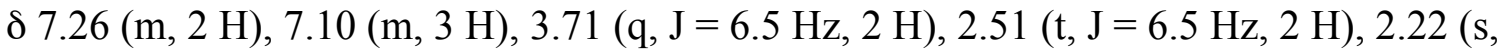
$2 \mathrm{H}), 0.17$ (s, $6 \mathrm{H})$. Hydroxyl proton was not observed. ${ }^{13} \mathrm{C} \mathrm{NMR}\left(125 \mathrm{MHz}, \mathrm{CDCl}_{3}\right)$ $\delta$ 139.09, 128.25, 128.13, 124.35, 104.91, 85.28, 60.78, 26.30, 24.24, -1.98. Anal calcd for $\mathrm{C}_{13} \mathrm{H}_{18} \mathrm{OSi}$ : C, $71.50 \%$; H, 8.31\%. Found: $\mathrm{C}, 71.70 \% ; \mathrm{H}, 8.23 \%$.

Compound 87. $\mathrm{CpRu}\left(\mathrm{CH}_{3} \mathrm{CN}\right)_{3} \mathrm{PF}_{6}(91 \mathrm{mg}, 0.21 \mathrm{mmol})$ was added to cooled $\left(0{ }^{\circ} \mathrm{C}\right)$ solution of $\mathbf{8 6}(0.46 \mathrm{~g}, 2.1 \mathrm{mmol})$ and $\mathbf{1 5}(2.3 \mathrm{~g}, 11.9 \mathrm{mmol})$ in degassed acetone $(10.5$ $\mathrm{mL}$ ). The resulting solution was stirred at room temperature for $6 \mathrm{~h}$ at which time it was concentrated in vacuo. The resulting oily residue was purified via flash chromatography (silica, ether/petroleum ether gradient) to yield $0.16 \mathrm{~g}(21 \%)$ of 1,4-diene intermediate as a colorless oil. $0.37 \mathrm{~g} \mathrm{(81 \% )}$ of starting 86 was also recovered after chromatography. The 1,4-diene intermediate $(0.33 \mathrm{~g}, 0.8 \mathrm{mmol})$ was then dissolved in $9 \mathrm{~mL}$ degassed DCM and cooled to $0{ }^{\circ} \mathrm{C}$. Triethylamine $(0.12 \mathrm{~mL}, 0.88 \mathrm{mmol})$ was added followed by a solution of $\mathrm{Pd}_{2}(\mathrm{dba})_{3} \cdot \mathrm{CHCl}_{3}(16 \mathrm{mg}, 0.015 \mathrm{mmol})$ and $(\mathrm{rac})-\mathbf{L}-1(33 \mathrm{mg}, 0.048 \mathrm{mmol})$ in 1 $\mathrm{mL} \mathrm{DCM}$. The resulting orange solution was stirred at $0{ }^{\circ} \mathrm{C}$ for $2 \mathrm{~h}$ at which time it was concentrated in vacuo. The resulting oily residue was purified via flash chromatography (silica, ether/petroleum ether gradient) to yield $0.17 \mathrm{~g}(78 \%)$ of 87 as a colorless oil. $\mathrm{R}_{\mathrm{f}}=$ 0.8 in $50 \%$ ether/petroleum ether. IR (neat): 2955, 2894, 2845, 1622, 1494, 1452, 1256, $1207,1140,1089,1058,835,792,763,699,661 \mathrm{~cm}^{-1} .{ }^{1} \mathrm{H}$ NMR $\left(500 \mathrm{MHz}, \mathrm{CDCl}_{3}\right) \delta$ $7.21(\mathrm{t}, \mathrm{J}=7.5 \mathrm{~Hz}, 2 \mathrm{H}), 7.07$ (t, J = 7.5 Hz, $1 \mathrm{H}), 7.01(\mathrm{~d}, \mathrm{~J}=8.0 \mathrm{~Hz}, 2 \mathrm{H}), 5.86$ (ddd, J = $5.5,10.5,16.5 \mathrm{~Hz}, 1 \mathrm{H}), 5.25(\mathrm{~d}, \mathrm{~J}=16.5 \mathrm{~Hz}, 1 \mathrm{H}), 5.22(\mathrm{~s}, 1 \mathrm{H}), 5.13(\mathrm{~d}, \mathrm{~J}=10.5 \mathrm{~Hz}, 1$ 
H), 4.04 (dt, J = 10.5, 3.5 Hz, $1 \mathrm{H}), 3.79(\mathrm{~m}, 1 \mathrm{H}), 3.30$ (dt, J = 10.5, 7.5 Hz, $1 \mathrm{H}), 2.20$ (m, $4 \mathrm{H}), 2.15$ (s, $2 \mathrm{H}), 0.10$ (s, $3 \mathrm{H}), 0.09$ (s, $3 \mathrm{H}) .{ }^{13} \mathrm{C} \mathrm{NMR}\left(75 \mathrm{MHz}, \mathrm{CDCl}_{3}\right.$ ) $\delta$ 154.17, 140.01, 138.54, 128.20 (2 C), 128.11 (2 C), 124.01, 121.21, 115.27, 79.40, 68.08, 45.59, $34.49,26.79,-1.56$ (2 C). Anal calcd for $\mathrm{C}_{17} \mathrm{H}_{24} \mathrm{OSi}$ C, $74.94 \%$; $\mathrm{H}, 8.88 \%$. Found: $\mathrm{C}$, $75.12 \% ; \mathrm{H}, 9.00 \%$.

Compound 68. $\mathrm{PhI}(62 \mathrm{mg}, 0.30 \mathrm{mmol})$ and TBAF $(0.4 \mathrm{~mL}$ of $1.0 \mathrm{M}$ in THF) were added sequentially to a cooled $\left(0{ }^{\circ} \mathrm{C}\right)$ solution of $87(56 \mathrm{mg}, 0.20 \mathrm{mmol})$ in $0.6 \mathrm{~mL}$ THF. The resulting solution was stirred for $15 \mathrm{~min}$ at $0^{\circ} \mathrm{C}$ at which time $\mathrm{Pd}_{2}\left(\mathrm{dba}_{3} \cdot{ }^{\cdot} \mathrm{CHCl}_{3}(5.0\right.$ $\mathrm{mg}, 0.0048 \mathrm{mmol}$ ) was added. The reaction was removed from the ice bath and stirred at room temperature for $2.5 \mathrm{~h}$. The resulting solution was flushed through a plug of silica, eluting with ether. The filtrate was concentrated in vacuo. The resulting oily residue was purified via flash chromatography (silica, ether/petroleum ether gradient) to yield $34 \mathrm{mg}$ $(85 \%)$ of $\mathbf{6 8}$ as a colorless oil. $\mathrm{R}_{\mathrm{f}}=0.78$ in $25 \%$ ether/petroleum ether. IR (film from $\left.\mathrm{CDCl}_{3}\right): 2959,2849,1655,1492,1446,1353,1257,1156,991,922,846,745,700 \mathrm{~cm}^{-1}$. ${ }^{1} \mathrm{H}$ NMR $\left(300 \mathrm{MHz}, \mathrm{CDCl}_{3}\right) \delta 7.36(\mathrm{~m}, 2 \mathrm{H}), 7.26(\mathrm{~m}, 3 \mathrm{H}), 6.40(\mathrm{~s}, 1 \mathrm{H}), 5.96$ (ddd, J = $5.7 \mathrm{~Hz}, 10.5 \mathrm{~Hz}, 17.1 \mathrm{~Hz}, 1 \mathrm{H}), 5.35(\mathrm{dt}, \mathrm{J}=17.1,1.5 \mathrm{~Hz}, 1 \mathrm{H}), 5.21(\mathrm{dt}, \mathrm{J}=10.5,1.5 \mathrm{~Hz}$, $1 \mathrm{H}), 4.11(\mathrm{dq}, \mathrm{J}=1.5 \mathrm{~Hz}, 5.7 \mathrm{~Hz}, 1 \mathrm{H}), 3.95(\mathrm{~m}, 1 \mathrm{H}), 3.47(\mathrm{dt}, \mathrm{J}=1.5,11.4 \mathrm{~Hz}, 1 \mathrm{H})$, $2.78(\mathrm{~d}, \mathrm{~J}=14.1 \mathrm{~Hz}, 1 \mathrm{H}), 2.36(\mathrm{~m}, 3 \mathrm{H}) .{ }^{13} \mathrm{C} \mathrm{NMR}\left(75 \mathrm{MHz}, \mathrm{CDCl}_{3}\right) \delta 138.58,137.35$, 137.16, 128.83 (2 C), 128.15 (2 C), 126.30, 124.31, 115.40, 79.28, 67.81, 42.45, 30.00. Anal calcd for $\mathrm{C}_{14} \mathrm{H}_{16} \mathrm{O}: \mathrm{C}, 83.96 \% ; \mathrm{H}, 8.05 \%$. Found: C, 83.73\%; H, 7.98\%.

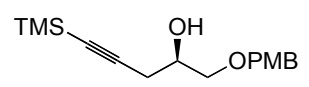

Compound 71. $n$-Butyllithium (3.9 $\mathrm{mL}$ of $1.6 \mathrm{M}$ in hexanes) was added dropwise to a cooled $\left(-78^{\circ} \mathrm{C}\right)$ solution of trimethylsilylacetylene $(0.67 \mathrm{~g}, 6.8 \mathrm{mmol})$ in $16 \mathrm{~mL}$ THF. The resulting solution was stirred for $30 \mathrm{~min}$ at $-78{ }^{\circ} \mathrm{C}$, at which time $\mathbf{7 0}^{19}(1.10 \mathrm{~g}, 5.66$ mmol) was added followed by $\mathrm{BF}_{3} \cdot \mathrm{OEt}_{2}(0.96 \mathrm{~g}, 6.8 \mathrm{mmol})$. The resulting colorless solution was stirred at $-78{ }^{\circ} \mathrm{C}$ for $3 \mathrm{~h}$. The reaction was quenched at $-78{ }^{\circ} \mathrm{C}$ with saturated aq. $\mathrm{NH}_{4} \mathrm{Cl}$. The aqueous layer was extracted three times with ether. The combined organic layers were dried over magnesium sulfate, filtered, and concentrated in vacuo. The resulting oily residue was purified via flash chromatography (silica, ether/petroleum ether gradient) to yield $0.99 \mathrm{~g}(60 \%) 71$ as a colorless oil. The enantiomeric excess was determined to be $98 \%$ via HPLC analysis. (Chiralcel OD column, 90:10 heptane:iPrOH, flow rate $=1.0 \mathrm{~mL} / \mathrm{min}, 254 \mathrm{~nm}, \mathrm{t}_{\mathrm{r}}: 5.93$ (major), 6.71 (minor)). For ee $=98 \%,[\alpha]_{\mathrm{D}}-$ $11.66\left(\mathrm{c}=1.78, \mathrm{CH}_{2} \mathrm{Cl}_{2}\right) . \mathrm{R}_{\mathrm{f}}=0.5$ in $60 \%$ ether/petroleum ether. IR (film from $\mathrm{CDCl}_{3}$ ): 3448, 2956, 2176, 1612, 1514, 1249, 1101, 1036, 843, $760 \mathrm{~cm}^{-1} .{ }^{1} \mathrm{H}$ NMR (300 MHz, $\left.\mathrm{CDCl}_{3}\right) \delta 7.29(\mathrm{~d}, \mathrm{~J}=8.5 \mathrm{~Hz}, 2 \mathrm{H}), 6.91(\mathrm{~d}, \mathrm{~J}=8.5 \mathrm{~Hz}, 2 \mathrm{H}), 4.53(\mathrm{~s}, 2 \mathrm{H}), 3.96(\mathrm{~m}, 1 \mathrm{H})$, $3.83(\mathrm{~s}, 3 \mathrm{H}), 3.61(\mathrm{dd}, \mathrm{J}=9.5,4.0 \mathrm{~Hz}, 1 \mathrm{H}), 3.49(\mathrm{dd}, \mathrm{J}=10,6.5 \mathrm{~Hz}, 1 \mathrm{H}), 2.50(\mathrm{~m}, 2 \mathrm{H})$, $2.46(\mathrm{~m}, 1 \mathrm{H}), 0.16(\mathrm{~s}, 9 \mathrm{H}) .{ }^{13} \mathrm{C} \mathrm{NMR}\left(75 \mathrm{MHz}, \mathrm{CDCl}_{3}\right) \delta$ 159.28, 129.90, 129.39 (2 C), 113.82 (2 C), 102.49, 87.24, 73.04, 72.41, 68.79, 55.25, 24.95, 0.00 (3 C). Anal calcd for $\mathrm{C}_{16} \mathrm{H}_{24} \mathrm{O}_{3} \mathrm{Si}: \mathrm{C}, 65.71 \%$; H, 8.27\%. Found: $\mathrm{C}, 65.60 \%$; H, 8.22\%. 
Synthesis of Compound 73:

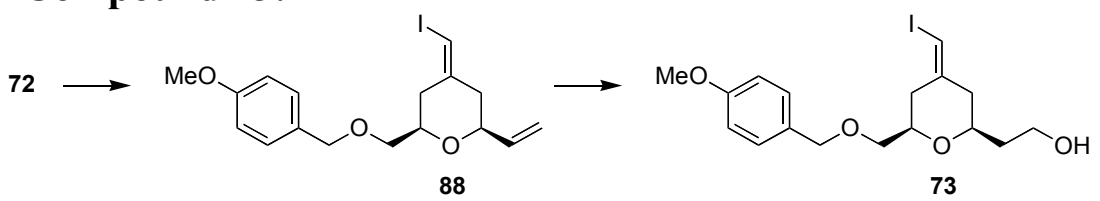

Compound 88. The iodination was performed following a literature procedure. ${ }^{18} \mathrm{~N}$ Iodosuccinimide $(0.66 \mathrm{~g}, 2.92 \mathrm{mmol})$ was added to a cooled $\left(0^{\circ} \mathrm{C}\right)$ solution of $72(0.60 \mathrm{~g}$, $1.72 \mathrm{mmol}$ ) in $40 \mathrm{~mL}$ of $\mathrm{MeCN}$. The reaction was wrapped in aluminum foil and stirred for $2 \mathrm{~h}$. The resulting solution was quenched via addition of $5 \mathrm{~mL}$ water. The aqueous layer was extracted two times with ether. The combined organic layers were washed with $20 \%$ sodium sulfite and brine. The organic layer was dried over $\mathrm{MgSO}_{4}$ and concentrated in vacuo. The resulting oily residue was purified via flash chromatography (silica, ether/petroleum ether gradient) to yield $0.62 \mathrm{~g}(90 \%)$ of $\mathbf{8 8}$ as a colorless oil, $\mathrm{R}_{\mathrm{f}}=0.9 \mathrm{in}$ 3:2 petroleum ether/ether, $[\alpha]_{\mathrm{D}}+25.01\left(\mathrm{c}=1.35, \mathrm{CH}_{2} \mathrm{Cl}_{2}\right)$. IR (film from $\left.\mathrm{CDCl}_{3}\right): 2859$, $1612,1513,1248,1098,1035,928,820 \mathrm{~cm}^{-1} .{ }^{1} \mathrm{H}$ NMR $\left(500 \mathrm{MHz}, \mathrm{CDCl}_{3}\right) \delta 7.31(\mathrm{~d}, \mathrm{~J}=$ $8.0 \mathrm{~Hz}, 2 \mathrm{H}), 6.91(\mathrm{~d}, \mathrm{~J}=8.5 \mathrm{~Hz}, 2 \mathrm{H}), 6.02(\mathrm{~s}, 1 \mathrm{H}), 5.91$ (ddd, J = 17.0, 11.0, $6.0 \mathrm{~Hz}, 1$ H), $5.31(\mathrm{~d}, \mathrm{~J}=17.0 \mathrm{~Hz}, 1 \mathrm{H}), 5.19(\mathrm{~d}, \mathrm{~J}=11.0 \mathrm{~Hz}, 1 \mathrm{H}), 4.58(\mathrm{~d}, \mathrm{~J}=12.0 \mathrm{~Hz}, 1 \mathrm{H}), 4.55$ (d, J = 12.0 Hz, $1 \mathrm{H}), 3.85$ (m, $1 \mathrm{H}), 3.84(\mathrm{~s}, 3 \mathrm{H}), 3.57$ (m, $3 \mathrm{H}), 2.69$ (d, J = 14.0 Hz, 1 $\mathrm{H}), 2.48(\mathrm{~d}, \mathrm{~J}=13.5 \mathrm{~Hz}, 1 \mathrm{H}), 2.16(\mathrm{t}, \mathrm{J}=12.0 \mathrm{~Hz}, 1 \mathrm{H}), 1.98(\mathrm{~m}, 1 \mathrm{H}) .{ }^{13} \mathrm{C}$ NMR $(125$ $\mathrm{MHz}, \mathrm{CDCl}_{3}$ ) $\delta 159.17,145.52,137.49,130.21,129.38$ (2 C), 115.91, 113.75 (2 C), 78.44, 76.34, 74.03, 73.09, 72.46, 55.26, 42.52, 37.98. Anal calcd for $\mathrm{C}_{17} \mathrm{H}_{21} \mathrm{IO}_{3}: \mathrm{C}$, $51.01 \%$; H, 5.29\%. Found: C, 50.83\%; H, 5.18\%.

Compound 73. A solution of $\mathrm{Pd}_{2}(\mathrm{dba})_{3} \cdot \mathrm{CHCl}_{3}(2.9 \mathrm{mg}, 0.0028 \mathrm{mmol})$ and diphenylphosphinopropane ( $3.5 \mathrm{~g}, 0.0085 \mathrm{mmol})$ in $0.2 \mathrm{~mL} \mathrm{MeCN} / \mathrm{MeOH}(2: 1 \mathrm{ratio})$ was added to a solution of $\mathbf{8 8}(19 \mathrm{mg}, 0.047 \mathrm{mmol})$ and $\mathrm{NEt}_{3}(0.025 \mathrm{~mL}, 0.18 \mathrm{mmol})$ in 0.2 $\mathrm{mL} \mathrm{MeCN} / \mathrm{MeOH}$ (2:1 ratio) under a $\mathrm{CO}$ atmosphere. The reaction flask was backfilled with $\mathrm{CO}$ three times and sealed. The resulting solution was stirred at $60{ }^{\circ} \mathrm{C}$ for $7 \mathrm{~h}$ at which time it was diluted with ether and brine. The aqueous layer was extracted two times with ether. The combined organic layers were dried over magnesium sulfate, filtered, and concentrated in vacuo. The resulting oily residue was purified via flash chromatography (silica, ether/petroleum ether gradient) to yield $10 \mathrm{mg}(65 \%)$ of $\mathbf{7 3}$ as a colorless oil. $\mathrm{R}_{\mathrm{f}}=0.7$ in 3:2 petroleum ether:ether. $[\alpha]_{\mathrm{D}}+29.12\left(\mathrm{c}=0.92, \mathrm{CH}_{2} \mathrm{Cl}_{2}\right)$. IR (film from $\mathrm{CDCl}_{3}$ ): 2916, 2851, 1718, 1654, 1612, 1586, 1438, 1302, 1208, 1177, 1098 $\mathrm{cm}^{-1} .{ }^{1} \mathrm{H}$ NMR $\left(500 \mathrm{MHz}, \mathrm{CDCl}_{3}\right) \delta 7.30(\mathrm{~d}, \mathrm{~J}=9.0 \mathrm{~Hz}, 2 \mathrm{H}), 6.90(\mathrm{~d}, \mathrm{~J}=9.0 \mathrm{~Hz}, 2 \mathrm{H})$, $5.93(\mathrm{ddd}, \mathrm{J}=17.0,10.5,6.0 \mathrm{~Hz}, 1 \mathrm{H}), 5.75(\mathrm{~s}, 1 \mathrm{H}), 5.31(\mathrm{~d}, \mathrm{~J}=17.0 \mathrm{~Hz}, 1 \mathrm{H}), 5.19(\mathrm{~d}, \mathrm{~J}$ $=10.5 \mathrm{~Hz}, 1 \mathrm{H}), 4.57(\mathrm{~d}, \mathrm{~J}=12.0 \mathrm{~Hz}, 1 \mathrm{H}), 4.54(\mathrm{~d}, \mathrm{~J}=12.0 \mathrm{~Hz}, 1 \mathrm{H}), 3.93(\mathrm{~m}, 1 \mathrm{H}), 3.83$ $(\mathrm{s}, 3 \mathrm{H}), 3.80(\mathrm{~m}, 1 \mathrm{H}), 3.71(\mathrm{~s}, 3 \mathrm{H}), 3.64(\mathrm{~m}, 1 \mathrm{H}), 3.57(\mathrm{~d}, \mathrm{~J}=5.0 \mathrm{~Hz}, 2 \mathrm{H}), 2.27(\mathrm{~m}, 2$ H), $2.02(\mathrm{t}, \mathrm{J}=12.0 \mathrm{~Hz}, 1 \mathrm{H}) .{ }^{13} \mathrm{C}$ NMR $\left(125 \mathrm{MHz}, \mathrm{CDCl}_{3}\right) \delta 166.76,159.16,156.66$, 137.83, 130.23, 129.39 (2 C), 115.96, 114.82, 113.75 (2 C), 78.71, 76.88, 73.08, 72.60, 55.26, 51.04, 42.28, 32.21. Anal calcd for $\mathrm{C}_{19} \mathrm{H}_{24} \mathrm{O}_{5}$ : C, 68.66\%; H, 7.28\%. Found: $\mathrm{C}$, $68.83 \%$; H, 7.40\%. 


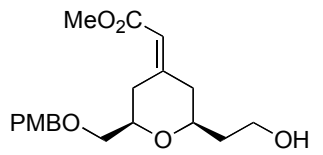

Compound 74. A solution of $\mathrm{Pd}_{2}(\mathrm{dba})_{3} \cdot \mathrm{CHCl}_{3}(2.9 \mathrm{mg}, 0.0028 \mathrm{mmol})$ and diphenylphosphinopropane $(3.5 \mathrm{mg}, 0.0085 \mathrm{mmol})$ in $0.2 \mathrm{~mL} \mathrm{MeCN} / \mathrm{MeOH}$ (2:1 ratio) was added to a solution of $73(20 \mathrm{mg}, 0.047 \mathrm{mmol})$ and $\mathrm{NEt}_{3}(0.025 \mathrm{~mL}, 0.18 \mathrm{mmol})$ in $0.2 \mathrm{~mL} \mathrm{MeCN} / \mathrm{MeOH}$ (2:1 ratio) under a $\mathrm{CO}$ atmosphere. The reaction flask was backfilled with $\mathrm{CO}$ three times and sealed. The resulting solution was stirred at $60{ }^{\circ} \mathrm{C}$ for $7 \mathrm{~h}$ at which time it was diluted with ether and brine. The aqueous layer was extracted two times with ether. The combined organic layers were dried over magnesium sulfate, filtered, and concentrated in vacuo. The resulting oily residue was purified via flash chromatography (silica, ether/petroleum ether gradient) to yield $14 \mathrm{mg}(83 \%)$ of 74 as a colorless oil, $\mathrm{R}_{\mathrm{f}}=0.1$ in 1:3 petroleum ether:ether, $[\alpha]_{\mathrm{D}}+23.07\left(\mathrm{c}=0.69, \mathrm{CH}_{2} \mathrm{Cl}_{2}\right)$. IR (film from $\mathrm{CDCl}_{3}$ ): 3447, 2923, 1716, 1652, 1514, 1436, 1248, 1153, 1092, 1034, 820 $\mathrm{cm}^{-1} .{ }^{1} \mathrm{H}$ NMR $\left(500 \mathrm{MHz}, \mathrm{CDCl}_{3}\right) \delta 7.28(\mathrm{~d}, \mathrm{~J}=8.5 \mathrm{~Hz}, 2 \mathrm{H}), 6.91(\mathrm{~d}, \mathrm{~J}=8.5 \mathrm{~Hz}, 2 \mathrm{H})$, $5.73(\mathrm{~s}, 1 \mathrm{H}), 4.52(\mathrm{~m}, 2 \mathrm{H}), 3.83$ (broad s, $5 \mathrm{H}), 3.70$ (s, $3 \mathrm{H}), 3.67$ (m, $2 \mathrm{H}), 3.53$ (m, 2 H), 2.80 (broad s, $1 \mathrm{H}), 2.22(\mathrm{~m}, 2 \mathrm{H}), 1.99-1.86(\mathrm{~m}, 2 \mathrm{H}), 1.77(\mathrm{~m}, 1 \mathrm{H}), 1.62(\mathrm{~m}, 1 \mathrm{H})$. ${ }^{13} \mathrm{C} \mathrm{NMR}\left(125 \mathrm{MHz}, \mathrm{CDCl}_{3}\right) \delta 166.73,159.23,156.27,130.06,129.36$ (2 C), 114.96, 113.83 (2 C), 78.59, 76.90, 73.09, 72.63, 61.28, 55.26, 51.04, 42.44, 37.77, 31.95. Anal calcd for $\mathrm{C}_{19} \mathrm{H}_{26} \mathrm{O}_{5}$ : C, 65.13\%; H, 7.48\%. Found: C, 65.30\%; H, 7.61\%.

\footnotetext{
${ }^{1}$ Tasuno, Y.; Toshida, T.; Otsuka, S. Inorg Synth. 1979, 19, 220

${ }^{2}$ Ukai, T.; Kawazura, H.; Iishii, Y.; Bonnett, J; Ibers, J. A.; J. Organomet. Chem. 1974, 65, 263.

3 (a) Trost, B. M.; Van Vranken, D. L. Angew. Chem. Int. Ed. 1992, 31, 228. (b). Trost, B. M.; Van Vranken, D. L. J. Am. Chem. Soc. 1992, 114, 9327.

${ }^{4}$ Trost, B. M.; Older, C. M. Organometallics 2002, 21, 2544.

${ }^{5}$ Still, W. C.; Kahn, M.; Mitra, J. A. J. Org. Chem. 1978, 48, 2923.

${ }^{6}$ Boeckman, R. K. Jr.; Potenza, J. C. Tetrahedron Lett. 1985, 26, 1411.

${ }^{7}$ Fox, M. E.; Marino, J. P.; Overman, L. E. J. Am. Chem. Soc. 1999, 121, 5467.

${ }^{8}$ Haack, K.-J.; Hashiguchi, S.; Fujii, A.; Ikariya, T.; Noyori, R. Angew. Chem., Int. Ed. 1997, $36,285$.

${ }^{9}$ Jacobsen, E. N. Acc. Chem. Res. 2000, 33, 421.

${ }^{10}$ Savle, P. S.; Lamoreaux, M. J.; Berry, J. F.; Gandour, R.D. Tetrahedron Asymm. 1998, 1843.

${ }^{11}$ Patel, D. V.; VanMiddlesworth, F.; Donaubauer, J.; Gannett, P.; Sih, C. J. J. Am. Chem. Soc. 1986, 108, 4603.

${ }^{12}$ Barraclough, P.; Hudhomme, P.; Spray, C. A.; Young, D. W. Tetrahedron 1995, 51, 4195.

${ }^{13}$ Chatterjee, A.K.; Sanders, D. P.; Grubbs, R. H. Org. Lett. 2002, 4, 1939.

${ }^{14}$ Oda, H.; Sato, M.; Morizawa, Y.; Oshima, K.; Nozaki, H. Tetrahderon Lett. 1983, 24, 2877.

${ }^{15}$ Ohloff, G.; Giersch, W.; Schulte E.; Karl, H.; Enggist, P.; Demoule, E. Helv. Chim. Acta 1980, 63, 1582.

${ }^{16}$ Miyazawa, M.; Katsuyuki, Y.; Kameoka, H. Phytochemistry 1995, $39,85$.

${ }^{17}$ O’Neil, S. V.; Quickley, C. A.; Snider, B.B. J. Org. Chem. 1997, 62, 1970.

${ }^{18}$ Powell, N. A.; Roush, W. R. Org. Lett. 2001, 3, 453.

${ }^{19}$ Known compound (Tsuboi, S.; Takeda, S.; Yamasaki, Y.; Sakai, T.; Utaka, M. Chem. Lett. 1992, 8, 1417) formed from glycidol epoxide, $\mathrm{NaH}$, and $\mathrm{PMBCl}$.
} 